ISSN 2067-4082 e-ISSN 2068-9969

L-ISSN 2067-4082

\section{Journal of Urban}

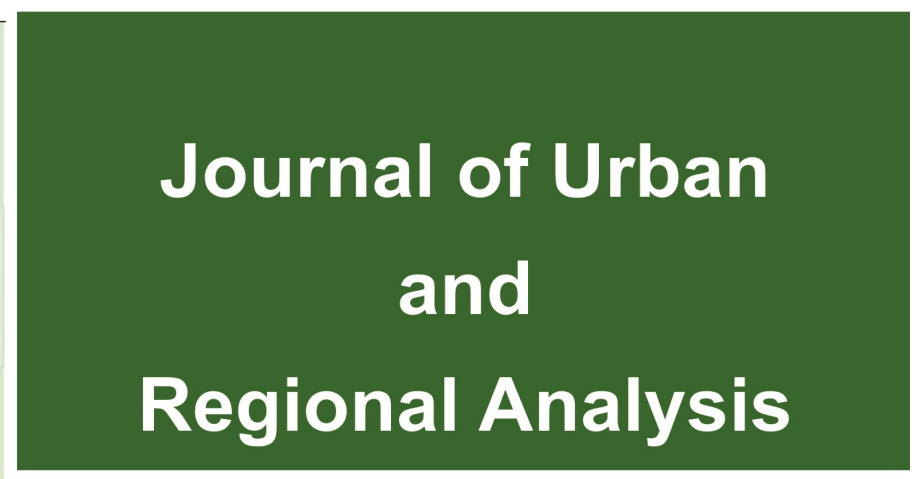

Volume XI - Issue 1 - June, 2019

\title{
CONTENTS
}

Maria Teresa CIOMMI, Ilaria ZAMBON, Luca SALVATI PopulationDynamics, Agglomeration Economies and Municipal Size: a Long-Term Analysis

Lucian VESALON, Remus CRETAN - "Little Vienna " or " European Avant-Garde City ? "Branding Narratives in a Romanian City

Monika Maria CYSEK-PAWLAK - Testing the New Urbanism Principle of Sustainable Transport in the Contemporary

Redevelopment Projects. Lessons from Clichy - Batignolles in Paris and the Station Area of Lodz

Rini RACHMAWATI, Nur Mohammad FARDA, R. RIJANTA, Bowo SETIYONO - The Advantages and Analysis of the Location of Branchless Baking in Urban and Rural Areas in Yogyakarta Special Region, Indonesia

Viorel MIONEL - From Religious Segregation to Cultural Heritage. The Case of the Armenian Community in Bucharest

Kenichi SHIMAMOTO - Empirical Analysis on the Determinants of Urban Parks

BOOK REVIEWS 
Regional Analysis

Ioan IANOŞ, University of Bucharest

\section{EDITORS}

\author{
Urban Analysis \\ Ronan PADDISON, University of Glasgow
}

Managing Editors:

Cristian TĂLÂNGÃ, University of Bucharest

Mirela PARASCHIV, "Ovidius" University of Constanța

EDITORIAL BOARD

Jerzy BANंSKI

Polish Academy of Sciences, Poland Gerhard BRAUN

Free University of Berlin, Germany Wilfried HELLER

University of Potsdam, Germany Roy JONES

Curtin University, Bentley, Australia Peter JORDAN

University of Vienna, Austria Audrey KOBAYASHI

Queen's University, Kingston, Canada

Ruben Camilo Lois GONZALEZ

University of Santiago de Compostela, Spain
George POMEROY

University of Shippensburg, USA Denise PUMAIN

Paris University 1, France Michael SOFER

Bar-Ilan University, Israel Izhak SCHNELL

Tel Aviv University, Israel Anthony SORENSEN

University of New England, Armidale, Australia Alexandru UNGUREANU

"Al.I.Cuza" University, laşi, Romania Jan WENDT

University of Gdansk, Poland

\section{INTERNATIONAL EDITORIAL ADVISORY BOARD}

\section{Jozsef BENEDEK}

"Babes-Bolyai" University, Cluj-Napoca, Romania Joan Serafi BERNAT

Jaume I University, Castelló, Spain

David BOLE

Anton Melik Geographical Institute, Slovenia Cristian BRAGHINĂ

University of Bucharest, Romania Milan BUFON

University of Primorska, Slovenia Hans-Joachim BÜRKNER

University of Potsdam, Germany Pompei COCEAN

"Babess-Bolyai" University, Cluj-Napoca, Romania Joaquin FARINOS DASI

University of Valencia, Spain Hermanus S. GEYER

Stellenbosch University, South Africa Daniel GÖLER

University of Bamberg, Germany Octavian GROZA

"Al.I.Cuza" University, laşi, Romania Lisa HARRINGTON

Kansas State University, USA Alexandru ILIEŞ

University of Oradea, Romania Margarita ILIEVA

Kazimierz Wielki University, Poland lonel MUNTELE

"Al.I.Cuza" University, laşi, Romania Gabriel PASCARIU

"Ion Mincu" University of Architecture and Urbanism, Bucharest, Romania

\section{Valeria PAUL}

University of Santiago de Compostela, Spain Alexandru-lonuţ PETRIŞOR

"Ion Mincu" University of Architecture and

Urbanism, Bucharest, Romania Victor PLATON

Institute of National Economy, Bucharest, Romania Petr RUMPEL

University of Ostrava, Czech Republic Alexandru SANDU

"Ion Mincu" University of Architecture and Urbanism, Bucharest, Romania Dumitru SANDU

University of Bucharest, Romania Cătălin SÂRBU

"Ion Mincu" University of Architecture and Urbanism, Bucharest, Romania Andrei SCHVAB

"Ovidius" University of Constanța, Romania Igor SîRODOEV

Moldavian Academy of Sciences, Rep. of Moldova Izhak SCHNELL

Tel Aviv University, Israel Vasile SURD

"Babes-Bolyai" University, Cluj-Napoca, Romania Rafael VIRUELA

University of Valencia, Spain George WHITE

South Dakota State University, USA UIf WIBERG

Umeå University, Sweden Daniela ZAMFIR

University of Bucharest, Romania

The manuscripts and exchange reviews, as well as, any correspondence will be sent on the Editorial Office:

University of Bucharest - Interdisciplinary Centre for Advanced Researches on Territorial Dynamics 030018, 4-12, Regina Elisabeta Blv., Bucharest, Romania

Tel/fax: 0040213138 410, e-mail: office@cicadit.ro, http://www.jurareview.ro 


\title{
Journal of Urban and Regional Analysis
}

\author{
Volume XI - Issue 1 - June, 2019
}

\author{
Journal indexed in: \\ CLARIVATE ANALYTICS - EMERGING SOURCES CITATION INDEX \\ SCOPUS \\ EBSCO \\ CENTRAL \& EASTERN EUROPEAN ACADEMIC SOURCE DATABASE \\ COVERAGE LIST \\ PROQUEST SCITECH JOURNALS \\ ULRICHSWEB \\ DIRECTORY OF OPEN ACCESS JOURNALS (DOAJ) \\ INDEX COPERNICUS INTERNATIONAL \\ KNOWLEDGE BASE SOCIAL SCIENCES EASTERN EUROPE (GESIS)
}

University of Bucharest 
TECHNICAL BOARD

University of Bucharest - Interdisciplinary Centre for Advanced Research on Territorial Dynamics

Electronic editing and cover: Cristian TĂLÂNGĂ

\section{Book reviews editors:}

Daniela ZAMFIR

Andreea Loreta CERCLEUX

Electronic mapping:

Florentina Cristina MERCIU
Documentary:

Ilinca Valentina STOICA

Maria Nataşa VAIDIANU-TĂTUI

Correction:

Alexandru-lonut PETRISTOR Irina SAGHIN-FLOREA'

Correspondence:

George SECĂREANU

The review is issued under the aegis and the support of the University of Bucharest - Interdisciplinary Centre for Advanced Research on Territorial Dynamics

www.jurareview.ro 
Journal of Urban and Regional Analysis, vol. XI, 1, 2019

\section{CONTENTS}

- Maria Teresa CIOMMI, Ilaria ZAMBON, Luca SALVATI - Population Dynamics, Agglomeration Economies and Municipal Size: a LongTerm Analysis

- Lucian VESALON, Remus CREȚAN - " Little Vienna " or " European Avant-Garde City ? "Branding Narratives in a Romanian City

- Monika Maria CYSEK-PAWLAK - Testing the New Urbanism Principle of Sustainable Transport in the Contemporary Redevelopment Projects. Lessons from Clichy - Batignolles in Paris and the Station Area of Lodz

- Rini RACHMAWATI, Nur Mohammad FARDA, R. RIJANTA, Bowo SETIYONO - The Advantages and Analysis of the Location of Branchless Baking in Urban and Rural Areas in Yogyakarta Special Region, Indonesia

- Viorel MIONEL - From Religious Segregation to Cultural Heritage. The Case of the Armenian Community in Bucharest

- Kenichi SHIMAMOTO - Empirical Analysis on the Determinants of Urban Parks

- Book Reviews 


\title{
POPULATION DYNAMICS, AGGLOMERATION ECONOMIES AND MUNICIPAL SIZE: A LONG-TERM ANALYSIS
}

\author{
Maria Teresa CIOMMI ${ }^{1}$, Ilaria ZAMBON ${ }^{2}$, Luca SALVATI ${ }^{3,4}$ \\ ${ }^{1}$ Università Politecnica delle Marche, Ancona, Italy; ${ }^{2}$ Tuscia University, Viterbo, Italy; \\ ${ }^{3}$ Consiglio per la Ricerca in agricoltura e l'analisi dell'Economia Agraria (CREA), \\ Arezzo, Italy; ${ }^{4}$ University of Rome 'La Sapienza', Rome, Italy
}

\begin{abstract}
Under the hypothesis that modifications in municipal boundaries and creation (or suppression) of new administrative units reflect a progressive adjustment toward a more balanced distribution of population over space, the present study investigates the long-term relationship (1928-2012) between urban expansion, population dynamics and municipal area in a growing metropolitan region (Athens, Greece). In expanding regions, municipal size is a key variable outlining the amount and spatial concentration of services and infrastructures, resulting to be functionally related to population density, agglomeration factors, land availability to building and characteristic socioeconomic profiles of local communities. A statistical analysis of the relationship between population density and municipal area provides basic knowledge to policy and planning adjustments toward a more balanced spatial distribution of population and land among the local government units. Descriptive statistics, mapping, correlation analysis and linear regressions were used to assess the evolution of such relationship over a sufficiently long time period. The average municipal area in Athens decreased moderately over time, with a slight increase in spatial heterogeneity. Conversely, the average population density per municipality increased more rapidly, with a considerable reduction in spatial heterogeneity. The observed goodness-of-fit of the linear relationship between population density and municipal area increased significantly over time. The empirical results of our study indicate that municipal size has progressively adjusted to population density across metropolitan areas, determining a more balanced spatial distribution of the resident population, which was consolidated by the recent administrative reform of the local authorities in Greece (the so called 'Kallikratis' law). Such conditions represent a base for the informed analysis of the spatial structure of local administrative units and they contribute to the debate on the optimal size of municipalities and other administrative districts with relevant impact on both urban and metropolitan scales of governance.
\end{abstract}

Key Words: administrative domain, local development, urban growth, population density, Europe.

\section{Introduction}

Diseconomies of scale associated with larger governments requiring proportionally more administration are a particularly relevant issue in political science under fragmented territories and increasing competitiveness among local contexts (Dollery and Crase 2004, Schneider and Woodcock 2008, Andrews and Boyne 2009, Lassen and Serritzlew 2011, Tavares and Rodrigues 2015, Dhimitri 2018). With optimal jurisdiction size being a cornerstone in government design, a long-established tradition in political thought argues that democracy and governance efficiency thrive in smaller administrative units. In the last decades, municipal amalgamation has accounted for a substantial reduction in the number of councils in several countries worldwide (e.g. Australia: Dollery and Crase 2004; Switzerland: Steiner 2003; Canada: Keil and Boudreau 2005; but see also Allan 2003). Theories supporting programs of municipal consolidation argue that important economic benefits will flow from fewer and larger 
municipal councils. Based on the Australian experience in the 1990s, where amalgamation programs resulted in an evident decrease in the number of local administrative units, Byrnes and Dollery (2002) evaluated the validity of the assumption that larger municipalities would exhibit greater economic efficiencies. The literature review and empirical results from that study specified that this argument did not derive from an effective and solid empirical base. In other welfare systems, such as those adopted in northern European countries, unique systems of highly decentralized municipalities were historically promoted and maintained over time (UNHABITAT 2009). However, a discussion about merging municipalities has more recently emerged, e.g. in Denmark (Larsen 2002). While, non-electoral participation resulted to be higher in small municipalities, municipal size seems to be neutral in term of citizens' interest in (and knowledge of) local politics. This evidence shed further light on the classical framework of the dichotomy between capacity and proximity, linking empirical findings to more general considerations about administrative effectiveness versus democracy and citizens' participation to public choice. Lassen and Serritzlew (2011: 238) found different results from a quasiexperiment based on a large-scale municipal reform in Denmark, that allowed estimating a causal effect of administrative unit's size on internal political efficacy: "Jurisdiction size has a causal and sizeable detrimental effect on citizens' internal political efficacy". In other words, as suggested by Rose (2002: 829), the effect of size "is not merely a by-product of the compositional characteristics of the individual living in different sized municipalities". However, while it is reasonable to expect size to be relevant, the nature of the relationship may vary from one form of participation to another. In Norway, the central government has recently designed a framework to consolidate municipalities based on a voluntary program. Based on this context, Sørensen (2006) tested if political transaction costs will hinder associations, analysing some efficiency and cost proposition built on spatio-temporal data for Norwegian local authorities (Holzer et al. 2009). Reforms, especially those affecting a partial ensemble of municipalities in a region, often result in exogenous - and substantial - changes in municipal population size with uncertain impact on governance efficiency (Bel and Warner 2015).

Growing scepticism in policy circles over the efficacy of municipal consolidation as a suitable method of enhancing the operational efficiency of local councils was reported, e.g. for Australia (Dollery et al. 2007). Apart from large amalgamation programs, a range of promising alternative options was proposed "that may be able to effectively combine more efficient service delivery with vibrant local democracy" (Dollery and Johnson 2005: 73). Concerning local democracy, Keil and Boudreau (2005) discussed the establishment of more moderately liberal and social democratic administrations in some regions of Canada during the 1990s, highlighting the role of social movement demands in the revision of municipal government mechanisms. In this line of thinking, Steiner (2003: 551) found that "reform-friendly authorities, intensive social contacts among the inhabitants of the municipalities, a favourable topographic location and the policies of the superordinate government level promote enthusiasm for reforms".

By estimating the cost of providing local government services, Carey et al. (1996) introduced the notion of the 'optimal' size of administrative units, e.g. municipalities. Based on empirical models, the optimal number of administrative districts for a fixed population size in each region was identified under the assumption that the geographic aggregation of municipalities into larger and denser municipal districts will reduce the costs of public services. However, although policymakers believe that larger municipalities exhibit greater efficiency, evidences are mixed about the relationship between population density and municipal efficiency (Holzer et al. 2009). While larger municipalities with a population over 250000 are clearly less efficient, there is also little correlation between size and efficiency for municipalities with populations between 25000 and 250000 people; moreover, while the literature suggests that smaller municipalities are less efficient - outlining important deviations from this general pattern at the same time - small municipalities are demonstrated to be largely efficient in specialized services (Dhimitri 2018).

When evaluating the impact of jurisdiction size on various 'optimal' socioeconomic criteria, 
ambiguous results emerged due to several reasons, including sorting effects, data endogeneity and the lack of dedicated experiments simulating the impact of policy reforms. Moreover, by contributing to the broader issue of 'optimal city size' (Singell 1974), Capello and Camagni (2000) discussed on the notion of administrative local units' optimal size, concentrating to the concept of the 'efficient size' of a municipality or a city, based on the functional characteristics of the given spatial unit and on its spatial organization within the urban system. In this sense, processes of transformation in regional economic structures with intense population mobility (e.g. within metropolitan regions), and possibly reflected in multiple, subsequent reforms of local authorities (increasing or reducing the number and size of municipalities), may represent specific conditions under which to indirectly evaluate the controversial question of economies of scale in the local government. In a framework of widespread expansion of both state and regional planning programs, Carruthers and Ulfarsson (2002) examined the relationship between governmental fragmentation and urban development, outlining the emergent need to promote jurisdictional cooperation and regulatory consistency across metropolitan regions.

The present study contributes to this deserving issue by investigating the multiple relationships between urban expansion, agglomeration factors, population density and municipal size in a European metropolitan region - Athens, Greece - rapidly expanding between 1928 and 2012. The transformations in municipal boundaries with the creation (or suppression) of new administrative units were hypothesized to reflect a progressive adjustment toward a more balanced distribution of population over space (Salvati et al. 2013). Since municipal size is a relevant variable reflecting the amount of services and infrastructures - being functionally related with both population concentration and land availability to building in expanding metropolitan regions (Carruthers and Ulfarsson 2002, Salvati and Gargiulo Morelli 2014, Pili et al. 2017, Cecchini et al. 2018, Duvernoy et al. 2018, Wolff et al. 2018) - a quantitative analysis of the relationship between population density and municipal area is supposed to provide basic knowledge for the identification of the local administrative units' optimal size (Dhimitri 2018).

\section{Methodology}

Study area

The Athens Metropolitan Region extends nearly $3000 \mathrm{~km}^{2}$ in the administrative region of Attica in Greece, coinciding with the functional boundaries of the 'Urban Atlas' region of Athens, the capital of Greek Republic. All mainland municipalities, including those belonging to Salamina island, are considered in the study area. While the regional territory mostly consists of mountains bordering the flat area around Athens' inner city, three coastal plains (Messoghia, Marathona, Thriasio) concentrated population commuting to the urban area of Athens-Piraeus (Salvati and Serra 2016). Our analysis covers a time frame of more than 80 years between 1928 and 2012, including sequential expansion waves of Athens, fuelled by increasing population flows from Asia Minor after the 1921 War, rural-urban migration in the aftermath of World War II, natural increase driven by growing fertility and declining mortality patterns typical of the 1960s and the 1970s, as well as increasing migration flows (both internal and international) afterwards (Couch et al. 2007).

In this study, we used Greek municipalities as basic territorial entities with a degree of administrative autonomy and dedicated to the interests of local populations; the capital city (Athens) is governed by a specific municipality. In urban and regional studies, municipalities are frequently used as basic units of analysis. In addition to municipalities, there is also the entity of metropolitan areas, which bring together many municipalities. As the metropolitan area of Athens, a metropolitan area defines an agglomeration (or conurbation) which, for its various services and activities, depends on the central city (in this case, Athens) and it is characterized by the integration of its functions and the intensity of its relations regarding economic activities, services, cultural and territorial characteristics. Additional elements supporting a metropolitan 
area are the presence of a transport network connecting the different urban areas and the presence of intense social interactions within the area.

In this paper, we analysed two quasi-experiments in terms of municipal restructuring (Hlepas 2010, Ladi 2014, Featherstone 2015): (i) the progressive increase in the number of municipal units under the same general spatial framework (based on the traditional spatial asset of municipalities in Greece, consolidated with the more recent 'Kapodistrias' organization structure; this structure was adapted to manage intense population growth and massive urban expansion into rural areas (between 1928 and 2011) and it resulted in a partition of the study region into more than 100 administrative domains (Fig. 1); and (ii) a more recent reform of local government units (2011), the so called 'Kallikratis' law approved by the Greek parliament and reducing the number of municipalities to nearly 60 in the study area (Hlepas and Getimis 2011, Colantoni et al. 2016a, 2016b, Rontos et al. 2016). Fig. 2 illustrates the temporal period with maximum urban concentration for each municipality, based on the vertical profile of buildings. Descriptive statistics, correlation analysis and linear regressions were used to evaluate such relationships over time, informing on the political and planning adjustments to a more balanced spatial distribution of population and land among the local government units.

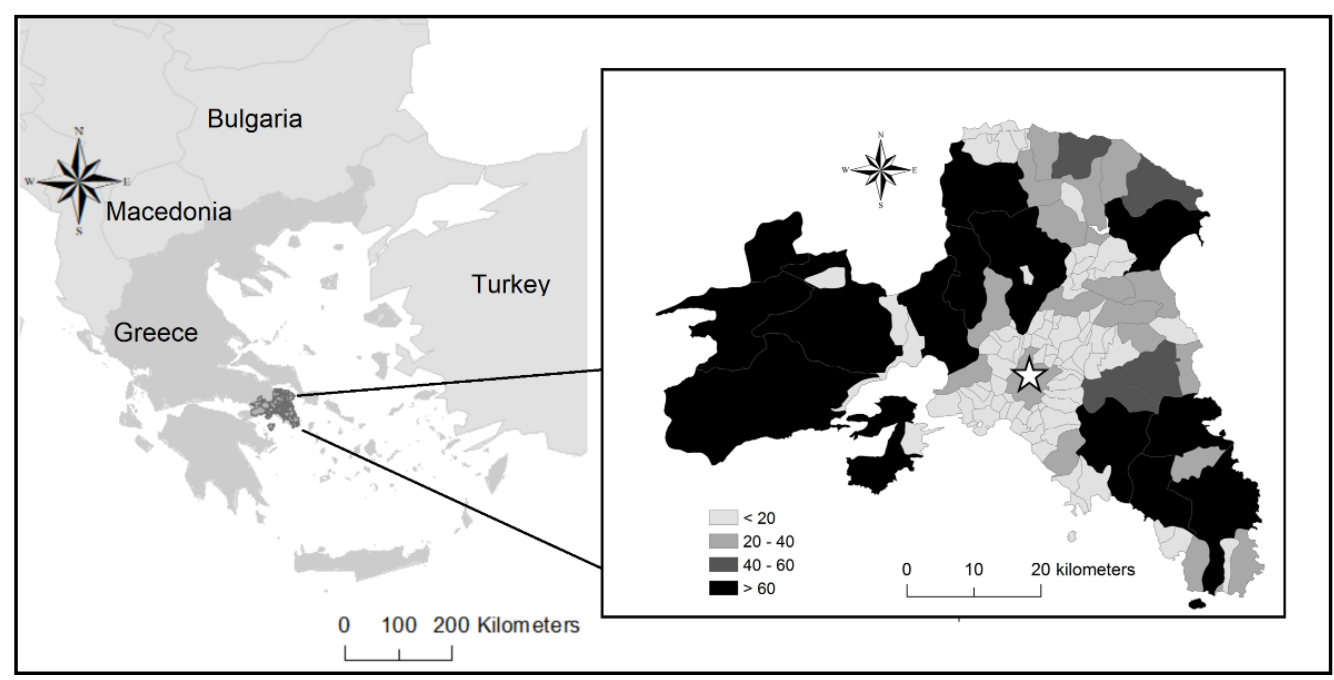

Fig. 1 - Boundaries and size $\left(\mathrm{km}^{2}\right)$ of municipalities belonging to Athens' metropolitan region in 2011

Source: traditional spatial organization of local authorities (the star indicates the downtown of Athens)

\section{Indicators}

Municipal area $\left(\mathrm{km}^{2}\right)$ and population size (total resident inhabitants) were derived from the National Population Census held by the National Statistical Service of Greece (NSSG, now ELSTAT) approximately every 10 years (1928, 1940, 1951, 1961, 1971, 1981, 1991, 2001 and 2011). The population density per municipality was calculated based on these data. A vector map of municipalities provided by ELSTAT was used to illustrate the spatial distribution of the studied variables. The relationship between population density and municipal size was illustrated in Fig. 3; the scatterplot evidenced a logarithmic form that distinguishes urban municipalities (small size and high population density) from rural municipalities (large size and low population density). 


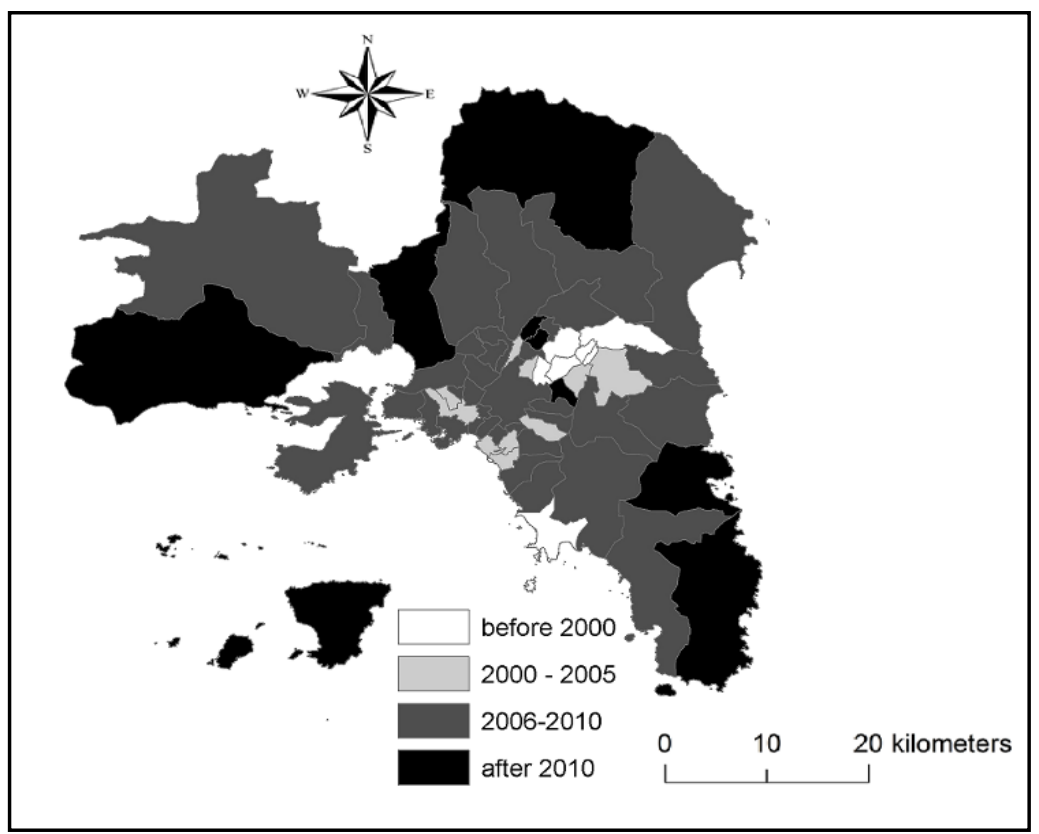

Fig. 2 - Boundaries of municipalities belonging to Athens' metropolitan region in 2012 Source: 'Kallikratis' reform of local authorities in Greece, illustrating the temporal period with maximum urban concentration based on the vertical profile of buildings
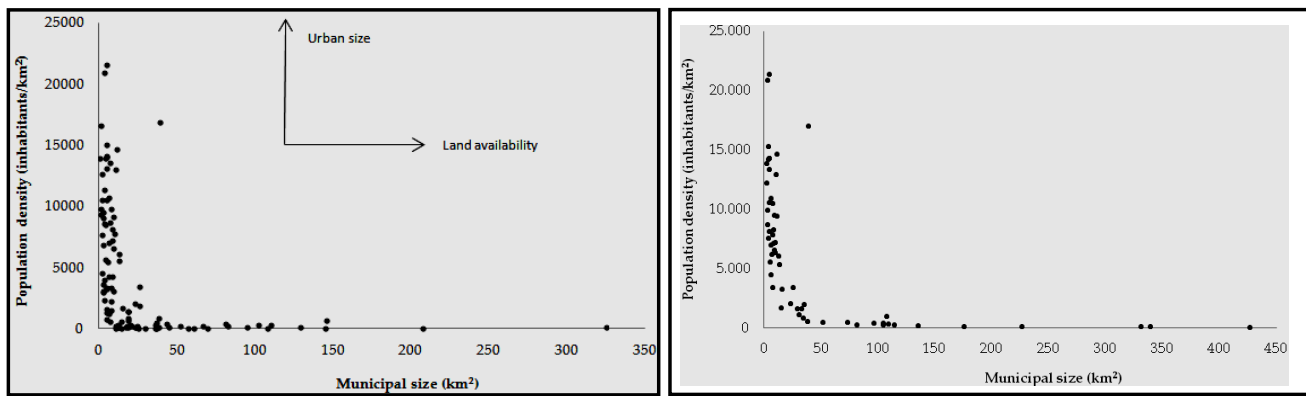

Fig. 3 - Scatterplots illustrating the relationship between population density and municipal size (left: 'Kapodistrias' spatial organization; right: 'Kallikratis' reform of local authorities) in the study area (2011 population data), evidencing agglomeration factors (urban size) and rural dimension (land availability)

\section{Statistical analysis}

Under the hypothesis that municipal size is negatively correlated with population density, the present study proposes a comprehensive approach to evaluate the implications of this relationship in terms of optimal municipal size, using time series population data covering a sufficiently long temporal period (60 years), from 1951 to 2011. Considering the logarithmic relation between population density and municipal size illustrated above, a log-log correlation 
analysis between population density and municipal size in the study area was run to assess changes in correlation with regime over time. Three correlation coefficients, using both parametric (Pearson) and non-parametric (Spearman and Kendall) techniques, were tested with the final objective to identify both linear and non-linear relationships between the two variables. The similar values in the three correlation coefficients indicate a linear relationship between variables. Based on these findings, a linear regression model was run using log (municipal size) as dependent variable and log (population density) as independent variable separately for each year of investigation (from 1928 to 2012). Slope coefficients and intercepts, together with the respective adjusted- $R^{2}$, were analysed as the model's output. The ratio between slope and intercept was computed for each time point with the aim to evaluate the changes over time in the spatial structure of the relationship between the two variables. For the two selected years (1928 and 2011), based on the traditional spatial asset of local units, different polynomial models (from grade 2 to 6 ) regressing log (municipal size) to log (population density) were run with the final objective to demonstrate that a linear form is the best descriptor of the relationship mentioned above. Percent increases in the $R^{2}$ with rising equation grade (e.g. from grade 1 - linear form - to grade 2 - square relation) were computed separately for models referring to 1951 and 2011.

\section{Results}

The number of municipalities increased slightly in the Athens' metropolitan region during the study period (Table 1). Based on the traditional spatial asset of local governance units, the median municipal size decreased moderately from $13 \mathrm{~km}^{2}$ to nearly $9 \mathrm{~km}^{2}$, with an increasing spatial variability. The median population stock per municipality increased considerably because of inherent processes of urban growth. Consequently, the median density of resident population increased over time with an evident decrease in spatial variability. The 'Kallikratis' spatial asset of local authorities resulted in a consolidation of previous trends in municipal area and population distribution, with larger municipal size $\left(11.2 \mathrm{~km}^{2}\right)$ and resident population (median per municipality) three-time higher than the precedent spatial asset.

Table 1

Municipal size, absolute population and population density in the Athens' metropolitan region, by year (1928-2012)

\begin{tabular}{|c|c|c|c|c|c|c|c|}
\hline \multirow{2}{*}{ Year } & \multirow{2}{*}{$\frac{\text { No }}{\text { municip. }}$} & \multicolumn{2}{|c|}{$\begin{array}{c}\text { Municipal size } \\
\left(\mathrm{km}^{2}\right)\end{array}$} & \multicolumn{2}{|c|}{$\begin{array}{l}\text { Absolute population } \\
\text { (inhabitants) }\end{array}$} & \multicolumn{2}{|c|}{$\begin{array}{l}\text { Population density } \\
\left(\text { inh. } / \mathrm{km}^{2}\right)\end{array}$} \\
\hline & & Median & $\mathrm{CV}$ & Median & $\mathrm{CV}$ & Median & $\mathrm{CV}$ \\
\hline 1928 & 96 & 13.4 & 1.5 & 1,313 & 4.5 & 57 & 2.9 \\
\hline 1940 & 103 & 12.0 & 1.6 & 2,231 & 4.1 & 140 & 2.2 \\
\hline 1951 & 105 & 10.7 & 1.6 & 3,305 & 4.0 & 214 & 2.0 \\
\hline 1961 & 109 & 10.5 & 1.6 & 5,503 & 3.4 & 331 & 1.7 \\
\hline 1971 & 112 & 9.8 & 1.6 & 7,812 & 3.4 & 544 & 1.5 \\
\hline 1981 & 115 & 9.5 & 1.6 & 10,100 & 2.9 & 637 & 1.4 \\
\hline 1991 & 115 & 9.5 & 1.6 & 12,023 & 2.5 & 1235 & 1.3 \\
\hline 2001 & 115 & 9.5 & 1.6 & 13,921 & 2.3 & 1401 & 1.3 \\
\hline 2011 & 115 & 9.5 & 1.6 & 16,002 & 2.0 & 1717 & 1.2 \\
\hline $2012^{*}$ & 59 & 11.2 & 1.7 & 46,897 & 1.3 & 6072 & 0.9 \\
\hline
\end{tabular}

Statistical figures include median and CV, Coefficient of variation;

*indicates a time point referring to the 'Kallikratis' spatial asset. 
The empirical relationship between log (municipal size) and log (population density) in the Athens' metropolitan region was illustrated in Fig. 4 for the first and the last points in time considered in this study, using the same spatial asset ('Kapodistrias' municipalities). The relation was linear at the end of the study period (2011) and more scattered at the beginning of the study period (1951).
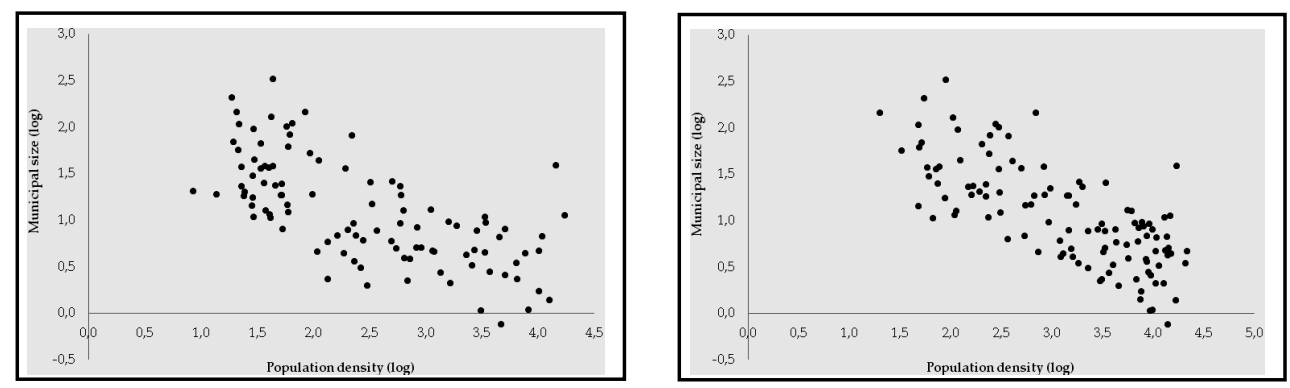

Fig. 4 - A log-log scatterplot illustrating the relationship between municipal area ('Kapodistrias' spatial asset) and population density, in 1951 (left) and 2011 (right), in the study area

Table 2 reports the main results of a correlation analysis between log (municipal area) and log (population density) or log (population stock) based on three (parametric and non-parametric) correlation coefficients. As far as population stock is concerned, all tested correlations were statistically not significant $(p>0.05)$ for all investigated years and correlation techniques, possibly indicating a substantial independence between population size and municipal size (the correlation coefficients are available on request). Concerning the population density, all coefficients were characterized by a comparable pattern, increasing over time to a peak observed at the end of the study period. All correlation coefficients were negative and significant at $p<0.001$.

Regressions indicate an increasing goodness-of-fit of the linear model predicting municipal size on the base of population density (Table 3 ). Adjusted- $R^{2}$ increased over time from 0.25 to 0.87 ; however, this increase followed a U-shaped pattern with the lowest value observed for 1971, in parallel with the highest urban concentration in the study area (Salvati et al. 2016). Slope-tointercept ratio indicated a substantial break-point in the investigated time series during the 1970s, corroborating the results presented above. The regression results referring to the new spatial asset ('Kallikratis') were in line with the earlier evidence, indicating a substantial consolidation of previous trends in both slope and intercept. For instance, the rapid (negative) increase of slope for 'Kallikratis' asset is in line with the less intense, long-term increases observed since 1981 and paralleling the de-centralized metropolitan growth typical of the study area.

Table 4 reports the percent improvement in goodness-of-fit (based on the adjusted $\mathrm{R}^{2}$ metric) of models predicting municipal size from population density that use polynomial functional forms of variable grade from 2 to 6 . Percent improvement in the $\mathrm{R}^{2}$ goodness-of-fit using different polynomial models was calculated separately for the two selected years (1951 and 2011) based on the same spatial asset of local municipalities. This time period was considered rather homogeneous in term of mechanisms of urban growth and spatial structure. Although modest increases were observed for both years - thus validating a linear form between municipal size and population density in the study area - the $\mathrm{R}^{2}$ percent improvement was systematically higher for all polynomial grades when applied to 1951 data than for 2011 data. 
This evidence is in line with the descriptive analysis, outlining a less scattered distribution of observations in 2011 than in 1951.

Table 2

Correlation analysis (left) between municipal area (log) and absolute population (log) or population density (log) using both parametric (Pearson) and non-parametric (Spearman and Kendall) coefficients, by year (1928-2011)

\begin{tabular}{|l|l|c|c|c|}
\hline \multirow{2}{*}{ Year } & \multicolumn{3}{|c|}{ Population density } \\
\cline { 2 - 4 } & & Pearson & Spearman & Kendall \\
\hline 1928 & $-0.59^{*}$ & $-0.54^{*}$ & $-0.37^{*}$ \\
\hline 1940 & & $-0.66^{*}$ & $-0.66^{*}$ & $-0.46^{*}$ \\
\hline 1951 & & $-0.69^{*}$ & $-0.71^{*}$ & $-0.50^{*}$ \\
\hline 1961 & & $-0.73^{*}$ & $-0.69^{*}$ & $-0.49^{*}$ \\
\hline 1971 & & $-0.73^{*}$ & $-0.69^{*}$ & $-0.48^{*}$ \\
\hline 1981 & & $-0.75^{*}$ & $-0.69^{*}$ & $-0.48^{*}$ \\
\hline 1991 & & $-0.75^{*}$ & $-0.73^{*}$ & $-0.51^{*}$ \\
\hline 2001 & & $-0.77^{*}$ & $-0.74^{*}$ & $-0.53^{*}$ \\
\hline 2011 & & $-0.77^{*}$ & $-0.74^{*}$ & $-0.52^{*}$ \\
\hline $2012^{* *}$ & $-0.94^{*}$ & $-0.85^{*}$ & $-0.71^{*}$ \\
\hline
\end{tabular}

*significant at $p<0.05$; *indicates a time point referring to the 'Kallikratis' spatial asset

Table 3

Results of linear regression (right) with municipal area (log) as dependent variable and population density (log) as predictor in the Athens' metropolitan region, by year (1928-2011)

\begin{tabular}{|l|c|c|c|c|c|c|c|}
\hline Year & & Intercept & Slope & Slope/Interc & Adj-R & df & Durbin-W. \\
\hline 1928 & & $1.83(0.13)$ & $-0.34(0.06)$ & -0.18 & $0.25^{*}$ & $1 ; 94$ & 1.62 \\
\hline 1940 & & $2.06(0.13)$ & $-0.41(0.05)$ & -0.20 & $0.37^{* *}$ & $1 ; 101$ & 1.63 \\
\hline 1951 & & $2.14(0.12)$ & $-0.42(0.04)$ & -0.20 & $0.46^{* *}$ & $1 ; 103$ & 1.63 \\
\hline 1961 & & $2.12(0.11)$ & $-0.40(0.04)$ & -0.19 & $0.46^{* *}$ & $1 ; 107$ & 1.57 \\
\hline 1971 & & $2.14(0.11)$ & $-0.39(0.04)$ & -0.18 & $0.47^{* *}$ & $1 ; 110$ & 1.52 \\
\hline 1981 & & $2.22(0.12)$ & $-0.40(0.04)$ & -0.18 & $0.48^{* *}$ & $1 ; 113$ & 1.50 \\
\hline 1991 & $2.42(0.12)$ & $-0.45(0.04)$ & -0.19 & $0.53^{* *}$ & $1 ; 113$ & 1.61 \\
\hline 2001 & & $2.56(0.13)$ & $-0.49(0.04)$ & -0.19 & $0.55^{* *}$ & $1 ; 113$ & 1.66 \\
\hline 2011 & & $2.60(0.13)$ & $-0.49(0.04)$ & -0.19 & $0.56^{* *}$ & $1 ; 113$ & 1.70 \\
\hline 2012 & & $3.98(0.14)$ & $-0.79(0.04)$ & -0.20 & $0.87^{* *}$ & $1 ; 57$ & 1.70 \\
\hline
\end{tabular}

Df-degrees of freedom; Durbin-W. - Durbin-Watson statistics; Intercept's and slope's errors in brackets; Significant coefficient at ${ }^{*} p<0.05$ or ${ }^{* *} p<0.001$; The italics indicates data referring to the 'Kallikratis' spatial asset

Table 4

Per cent gain in the adjusted- $R^{2}$ goodness-of-fit of the relationship between municipal area and population density with the use of polynomial equations of increasing grade following Kapodistrias spatial asset of local units (selected years: 1951 and 2011)

\begin{tabular}{|l|c|c|}
\hline Grade & 1951 & 2011 \\
\hline 2 vs 1 & 5.1 & 0.2 \\
\hline 3 vs 2 & 4.4 & 1.4 \\
\hline 4 vs 3 & 0.2 & 1.6 \\
\hline 5 vs 4 & 3.6 & 0.5 \\
\hline 6 vs 5 & 0.8 & 0.1 \\
\hline
\end{tabular}




\section{Discussion}

Based on the inherent evolution of agglomeration factors, recent spatial changes in population structures reflect distinctive urbanization processes occurring in several European large- and medium-size cities, and causing a spatial (re)balancing of activities and population deconcentration (Kasanko et al. 2006, Longhi and Musolesi 2007, Carlucci et al. 2017, CuadradoCiuraneta et al. 2017, Zambon et al. 2018). By investigating the latent relationship between population density and municipal area in a European metropolitan region expanding in the last 60 years, our study has contributed to a multi-criteria assessment of optimal municipal size (Serra et al. 2014, Zitti et al. 2015, Salvati et al. 2017, Pili et al. 2017). Under the assumption that changes in municipal boundaries (with creation/suppression of new administrative units) are associated with progressive adjustments toward a more balanced distribution of population over space (Carruthers and Ulfarsson 2002), the relationship between municipal size and population density was considered a proxy for services' and infrastructures' concentration (Vallebona et al. 2016), since this relationship is functionally related with both population concentration and land availability to building (e.g. Byrnes and Dollery 2002, Holzer et al. 2009, Larsen and Hertwich 2010).

The empirical results presented in this paper suggest that municipal size has progressively adjusted to population density, creating a more balanced spatial asset in the most recent decades (Rees 1992). Urban concentration typical of the 1970s in the study area was likely the condition that contributed the most to spatial variability and heterogeneity in the relationship between municipal size and population density (e.g. Salvati et al. 2013), possibly influencing the estimation of an optimal size for administrative local units, based on ex-ante criteria (Salvati et al. 2015). Transformations in municipal boundaries with the creation (or suppression) of new administrative units effectively reflect a progressive change toward a more balanced population distribution over space (Salvati and Zitti 2005). Spatially-balanced socioeconomic conditions seem to be a reasonable pre-requisite to an effective identification of optimal municipal size according to place-specific criteria (Salvati and Carlucci 2016). Municipal size decreased moderately over time with a slight increase in spatial heterogeneity; conversely, the average population density per municipality increased more rapidly with an evident reduction in spatial heterogeneity. The linearity and significance of the relationship between municipal size and population density both increased over time, reaching the highest values in 2011 (under the same spatial structure consolidated with the 'Kapodistrias' municipal asset) and reinforcing in the following years, under the renewed 'Kallikratis' spatial asset of local government units.

Taken together, these conditions represent a base for the informed analysis of the spatial structure of local administrative units and a pre-requisite for the identification of optimal municipal size (Dhimitri 2018). In line with earlier studies (Salvati et al. 2016, Bharath et al. 2017, Prasanth Warrier and Praseeja 2017), this work demonstrates how a quantitative analysis of the relationship between population density and municipal area, based on descriptive statistics, multiple correlation coefficients and regression models, provides basic knowledge for the identification of optimal municipal size, and it allows assessing the political and planning targets that involve a more balanced spatial distribution of population and land among local government units (Rose 2002, Zambon et al. 2017). Based on these empirical findings, the optimal municipal size should be regarded as a non-linear and evolving notion based on the intimate dynamics of the regional system under investigation. The use of dynamic criteria to determine the optimal municipal size over time and space is relevant in rapidlyexpanding metropolitan regions and, more generally, in economically-dynamic contexts with high residential mobility and re-location of activities into wider areas.

The policy implementations of the exploratory analysis developed in this work are grounded in the mutual interaction between population distribution, urban concentration and municipal size, with a specific focus on expanding metropolitan regions. The analysis proposed here was 
based on homogeneous indicators derived from official statistics over a long-time interval and on simplified statistical techniques, whose results provide a knowledge base for improved policies of local development and the sustainable planning of metropolitan districts in the light of the 'optimal municipal size' theory. The empirical evidence of this study indicates that a stronger integration between demographic, economic and political indicators is required to achieve a more comprehensive picture of local administrative structures based on an enhanced knowledge of the socioeconomic context differing among local communities. Further investigation is required to shed light on the intimate relationship between the changing spatial asset of local governance and the underlying socioeconomic transformations in progressively more complex and fragmented metropolitan systems.

\section{Conclusions}

Both changes in municipal boundaries and the creation (or suppression) of new administrative units reflect a progressive alteration toward a more balanced population distribution over space. Municipal size is a key variable delineating the amount and spatial concentration of services and infrastructures, being functionally related with population density, agglomeration factors, land availability to building and a characteristic profile of local communities in expanding metropolitan regions. The long-term relationship (1928-2012) between urban expansion, population dynamics and municipal area in a growing metropolitan region (Athens, Greece) was explored through a simplified statistical analysis of the relationship between population density and municipal area, providing basic knowledge to policy and planning adjustments toward a more balanced spatial distribution of population and land among the local government units. Descriptive statistics, mapping, correlation analysis and linear regressions were used to assess the evolution of such relationships over a sufficiently long time period and they proved to be a comprehensive analytical framework for the investigation of spatiallyexplicit issues associated with municipal size, population density and urban expansion. The average municipal area in Athens decreased moderately over time with a slight increase in spatial heterogeneity; conversely, the average population density per municipality increased more rapidly with a marked reduction in spatial heterogeneity. The results specify that municipal size has increasingly adjusted to population density across metropolitan regions, determining a more balanced spatial distribution of the resident population. Such conditions provide an improved knowledge base for a spatially-explicit analysis of local administrative units and they justify an enriched, evidence-based discussion on the optimal size of municipalities and administrative urban districts. Further studies should develop a comparative analysis of municipal size under the changing socioeconomic conditions in different metropolitan regions of advanced countries, with the aim to corroborate the hypothesis formulated at the base of this work and to generalize the empirical findings of our study to vastly different background contexts.

\section{References}

ALLAN P. (2003), Why Smaller Councils Make Sense, Australian Journal of Public Administration 62 (3), 74-81.

ANDREWS R., BOYNE G. A. (2009), Size, structure and administrative overheads: An empirical analysis of English local authorities, Urban Studies 46 (4), 739-759.

BHARATH H. A., CHANDAN M. C., VINAY S., RAMACHANDRA T. V. (2017), Intra and Inter Spatio-Temporal Patterns of Urbanisation in Indian Megacities, International Journal of Imaging and Robotics 17 (2), 68-86.

BEL G., WARNER M. E. (2015), Inter-municipal cooperation and costs: Expectations and evidence, Public Administration 93 (1), 52-67.

BYRNES J., DOLLERY B. (2002), Do Economies of Scale Exist in Australian Local Government? A Review of the Research Evidence, Urban Policy and Research 20 (4), 391- 
Population Dynamics, Agglomeration Economies and Municipal Size: a Long-Term Analysis

414.

CAPELLO R., CAMAGNI R. (2000), Beyond Optimal City Size: An Evaluation of Alternative Urban Growth Patterns, Urban Studies 37 (9), 1479-1496.

CAREY M., SRINIVASAN A., STRAUSS R. P. (1996), Optimal Consolidation of Municipalities: An Analysis of Alternative Designs, Socio-Economic Planning Sciences 30 (2), 103-119.

CARLUCCI M., GRIGORIADIS E., RONTOS K., SALVATI L. (2017), Revisiting a Hegemonic Concept: Long-term 'Mediterranean Urbanization' in between city re-polarization and metropolitan decline, Applied Spatial Analysis and Policy 10 (3), 347-362.

CARRUTHERS J. I., ULFARSSON G. F. (2002), Fragmentation and Sprawl: Evidence from Interregional Analysis, Growth and Change 33 (3), 312-340.

CECCHINI M., ZAMBON I., PONTRANDOLFI A., TURCO R., COLANTONI A., MAVRAKIS A., SALVATI L. (2018), Urban sprawl and the 'olive' landscape: sustainable land management for 'crisis' cities, GeoJournal 84 (1), 237-255.

COLANTONI A., GRIGORIADIS E., SATERIANO A., VENANZONI G., SALVATI L. (2016a), Cities as selective land predators? A lesson on urban growth, deregulated planning and sprawl containment, Science of the Total Environment 545-546, 329-339.

COLANTONI A., GRIGORIADIS E., SATERIANO A., ZAMBON I., SALVATI L. (2016b), If the Sky Falls We Shall Catch Larks: Rethinking Land Quality and Desertification Risk into a Regional Science Framework, International Journal of Ecological Economics and Statistics 37 (3), 64-75.

COUCH C., PETSCHEL-HELD G., LEONTIDOU L. (eds.) (2007), Urban Sprawl in Europe: Landscapes, Land-use Change and Policy, Blackwell Publishing, London.

CUADRADO-CIURANETA S., DURÀ-GUIMERÀ A., SALVATI L. (2017), Not only tourism: unravelling suburbanization, second-home expansion and "rural" sprawl in Catalonia, Spain, Urban Geography 38 (1), 66-89.

DHIMITRI E. (2018), Analysis Related to Optimal Size of Municipality and Efficiency - A Literature Review, European Journal of Interdisciplinary Studies 4 (1), 131-138.

DOLLERY B., BYRNES J., CRASE L. (2007), Is Bigger Better? Local Government Amalgamation and the South Australian Rising to the Challenge Inquiry, Economic Analysis and Policy 37 (1), 1-14.

DOLLERY B., CRASE L. (2004), Is bigger local government better? An evaluation of the case for Australian municipal amalgamation programs, Urban Policy and Research 22 (3), 265-275.

DOLLERY B., JOHNSON A. (2005), Enhancing efficiency in Australian local government: An evaluation of alternative models of municipal governance, Urban Policy and Research 23 (1), 73-85

DUVERNOY I., ZAMBON I., SATERIANO A., SALVATI L. (2018), Pictures from the Other Side of the Fringe: Urban Growth and Peri-urban Agriculture in a Post-industrial City (Toulouse, France), Journal of Rural Studies 57, 25-35.

FEATHERSTONE K. (2015), External conditionality and the debt crisis: the 'Troika' and public administration reform in Greece, Journal of European Public Policy 22 (3), 295-314.

HLEPAS N.-K. (2010), Incomplete Greek Territorial Consolidation: From the First

(1998) to the Second (2008-09) Wave of Reforms, Local Government Studies 36 (2), 223-249.

HLEPAS N. K., GETIMIS P. (2011), Impacts of local government reforms in Greece: An interim assessment, Local Government Studies 37 (5), 517-532.

HOLZER M., FRY J., CHARBONNEAU E., VAN RYZIN G., WANG T., BURNASH E. (2009), Literature review and analysis related to optimal municipal size and efficiency, School of Public Affairs and Administration, Rutgers-Newark.

KASANKO M., BARREDO J. I., LAVALLE C., MCCORMICK N., DEMICHELI L., SAGRIS V., BREZGER A. (2006), Are European Cities Becoming Dispersed? A Comparative Analysis of Fifteen European Urban Areas, Landscape and Urban Planning 77 (1-2), 111-130.

KEIL R., BOUDREAU J.-A. (2005), Is there regionalism after municipal amalgamation in Toronto?, City 9 (1), 9-22. 
LADI S. (2014), Austerity politics and administrative reform: The Eurozone crisis and its impact upon Greek public administration, Comparative European Politics 12 (2), 184-208.

LARSEN C. A. (2002), Municipal size and democracy: a critical analysis of the argument of proximity based on the case of Denmark, Scandinavian Political Studies 25 (4), 317-332.

LARSEN H. N., HERTWICH E. G. (2010), Identifying important characteristics of municipal carbon footprints, Ecological Economics 70 (1), 60-66.

LASSEN D. D., SERRITZLEW S. (2011), Jurisdiction size and local democracy: Evidence on internal political efficacy from large-scale municipal reform, American Political Science Review 105 (2), 238-258.

LONGHI C., MUSOLESI A. (2007), European cities in the process of economic integration: towards structural convergence, Annals of Regional Science 41 (2), 333-351.

PILI S., GRIGORIADIS E., CARLUCCI M., CLEMENTE M., SALVATI L. (2017), Towards sustainable growth? A multi-criteria assessment of (changing) urban forms, Ecological Indicators 76, 71-80.

PRASANTH WARRIER C. B., PRASEEJA C. B. (2017), A Markov Chain Model for the Demographic Study: A Case Study on Urbanization, International Journal of Mathematics and Computation 28 (4), 21-30.

REES W. E. (1992), Ecological footprints and appropriated carrying capacity: what urban economics leaves out, Environment and Urbanization 4 (2), 121-130.

RONTOS K., GRIGORIADIS E., SATERIANO A., SYRMALI M., VAVOURAS I., SALVATI L. (2016), Lost in Protest, Found in Segregation: Divided Cities in the Light of the 2015 "OXI" Referendum in Greece, City, Culture and Society 7 (3), 139-148.

ROSE L. E. (2002), Municipal size and local nonelectoral participation: findings from Denmark, the Netherlands, and Norway, Environment and Planning C: Politics and Space 20 (6), 829-851.

SALVATI L., ZITTI M. (2005), Land degradation in the Mediterranean Basin: Linking biophysical and economic factors into an ecological perspective, Biota 6 (1-2), 67-77.

SALVATI L., CARLUCCI M. (2016), Patterns of sprawl: The socioeconomic and territorial profile of dispersed urban areas in Italy, Regional Studies 50 (8), 1346-1359.

SALVATI L., GARGIULO MORELLI V. (2014), Unveiling Urban Sprawl in the Mediterranean Region: Towards a Latent Urban Transformation?, International Journal of Urban and Regional Research 38 (6), 1935-1953.

SALVATI L., SERRA P. (2016), Estimating rapidity of change in complex urban systems: a multidimensional, local-scale approach, Geographical Analysis 48 (2), 132-156.

SALVATI L., GARGIULO MORELLI V., RONTOS K., SABBI A. (2013), Latent Exurban Development: City Expansion Along the Rural-To-Urban Gradient in Growing and Declining Regions of Southern Europe, Urban Geography 34 (3), 376-394.

SALVATI L., MAVRAKIS A., SERRA P., CARLUCCI M. (2015), Lost in translation, found in entropy: An exploratory data analysis of latent growth factors in a Mediterranean city (1960-2010), Applied Geography 60, 107-119.

SALVATI L., ZITTI M., PERINI L. (2016), Fifty years on: long-term patterns of land sensitivity to desertification in Italy, Land Degradation \& Development 27 (2), 97-107.

SALVATI L., TOMBOLINI I., GEMMITI R., CARLUCCI M., BAJOCCO S., PERINI L., FERRARA A., COLANTONI A. (2017), Complexity in action: Untangling latent relationships between land quality, economic structures and socio-spatial patterns in Italy, PLOS ONE 12 (6), e0177853.

SCHNEIDER A., WOODCOCK C. E. (2008), Compact, dispersed, fragmented, extensive? A comparison of urban growth in twenty-five global cities using remotely sensed data, pattern metrics and census information, Urban Studies 45 (3), 659-692.

SERRA P., VERA A., TULLA A. F., SALVATI L. (2014), Beyond urban-rural dichotomy: Exploring socioeconomic and land-use processes of change in Spain (1991-2011), Applied Geography 55, 71-81.

SINGELL L. D. (1974), Optimum City Size: Some Thoughts on Theory and Policy, Land 
Population Dynamics, Agglomeration Economies and Municipal Size: a Long-Term Analysis

Economics 50 (3), 207-212.

SØRENSEN R. J. (2006), Local Government Consolidations: The Impact of Political Transaction Costs, Public Choice 127 (1-2), 75-95.

STEINER R. (2003), The causes, spread and effects of intermunicipal cooperation and municipal mergers in Switzerland, Public Management Review 5 (4), 551-571.

TAVARES A. F., RODRIGUES M. (2015), The economic and political impacts of topdown territorial reforms: the case of sub-city governments, Local Government Studies 41 (6), 956-976.

UN-HABITAT (2009), Planning sustainable cities: global report on human settlements 2009, Earthscan, London.

VALLEBONA C., MANTINO A., BONARI E. (2016), Exploring the potential of perennial crops in reducing soil erosion: A GIS-based scenario analysis in southern Tuscany, Italy, Applied Geography 66, 119-131.

WOLFF M., HAASE D., HAASE A. (2018), Compact or spread? A quantitative spatial model of urban areas in Europe since 1990, PLOS ONE 13 (2), e0192326.

ZAMBON I., SERRA P., BENCARDINO M., CARLUCCI M., SALVATI L. (2017), Prefiguring a future city: urban growth, spatial planning and the economic local context in Catalonia, European Planning Studies 25 (10), 1797-1817.

ZAMBON I., FERRARA A., SALVIA R., MOSCONI E. M., FICI L., TURCO R., SALVATI L. (2018), Rural Districts between Urbanization and Land Abandonment: Undermining LongTerm Changes in Mediterranean Landscapes, Sustainability 10 (4), 1159.

ZITTI M., FERRARA C., PERINI L., CARLUCCI M., SALVATI L. (2015), Long-term urban growth and land use efficiency in Southern Europe: Implications for sustainable land management, Sustainability 7 (3), 3359-3385.

Initial submission: 08.05.2018

Revised submission: 24.09 .2018

Final acceptance: 22.04.2019

Correspondence: Department of Social and Economic Sciences, University of Rome 'La Sapienza', Piazzale A. Moro 5, I-00185, Rome, Italy.

Email: luca.salvati@uniroma1.it 



\title{
"LITTLE VIENNA" OR "EUROPEAN AVANT-GARDE CITY"? BRANDING NARRATIVES IN A ROMANIAN CITY
}

\author{
Lucian VESALON, Remus CRETAN \\ West University of Timişoara, Romania
}

\begin{abstract}
By connecting the literature on urban development processes in post-socialist cities with debates from the area of place branding, this paper critically examines recent narratives of city branding in Timisoara, Romania. The aim is to investigate one specific case in the reproduction and adaptation of global urban development policies and to examine its relevance for the context of post-socialist urban politics. Our findings indicate a specific circularity between city branding and urban development, which is used to align the city to the regional inter-urban economic competition and to promote it as a space of rapid development. The outcome is a mélange of different narratives, based on disparate histories and representations of the city, which are assembled in ad-hoc and often contradictory branding discourses.
\end{abstract}

Key Words: city branding, urban development, post-socialism, Timișoara, Romania.

\section{Introduction}

This paper examines recent developments in the politics of post-socialist cities. Our main contribution consists in connecting the critical literature on urban development processes, especially regarding post-socialist cities (Kostinskiy 2001, Stanilov 2007, Sykora 2009), with several specific debates from the area of city branding (Morgan and Pritchard 1998, Lucarelli and Berg 2011, Kavaratzis and Hatch 2013, Vanolo 2017). Specifically, we look at the production of city branding discourses in Timișoara, Romania, during the period 2013-2017. This paper holds a critical position on the development policies produced by city managers and it highlights the contradictions in the implicit development vision rolled out by urban planning authorities in Timisoara. The second line of critique proposed in our paper refers to the ad hoc construction of a city brand for Timișoara by its authorities. We mainly highlight the use of a highly conventional approach to urban development which is delivered as a competitive advantage of Timișoara in a regional, and even global competition between cities. We examine the efforts of the city authorities to assemble the disparate pieces of urban narratives and to use the idea of rapid and extensive urban development as a central signifier in the city branding discourse.

We start from the construction and reinforcement of specific urban identities through city branding and we explore the ways in which these identities are connected to ideas on urban development. Examining these connections, we note a certain circularity between city branding and urban development discourses in a particular post-socialist context. The analysis is focused less on the relation between branding and urban policies, but rather on urban development discourses which perform the function of city branding targeted mainly to its citizens. In focusing on the case of a medium-size city located in East-Central Europe, we attempt to contribute to the debates on city branding and urban marketization, which mostly focus on large cities in Western Europe and North America (Smyth 2005), and, more recently, in the Global South (Lucarelli and Berg 2011). 
City branding, post-socialist development and urban identities

In order to understand the relations between city branding and urban development in Timișoara, we need to briefly examine the theoretical assumptions and sources used in this paper. One important trend in urban studies is to examine the so-called "cities in transition" (Blanke and Smith 1999). This usually refers to the urban change induced by the processes of globalization (Schneider-Sliwa 2006). Sometimes, it denotes the ecological transformation of cities. In our case, transition covers two inter-related processes: the postcommunist transition per se and the impact of the broader global and European context on the local urban development. The first dimension refers to the complex urban changes resulted from the post-communist political and economic transitions (Kostinskiy 2001, Stanilov 2007). This was especially and symbolically important in the case of Timisoara, given that it was the place where the 1989 Romanian Revolution had started. The second dimension is the impact of global neoliberal trends on post-socialist urban changes. The critical comparative study of post-communist urban development focused on the implications of neoliberalism for the cities of Central and Eastern Europe (Smith 2007, Stanilov 2007, Sykora 2009). The multiplication of actors, the proliferation of urban development discourses calls for a more careful consideration of the type of neoliberal urban development currently unfolding in post-socialist cities. In this context, the contribution of city managers to boosting the global competition between cities plays a key role in the consolidation of a truly global managerial approach to urban development (Leitner et al. 2007, Çaglar and Glick Schiller 2018).

We propose using the term "normalized development" in post-socialist cities in connection to the path followed by the city of Timișoara along the above mentioned processes. The normalization of development is based on ideas and practices pertaining to economic development, spatial politics and social engineering in urban contexts - all leading to more productive, efficient, and predictable spaces for economic growth, and to specific transformations of social practices connected to urban development. This idea resonates with the critical analyses of neoliberal urban development in Western, post-socialist and developing countries (Brenner and Theodore 2002, Stenning et al. 2010). It also echoes the idea of conventional development, the critiques of the hegemony of neoliberal urban politics and the adaptation to various local contexts (Chelcea and Druţă 2016).

On one hand, urban development trends in Timișoara follow the general lines observed in the majority of post-socialist cities from Central and Eastern Europe. The multifaceted transformations of urban space as the result of global neoliberalization, together with the alternative urban developments, have been discussed in critical urban studies (Leitner et al. 2007). Several trends have been considered in post-socialist urban studies, ranging from the development of new retail urban landscapes, to de- and re-industrialization processes and brownfield transformations (Smith and Rochovská 2006, Leitner et al. 2007, Voiculescu and Jucu 2016, Tursie 2017). For instance, the growth of 'out-of town retail landscape' of postsocialist cities is one of the most visible urban development patterns in post-communism, being widely mentioned in the literature (Leitner et al. 2007, Sykora 2009). Another well-covered direction is the examination of gentrification and socio-economic segregation in post-socialism (Gentile et al. 2012), the case of Romanian cities being relatively well documented (Voiculescu et al. 2009, Marcińczak et al. 2014).

On the other hand, urban development trends in Timișoara follow the specific experiences (already problematic) of the Western urban context. These include the attempt to identify the so -called leading industrial sectors and the prioritization of economic growth over social cohesion and environmental protection. The support for the spatial expansion of the city, known as urban sprawl, is also important. Similar urban growth patterns are found in the majority of large postsocialist urban centres (Sykora 2009). For instance, lanoș et al. (2016) discuss the mechanisms of the uncontrolled urban space growth, specifically the dynamics of built-up 
space in Bucharest, showing how post-socialist transformations create specific divergent patterns of urban growth. Yet, as we discuss later in this paper, the most conspicuous trend in urban development remains that of integration in the urban regional and global competition as urban growth poles and competitive cities. This closely relates to our topic, since competition between cities in the current global context is well reflected by city branding (Vanolo 2017: 53).

The field of city branding studies is expanding at an impressive rate, making available numerous theories and perspectives, through dedicated journals and thousands of carefully documented case studies. The specific contribution of this paper consists in connecting branding and urban development discourses in the post-socialist context. Since the terminology is fluid, similar terms - city marketing, place branding, city branding and others (Lucarelli and Berg 2011: 19) - are circulating in parallel as approximate synonyms. However, we have opted for using the term city branding. In doing so, we seek to make more visible the participation of political actors in the construction of local urban branding discourses. The connection between political power and place branding is often examined in the literature, given that the latter is "an expression of the interest of a particular group, or groups, of imagineers and hence it is always a political act that is intended to produce particular effects" (Johansson 2012: 3613). Such evaluations contribute to the critical orientation of much of the existing place branding studies.

Several directions have been established in the area of place branding studies, the construction of place brands and the uses of branding and the critical analysis of branding (Lucarelli and Berg 2011, Kavaratzis and Hatch 2013). In relation to our research area, case studies on Romanian cities are surprisingly scarce (Groza et al. 2010). We position our approach to city branding in the area of critical perspectives on the construction of place branding. The critical dimension usually consists of examining the "positive/negative factor for the economic, social, and cultural environment" (Lucarelli and Berg 2011: 18). Our critical focus is placed rather on the broader political dimension of branding construction. The political dimension of branding is not limited to the participation of local authorities in the production of city branding. It is also part of a more encompassing "politics of place" (Lucarelli 2018), which includes a variety of actors, interests, and ideologies. Together, they account for that fact that "branding is best understood as dialogue, debate, and contestation" (Kavaratzis and Hatch 2013: 82).

This critical perspective on branding brings to the fore the contribution of political power in the process of branding construction (Çaglar and Glick Schiller 2018). In close relation to the politics of branding, our interest refers to the construction and the reproduction of specific branding discourses in a post-socialist context. However, city branding is not only about constructing representations of cities, but it is also a process of materialization or material transformations of cities (Lucarelli 2018). City branding is a key component of what we call it "normalized development". This interpretation is well illustrated by the idea that "place branding is a narrative programme that aims at redescribing place by means of sanitising, obscuring or alternatively emphasizing chosen aspects of reality" (Johansson 2012: 3613).

An important topic in city branding analysis is the correlation between specific branding discourses and target groups. Well-known groups targeted by city branding discourses are foreign tourists and potential investors (Lucarelli and Berg 2011). In our case, however, we have noticed another trend, that of targeting the local population through discourses aimed at constructing specific urban identities. This confirms the function of branding in "constructing and conveying a chosen imaginary of a place and formulating a concept that resonates with a chosen target group..." (Vanolo 2017: 38-39). The targeting of the local population through branding discourses with the aim of reshaping the image of the city and the identities of its citizens is a mainstream manifestation of the politics of branding. Moreover, as we discuss further, city branding is also increasingly involved in planning strategies (Lucarelli 2018), thus becoming a key component in shaping urban development discourses. 


\section{Methodology}

We have followed a process-based approach to place identity in which branding is understood as "a facilitator of the identity process" (Kavaratzis and Hatch 2013: 79). The issue of representation and image construction is particularly important for our case, since branding discourses re-activate and re-construct previous representations and histories of cities, but they also construct entirely new images (Johansson 2012). In close connection to branding discourses, we find the more general question of the construction of urban identities for residents. As Vanolo (2017: 54) explains, city branding has an important function for its inhabitants: "infusing a sense of trust" and "creating a strong local identity". The role of cities in the construction of social identities is widely acknowledged and increasingly important with the rise of global mega-cities (Leitner et al. 2007). Building on this common knowledge, we seek to determine how urban development processes and city branding strategies produce and reinforce specific urban identities.

The methods used in this paper mainly include the critical analysis of local urban policy documents and of the monthly publication of Timișoara Municipality - Timișoara Municipality Monitor (Timișoara Municipality 2017). Examining urban development in Timișoara, we contend that the Monitor performs multiple functions, the city branding targeted principally to the citizens of Timișoara being among the most interesting communication vector. The Monitor is distributed for free to basically all postal addresses, making it the widest reaching print in the city. Its archives are also available online. We focus on the branding discourses and visions of development deployed in the Monitor. We also discuss the visions of urban development articulated in two major official documents, on which urban development policies are based, specifically Timișoara Master Plan (Timișoara Municipality 2012) and the Integrated Development Plan - Timișoara Growth Pole (Timișoara Municipality 2010). These two documents are the main empirical sources for the content analysis of the urban development plans. The online archives of Timișoara Municipality Monitor (2017) are used for identifying the specific representations of urban development which are then articulated to city branding discourses.

The timeframe of the analysis is between January 2013 and December 2017. Although the Monitor includes multiple issues and sections, we focus on the editorials of the Mayor, which best reveal the marketization of specific urban development visions. This selection of empirical sources thus limits the conclusions of the research, but it also provides a focus on the contribution of a dominant political actor to the production of particular urban development and city branding discourses. In close relation to urban development discourses, we find specific attempts to generate a city branding strategy and to reinforce particular urban identities for the citizens. In examining the case of Timișoara, we follow the trend of a single case study approach, which is the most frequently adopted as methodological option in numerous city branding studies (Paddison 1993, Lucarelli and Berg 2011). At the same time, we consider that our case study is relevant in a comparative perspective for a larger group of post-socialist cities, where the process of city branding construction is unfolding in a perceived environment of increasing regional and global competition between cities.

\section{Results and Discussion}

\section{Seeking an urban development narrative for Timișoara}

Like other post-socialist cities, Timișoara is currently struggling to identify itself in the national and in the broader regional, economic and political urban environment. A fundamental process of neoliberalisation, beginning shortly after the fall of the socialist regime, has deeply transformed the urban politics of the city. The Europeanization and globalization of urban 
"Little Vienna " or " European Avant-Garde City ? "Branding Narratives in a Romanian City

development was generally more accelerated than in other cities of the region. The discovery of global and regional competition brought with it the perception of a much-needed place brand for the city. Older urban narratives (from the pre-communist period) intersected with newer ideas on global competition between cities in the efforts to build new urban development discourses and urban identities.

Timișoara prides itself with a special position in the post-socialist arena. In 1989, Timișoara was widely acclaimed as the city of the revolution against the communist regime in Romania. It has a population of more than 300000 inhabitants and a diverse ethnic and religious structure (Crețan et al. 2008).

City integration in the regional economy and the cross-border cooperation have been significant factors in post-socialist urban development in Central and Eastern Europe (Ilieș and Grama 2010, Ilies et al. 2012). The position of Timișoara in the very heart of the Danube-CrișMureș-Tisa (DKMT) Euroregion has contributed to its relatively high integration in the regional economy. In the last two decades, Timișoara had one of the fastest growing economies in the region, with comparatively high foreign direct investments, low unemployment rates and high economic outputs compared to the national average (Eurostat 2018a). However, this picture is certainly far from complete and the apparent prosperity and progress of Timișoara conceal various contradictions and inconsistencies, some of which will be discussed later in this paper.

In Timișoara, the dismantling of the former communist urban planning translated into a following less coordinated and integrated urban management. The lack of a clearly articulated development strategy in the 1990 and 2000s is mentioned in many official documents of the city council (Timișoara Municipality 2012). Following the integration of Central and Eastern Europe in the regional and global economy, post-socialist cities sought to elaborate new urban development strategies, mainly to boost growth and to use the new perceived opportunities resulting from this integration (Sellar 2013). After the EU accession in 2007, European integration was an incentive for new urban development strategies. In Timișoara, the most recent efforts of constructing a development vision for the city consists of a plan for a 'regional growth pole', which includes different dimensions, strategies and policies. This situates the city in a competition with other urban centres in the region to attract global investments and it increases the pressure to create 'business-friendly' environments. This dimension is particularly relevant for understanding the pressure to produce a city branding strategy for Timișoara.

The current urban development strategy for Timișoara (Timișoara Municipality 2018) is based on two main official documents. The first document is the newly elaborated Timișoara Master Plan (Timișoara Municipality 2012) by which urban spatial management is regulated. The first new Timisoara Master Plan was released in 1999 and then replaced by the subsequent plans in 2002, 2007 and 2012. The second document is the IDP (Integrated Development Plan, Timișoara Municipality 2010), subsequently updated by the ISUD (Integrated Strategy of Urban Development, Timișoara Municipality 2018), which offer an integrated strategy for the development policies in the area of Timișoara. We note that even in these rather technical urban development policy documents, there are threads and pieces of a city branding discourse for Timișoara, although there are no dedicated frames for this. Timișoara Master Plan and IDP/ISỦD include at least three main signifiers which point in this direction: 'competition', 'innovation' and 'multiculturalism'. These three components are used to define the advantages in the marketisation of Timișoara as a key competitor in the region.

Different features of the city are interpreted as competitive advantages - its geographical position, especially its proximity to the European transport corridors, is frequently mentioned and presented as a unique opportunity for locating export-oriented businesses in the area. Timișoara is included in the Pan-European Corridor IV, via the A1 Highway in Romania and 
Highway in Hungary. The relatively cheap and skilled workforce provides another economic advantage, which led to the focus on foreign investments and integration in the European economy. In 2015, the GDP of the metropolitan region of Timișoara was of 7566 million Euro, while in Cluj-Napoca it was of 7020 million Euro and in Bucharest it was of 44511 million Euro (Eurostat 2018a). However, productivity measured in GDP/person in Timișoara is more than $30 \%$ higher than the national average, while in Cluj-Napoca it is $149.9 \%$ higher and in Bucharest is $203.2 \%$ higher than the national average (Eurostat 2018b: 198). Regionally, the city entered a competition for attracting international investments and it has started marketing itself as a "growth pole" (Fig. 1). The priority of economic growth in urban development is thus closely connected to the imperative of attracting foreign investments in the city. Prominent examples are production sites and offices opened in the city by multinational companies such as Continental, Nokia, Coca-Cola, Procter \& Gamble and other global players in the industrial, retail, and IT sectors. Prioritizing economic growth is a common feature of the reproduction of global neoliberal urban policies at local levels (Leitner et al. 2007) and a marker of a 'normalized development'.

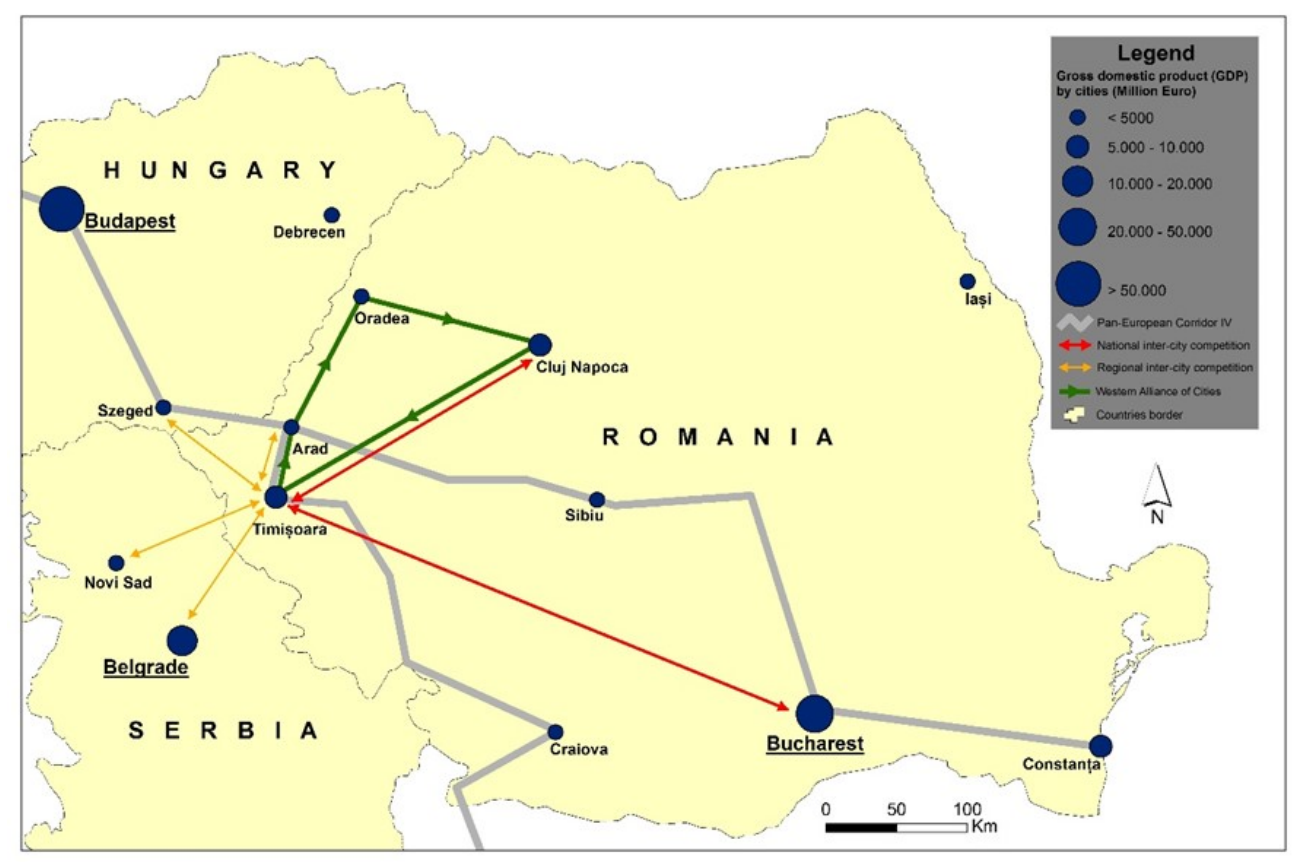

Fig. 1 - Timișoara - competition and cooperation in the regional context Source: Eurostat (2018b). Map implemented in GIS by Fabian Timofte, based on content provided by the authors

The rush for foreign direct-investment (FDI) was always central to the management of postsocialist cities and in national economic policies (Crețan et al. 2005, Sellar 2013, Choromides 2018). The prospects of accelerated economic growth is connected not just to foreign investments and the location of cities, but also to the dimension of the national economy (Yao et al. 2018). The FDI rush in the entire post-communist space is well reflected in the development discourses of the city authorities. For instance, Timișoara Master Plan mentions how "Financial Times journalists have praised Timișoara for its rapid development and the attraction of 8000 foreign companies" (Timișoara Municipality 2011: 80). Similarly, the IDP 
" Little Vienna " or " European Avant-Garde City ? "Branding Narratives in a Romanian City

constantly reproduces the image of Timișoara as a pioneer in economic development internationally and regionally integrated '(Timișoara Municipality 2010: 136, Timișoara Municipality 2018: 2-6). The focus of urban development policies on attracting FDI is in tune with the mainstream policies adopted by the majority of post-socialist cities and also with city branding strategies (Metaxas 2010). As we will see in the discussion of the Monitor, the representation of Timișoara as a business-friendly environment is a key dimension in the city branding discourse and one of the reasons for considering its urban policies as a form of 'normalized development'.

'Innovation' is the second core signifier in the urban management discourse. The city's research and innovation sector is used as an urban marketing 'selling factor' and it is defined as an engine of economic development (Timișoara Municipality 2010: 135, 147). In the growth pole strategy, there is a focus on high-tech, communications and "creative services" as development opportunities. This reflects the connection of local politics with the broader concept of "creative cities" and its correlative notion of "creative class", topics heavily discussed in urban studies in connection to Western cases, but being almost absent from the literature on post-socialist cities (Borén and Young 2013).

The third signifier in the urban development policy documents is multiculturalism. The Growth Pole strategy is suggestively named 'Integrative and avant-garde multicultural space'. The urban management discourse is rich in references to the image of multiculturalism, for instance in referring to Timișoara as a "symbol of freedom and of tolerant multiculturalism" and as "one of the most cosmopolitan cities in Romania" (Timisoara Municipality 2010: 139, 239, Timișoara Municipality 2018: 2). Timișoara has a relatively rich ethnic diversity, with more than 15 ethnocultural groups (Romanians, Hungarians, Roma, Serbs, Germans, Italians, etc.). The city praises itself with a multicultural setting, reflected in diverse multi- and inter-cultural institutions. This ethno-cultural landscape is used to produce or reinforce the representation of a unique multicultural city. The use of multiculturalism as a key component in the unfolding of neoliberal urban development framework and initiatives was already noted for the case of Timisoara (Mădroane 2012). Particularly interesting is the use of the multiculturalism in connection to the urban development strategies and discourses. In various contexts - entrepreneurial, academic, cultural, scientific - the multicultural background is presented as a main comparative advantage for urban development. For instance, the existence of a German minority in the city is used to account for the presence of relatively large investments by German companies in the local economy. Important in our analysis is how the image of multiculturality is presented as a unique facilitator of economic development. The urban management discourse explicitly connects multiculturalism, social stability and economic growth, by stating: "ensuring an intercultural, cohesive and stable environment, favourable to progress is a sine-qua-non condition for development" (Timisoara Municipality 2010: 138-139). The correlation between multiculturalism and competitiveness is also explicitly formulated: "[Timișoara's] open, tolerant, multicultural character brings important advantages in the international competition" (Timișoara Municipality 2010: 134), being an "intercultural and economic bridge between the three neighbouring countries" (Timișoara Municipality 2018: 11).

Multiculturalism and innovation are thus closely connected to the idea of regional competitiveness. Both Timișoara Master Plan and IDP/ISUD advance the idea of a 'dynamic' city situated in a regional and global competition for economic growth. Such policies demonstrate the increasing adoption of "globally-circulating policies" in the Eastern European urban development context (Çaglar and Glick Schiller 2018). From this it follows the perceived need of an integrated urban branding strategy to promote the city as a unique competitor in the region: "Timișoara lacks urban marketing strategies to encourage new initiatives and to contribute to the coordination of public, academic and private, national and international sectors" (Timișoara Municipality 2011: 8). Following the imperative of economic competitiveness, city authorities therefore proposed a new city marketing strategy, as an effort 
to discover or define the "city's own style" (Timișoara Municipality 2011: 18) and eventually to "highlight the identity of the area" (Timișoara Municipality 2010: 146). As we see in the following section, the Monitor provides a complementary, albeit unsystematic and ad hoc urban branding discourse, by developing and contextualizing several representations of the city.

\section{Branding Timișoara: 'Little Vienna' or 'in-force development'?}

In this section, we shift the analysis towards the ways in which urban development discourses establish a circular relation with city branding narratives. We use the hypothesis that city branding in Timișoara is predominantly targeted to its own citizens, thus achieving specific functions, and less towards external actors: tourists, foreign companies, other cities etc. (Vanolo 2017). In the absence of a coherent and innovative urban development vision, city authorities struggle to produce a city branding discourse through which various disparate elements of urban development are put together. The resulting assembly is an important piece in a broader scenario of post-socialist urban politics.

As in the case of all post-socialist cities, a plethora of economic and social processes have shaped the urban geographies of Timișoara after the fall of communism. We have mentioned political change, transition to capitalism, gentrification, urban sprawl, and segregation as key dimensions of urban transformation. Urban development processes followed a similar pattern in Central and Eastern Europe (Stanilov 2007), generally determined by the guidelines provided by the neoliberal model (Pickles and Smith 1998, Smith and Rochovská 2006).

To understand the "normalization of development" in urban context, we examine the construction of city branding in the monthly Monitor edited by Timișoara Municipality (2017). The Monitor has multiple functions. At its most evident level, it informs the citizens and it describes the activities of city authorities. It routinely includes inventories of administrative accomplished tasks, various achievements of city authorities and discussion of everyday issues. Besides these functions, we bring to the fore another important role, that of constructing an urban development discourse, which articulate specific visions of urban development. These discourses then serve to legitimize public policies, to gain electoral capital for the Mayor and his party, to advertise for city hall initiatives, and to personalize the political power. As it was recently noted, place branding is closely linked to the capacity of political actors to control the political environment (Lucarelli 2018). And, it also signals how public input and the citizens' participation to the process of brand construction become more limited, despite the inclusion of formal consultation in the very definition of place branding (Kavaratzis and Hatch 2013: 72).

The Monitor is used to forge a representation of the city and to fix an urban identity mainly for its citizens. The result is an unsystematic and hybrid branding construct, based on many of the previous elements of political communication, oral histories, local cultural stereotypes, to which several newer components from the city administration and the Mayor's rhetoric are added, and which are put together in an ad hoc branding discourse. A key dimension is the personalization of political power and of the development and branding discourses in the Monitor. The first page of the city Monitor typically includes the Mayor's editorial, a key component which covers recurrent references and inventories of various development projects, usually delivered as city hall success stories. The Mayor of Timișoara, Nicolae Robu, is a leading member of PNL (the National Liberal Party) and he began his electoral mandate in 2012.

The Monitor has important political functions, serving as a political communication platform for the Mayor and for the City Council. We often find local authorities involved in political debates and tensions with other political actors, such as the central government and in struggles between political parties. The tensions with the central government intensified after 2014, 
when the coalition with the governing party, PSD (the Social Democratic Party), to which PNL took part, had disintegrated (The Monitor February 2014). After the break of the coalition, the Mayor of Timișoara became more polemical in his dealings with the central government than in the previous period. Significantly, the center-periphery tensions were reinforced in the Monitor and it was used to legitimize various policies and specific decisions made by the local authorities, and, especially, to boost the popularity of the Mayor. Given that regionalist attitudes are relatively strong in the region of Banat, regionalist stances and discourses are frequently constructed in opposition to the capital city - not only in political, but also in cultural terms (The Monitor September 2014: 1, October 2014: 1). The tensions between the Mayor and the central government even lead to anti-governmental protest incites: "together we shall succeed!" (The Monitor February - March 2015: 1). The Monitor is even used for the political mobilization of citizens specifically against the central authorities. As we discuss further, such mobilizing messages play a key role in the construction of city branding for Timișoara.

The very titles of the editorials are often mottos and mobilization slogans aimed at the city's fast development and growth. Even one of the logos of the Monitor is suggestive in this sense, based on the word play included in 'Revolutionary', with 'evol' highlighted and TM pointing both to the idea of a trade mark and the abbreviation of Timișoara (Fig. 2). Timișoara is the revolutionary city because the 1989 Revolution has started here, and it is also 'evolutionary' because of its claimed leading position in urban development, at least in Central and Eastern Europe. And Timișoara is supposedly a trade mark because it provides unique features and great opportunities for urban development. In 2016, the logo was replaced by the tag "Timișoara 2021 European Capital of Culture". The importance of city logos for city identification is a much discussed feature of place brand formation (Kavaratzis and Hatch 2013), and the changes of Timișoara's logos confirm the unsystematic character of its branding strategies.

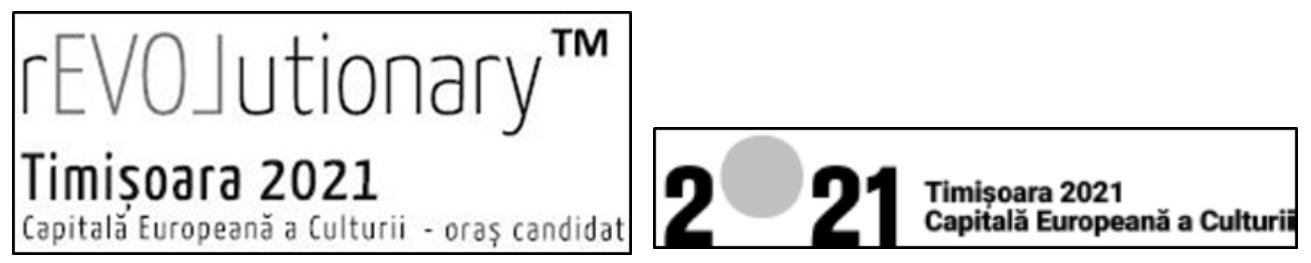

Fig. 2 - Logos of Timișoara

Source: Timișoara Municipality (2017)

As we have already mentioned, after the initial phase of urban decline following the collapse of communism in the region, post-socialist cities sought to regain control of urban development and boost city growth (Stanilov 2007). Our finding indicates the construction of a new urban development discourse in Timișoara, based mostly on the belief that the city has to develop in force, fast and through big projects. Moreover, development processes put the city in direct competition, at national and regional level, if not at global level, with other cities. A specific dimension in the urban development discourse is the persistence of a more general feature of the Romanian politics (Vesalon 2010), namely the deployment of a modernization vocabulary. In the context of Timișoara city branding, the language of modernization is effectively wrapping up the urban development. The idea of "in force modernization" is a recurrent communication vector (The Monitor August 2013, September 2015, January 2017). Typical expressions are, for instance: "Timișoara modernizes itself in a sustained pace" (The Monitor March 2014: 13), and: "Yes, Timișoara modernizes itself in force" (June 2014). The idea of rapid modernization is linked to the city authorities' voluntarist approach, which places the figure of the Mayor at the centre of urban development processes. 
The idea of urban development through 'big projects' or 'major projects', usually infrastructure projects, is a central dimension and a recurring reference in the Monitor (The Monitor January 2013, April 2013, November 2013). The city administration's 'portfolio of big projects' becomes a core reference in the discourse of the mayor (January 2014). Frequent mobilisation messages are often included in headings such as "...We will make many big things..." (The Monitor June 2016: 1). The Monitor often resemble a 'construction works journal', with a focus on the biggest infrastructure projects, for instance the enlargement of two main roads (Jiul and Popa Șapcă) which drive under railway lines in 2016-2017. Moreover, the year 2017 was, in fact, described as "a decisive year for preparing big projects" (The Monitor January 2017: 1). These projects draw a disproportionate attention in the public's eyes because of the Mayor's insistence on the topic, but also probably due to the rarity of big infrastructure projects at national level and of the high popular expectations on such projects. This illustrates the idea that investments in infrastructure in general are not only part of urban development per se, but they play a significant role in city branding. As Vanolo (2017: 11) explains, "...the improvements surely have to be communicated to an audience of potential external enterprises in order to maximise the effects of investments".

The prioritization of infrastructure works is a persistent dimension of conventional development approaches, both in urban and national contexts. Basically, the improvement and changes in infrastructure (of all types) can be seen as a precondition for the import of global urban policies (Peck and Tickell 2002, Peck and Theodore 2015) and to the participation to inter-urban competition. Indeed, a recurrent idea in the Monitor is that 'infrastructure modernisation' is instrumental to economic growth and to support Timisoara in the competition with other cities in the region. This, in turn, invests city authorities with the main task of facilitating growth. The language of 'modernization' therefore dominates the references to infrastructure works in the Monitor. Such evolutions are neither recent nor regionally specific. Similar trends were present in the early twentieth century in North American cities and in the twentieth century in Europe (Desfor et al. 2011). The priority of big projects and the focus on infrastructure improvements especially in the city centre confirm the fundamental idea that "brands and space mutually constitute and shape each other, how do brands shape the soft and hard infrastructure of urban spaces" (Lucarelli and Berg 2011: 22).

Similarly, the representation of 'rapid development' and accelerated growth is revealed in many editorials. The high speed of city development is typically included in the authorities' vision of governing the city. For example, reminders of "keeping the high pace of city development" (The Monitor editorial title April 2017: 1) are routinely presented in the editorials. The idea of development through 'big projects' is then correlated to the representation of Timișoara as a competitor in the regional and global economic arena. A particular evolution in the case of Timișoara is represented by its link to widespread cultural stereotypes about other regions in the country and mostly about the country's capital. A 'rivalry' with several Romanian cities is often reflected in the Mayor's editorials (The Monitor May 2014). This reproduces and enhances another belief, according to which Bucharest, the "centre", contributes to Timișoara's lagging behind in the pursuit of development. The Monitor even constructs an image of a solitary, heroic city for Timișoara, in the regional and global competition, without any support from the central authorities, left alone on its development path (The Monitor September 2017: 1). However, a recent evolution of events brought together four Romanian cities - Cluj-Napoca, Oradea, Arad and Timișoara - which engaged in a joint initiative, called " the Western Alliance". Its declared purpose is to accelerate and facilitate regional urban development and economic growth, mainly through improving and expanding the regional infrastructure and through attracting EU funds.

In connection to its European ambitions, Timișoara has applied to host the 2021 European Capital of Culture (ECOC) and it won the title in 2016. This victory was rapidly incorporated in the discourses of urban development in Timișoara. The candidacy and the subsequent winning 
"Little Vienna " or " European Avant-Garde City? "Branding Narratives in a Romanian City

of the ECOC title provided a new opportunity for the city authorities to develop their city branding discourses. Indeed, similar evolutions were noted for other post-socialist cities, mostly in connection to the changes in urban development policies in connection to their ECOC status (Lähdesmäki 2014). After winning the ECOC title, the marketization of the city as a rapidly developing urban centre gained momentum. The first Monitor of 2017 read that "Timișoara will shine in 2021" (The Monitor January 2017: 1). The preparations for ECOC provided a new sense of urban development mission for the city authorities and a civic mobilization for the citizens. The projects and works for the 2021 ECOC became a pillar of the urban development discourses. It is important to highlight a significant shift: if until 2016 the ECOC was used as a means to attain development goals, after winning the title, ECOC became itself the goal for which urban development is deployed. Even from the stage of ECOC candidacy, this was used to mobilize the citizens' support for multiple projects proposed by the city authorities. A parallel is drawn to the 1989 Revolution: "gaining the [ECOC] title is an objective which could make us find again that extraordinary solidarity from December 1989" (The Monitor April 2014: 1). Currently, ECOC is used as a strong mobilizing argument for rapid urban development in tandem with its inclusion as an element of city branding (Timişoara Municipality 2019), such evolutions being reported throughout Central and Eastern Europe in the past two decades (Lähdesmäki 2014).

The 'return to Europe' is one of the most enduring political myths in Central and Eastern Europe, frequently reproduced after the fall of communism. Eurocentric discourses are widely used for political and cultural purposes in the region, more often so after the fall of communism in 1989. Timișoara as a 'European city' and its 'European belongingness' represent fundamental pieces both for the construction of an urban identity and for the urban development discourses. Timișoara is traditionally referred to as 'Little Vienna' in various contexts. For instance, we find that the city administration has opened up "70 construction sites for Timișoara to become 'Little Vienna' again" (The Monitor October 2013, November 2013) or that "the Central Park will become a beautiful Viennese garden" (The Monitor January 2017: 7). Symptomatically, such references are usually produced in connection to infrastructure works. Such comparisons are not new and not specific to Timișoara only as the comparison of Eastern European cities with other Western and Central European capitals is very common - for instance, Bucharest is called 'little Paris' and Sankt Petersburg is also known as 'the Venice of the North'.

Multiculturalism is one of the key elements in the representations of the city within the local culture, in urban management and branding discourses. Soon after 1989, multiculturalism was offered as a possible thread for reconnecting Timișoara to Europe. In fact, as Mădroane (2012: 36) shows, multiculturalism is an ingredient in (re)constructing the city history after the fall of communism by "a strategy of recovering its (utopian) past". Indeed, multiculturalism is reinvented as a distinctive feature of the city, based on the perception that Timișoara is unique in respect to its ethno-cultural diversity and on deliberately obscuring the fact that numerous other cities in Romania have a rich ethnic, religious and cultural diversity. Well-known examples include Constanța, București, Cluj-Napoca, or Sibiu.

The political myth of the glorious past of Timisoara is also recurrent in the Monitor. It is based on multiple elements, ranging from historical and political events, cultural and architectural heritage, to technological premieres. The 1989 Revolution is a core signifier incorporated in the local branding discourses. The historical and political condition of the 'city of the Revolution' is easily connected to the neoliberal competition between cities. In fact, the very idea of place branding in the region was linked to ideological elements, i.e. explicitly neoliberal and implicitly anti-communist positions (Szondi 2007). References to the Revolution as a part of city's identity are numerous, typically stating that "Timișoara has won for the Romanian people the right to dignity and it has become the nation's consciousness" (The Monitor November 2014: 1). The idealization of the past leads to the previously discussed idea of rapid development, as 
one could note in the following phrase: "we are changing the city, developing it in force, and restoring its past glory" (The Monitor July 2015). The image of a glorious past is then deployed to mobilize the citizens' support for various urban development initiatives through slogans such as: "Let's give back to Timișoara its deserved charm and glamour" (The Monitor July 2013: 1, June 2014: 10). Such examples confirm a popular idea in branding studies, namely that "the rebranding of a place often leans on reinvoking a nostalgic past, pointing to cultural or historical circumstances which are seen to lend to the place a desired aura" (Johansson 2012: 3615).

The idea of "past glamour" (The Monitor December 2013) is used in connection to various achievements in the history of the city. In close connection to the image of a glamourous past stands the representation of Timișoara as the "the city of European premieres" (The Monitor April 2013: 12). Timișoara's 'firsts' include the first urban hydropower plant in Europe, the first electric tramway, the first city with street electric lightning, and other achievements less mentioned or known, such as the city where non-Euclidian geometry was discovered by János Bolyai. Other examples are Timișoara's 'traditional brands' (The Monitor May 2013), such as Timișoreana local beer factory, built in 1718, Guban shoes factory and Kandia chocolate factory.

Sometimes, different representations of the city are thrown on paper in an effort to demonstrating the strengths of the city. One good example is labelling the city as "the most powerful economic pole in Romania, after Bucharest", the "most dynamic city", "a strong cultural pole", a multicultural city living in "peace, harmony and synergy" (The Monitor January 2015: 1, 5). As a former Rector of the Polytechnic University, Nicolae Robu often speaks about Timișoara becoming "a university and research pole" (The Monitor April 2014: 3). Other references to the identity of the city recall the image of Timișoara as the "city of flowers" and as the "city of roses" (The Monitor July 2013). All these representations converge to boost the confidence of citizens and local authorities in the capacity of the city to become a strong urban centre in the region and thus to reconnect to its much celebrated past: "together we will make Timișoara glow again" (The Monitor July 2017: 1).

We conclude that the core dimension in the city branding discourse of Timisoara is the representation of a city in constant and strong regional, national and global competition. Symptomatically, the Monitor insists and it reiterates the information related to any inclusion of Timișoara in various economic and business rankings and prizes, which are presented as extraordinary achievements. The most invoked is the Forbes (Romania) prize for "the most dynamic city", awarded to Timișoara in 2014 and 2016. Forbes has also evaluated the business environment in 40 Romanian cities, and it awarded Timișoara for the position of best city for business (Forbes 2015). Another "vanity prize" was the title of priority destination city for investments offered by the European Business Assembly. The surprising influence of such rankings is visible in how the representation of "the most dynamic city" was widely circulated as a branding label in the Monitor (February 2014, March 2014, February 2016) and put in relation with other similar labels, such as the "engine of economic development", "healthy business environment", "locomotive of economic development" (The Monitor February 2016: 1-2). It is suggestive that business newspapers and various business organizations are used as authoritative and legitimizing sources for the urban management policies of the current city administration, leading to the representation of Timișoara as a "European avant-garde city" (The Monitor February 2016: 1).

We have seen that the Monitor performs various functions and we have highlighted its use for the purposes of particular and ad hoc city brands. The attempt to produce representations of the city and then combine them in a city branding product is largely based on the tricky assumption that almost "anything goes" if it is constantly repeated. Branding studies illustrate how the process of image construction for cities faces counter-discourses, scepticism, but also 
the sheer ability "to convince people that these messages are true" (Kavaratzis and Hatch 2013: 74). In the case of Timișoara, branding discourses encapsulate the ambitions of postcommunist cities to become economic growth poles and urban centres integrated within the regional and global capitalist networks, in parallel with consolidating a local urban identity for its citizens. At the same time, such branding discourses are vulnerable not only to the so-called 'reality checks', but also to the specific contradictions of urban development in the regional economic and political context.

\section{Conclusions}

The development of post-socialist cities followed a path of economic growth in a regional context. The general perception that the break with the socialist past would somehow naturally imply the idea of neoliberal competition between cities in the region also led to the mimetic efforts of translating urban policies from the global level, often in an unsystematic and contradictory manner. We have called this process 'the normalization of development' and we have documented how it connected with the production of ad hoc branding discourses in Timișoara. One core idea in this framework is the marketization of the city as space for free market economic initiatives. At the global level, and mostly in the developing countries, rapid economic growth and friendly business environment are heavily used for city branding purposes (Vanolo 2017), symptomatically imported in post-socialist cities, as the case of Timișoara shows.

This paper is based on a single-case study approach. Its theoretical contribution mainly consists in bridging the gap between the literature on city branding and the critical study of urban development. Our findings could contribute to further empirically oriented research on the consequences of branding discourses on urban development and city management. We have seen that many disparate elements are used to construct the branding identity of the city. The result is often an unstable, even contradictory mélange of images and representations of Timisoara, which result from the ad-hoc production of branding discourses. These discourses are open to adaptation, but also to contestation, showing signs of disruption through the contact with the concrete experiences provided by the city. Such cases signal how urban identities are transformed by global and regional economic and political fluxes and how specific urban identities are forged as a response to globalization and embedded in particular regional and local identities. Nevertheless, globalization (and Europeanization) does not always weaken local spatial identities, but it also tends to reinforce some forms of localism. Despite such possible evolutions, the norm in branding remains the seeking of a monolithic place identity, in which "place branding not only disregards the complexity of place identities but also disregards its own influence on identity formation" (Kavaratzis and Hatch 2013: 74).

What catches the attention in the case of Timișoara is how the narratives of urban development are produced in the monthly publication of the city council and especially the ways in which city growth is used as a branding tool. This paper sought to reveal the articulation of branding and urban development discourses as this operates in the case of Timișoara. At the same time, this case is also relevant in a comparative perspective for a broader category of post-socialist cities, especially for those which have adopted an urban development and city branding discourse linked to the idea of a regional and global competition between cities. On one hand, we demonstrate that the urban development discourse is played along the conventional line of development followed by the majority of post-socialist cities. We have called this process 'the normalization of development'. On the other hand, we have pointed to specific contradictions and incoherencies which undermine this discourse. By seeing branding as a "politically constituted practice" (Johansson 2012), we have connected branding practices to specific development visions produced by city authorities. We have illustrated how branding is used in a post-socialist city and we have indicated how a circular link between development and branding is produced, with the idea of rapid urban development standing as its main signifier. 


\section{Acknowledgements}

We would like to thank the three anonymous reviewers and the editors of JURA for their helpful suggestions for improving our paper.

\section{References}

BLANKE B., SMITH R. (eds.) (1999), Cities in Transition: New Challenges, New Responsibilities, Palgrave, London and New York.

BORÉN T., YOUNG C. (2013), Getting creative with the 'creative city'? Towards new perspectives on creativity in urban policy, International Journal of Urban and Regional Research 37 (5), 1799-1815.

ÇAGLAR A., GLICK SCHILLER N. (2018), Migrants and City-Making: Dispossession, Displacement, and Urban Regeneration, Duke University Press, Durham.

CHELCEA L., DRUŢĂ O. (2016), Zombie socialism and the rise of neoliberalism in postsocialist Central and Eastern Europe, Eurasian Geography and Economics 57 (4-5), 521-544.

CHOROMIDES C. (2018), The impact of the institutional framework quality on the ownership strategy. Evidence from EU foreign direct investments in South and Central Eastern Europe, Journal of Urban and Regional Analysis 10 (1), 25-60.

CRETAN R., GURAN-NICA L., PLATON D., TURNOCK D. (2005), Foreign Direct Investment and Social Risk in Romania: Progress in Less-Favoured Areas, in: Turnock D. (ed.), Foreign Direct Investment and Regional Development in East Central Europe and the former Soviet Union: A Collection of Essays in Memory of Francis 'Frank' Carter, Ashgate, Aldershot, pp. 305-348.

CRETAN R., TURNOCK D., WOUDSTRA J. (2008), Identity and multiculturalism in the Romanian Banat, Méditerranée: Journal of Mediterranean Geography 110 (1), 17-26.

DESFOR G., VESALON L., LAIDLEY J. (2011), Establishing the Toronto Harbour Commission and its 1912 Waterfront Development Plan, in: Desfor G., Laidley J. (eds.), Reshaping Toronto's Waterfront, University of Toronto Press, Toronto, pp. 49-74.

EUROSTAT (2018a), Gross domestic product (GDP) at current market prices by metropolitan regions, Retrieved from: https://data.europa.eu.

EUROSTAT (2018b), Eurostat Regional Yearbook 2018, Publications Office of the European Union, Luxembourg.

FORBES (2015), Forbes 40 cele mai bune orase pentru afaceri, editia 2015 (Forbes Best 40 cities for bussiness, in Romanian), Retrieved from: https://www.forbes.ro.

GENTILE M., TAMMARU T., VAN KEMPEN R. (2012), Heteropolitanization: social and spatial change in Central and East European Cities, Cities 29 (5), 291-349.

GROZA O., COUDROY DE LILLE L., PAFTALĂ-CIUBOTĂRITTA M. (2010), Spatial coordinates in building the brand image of regional metropolises. The case of lași municipality, Journal of Urban and Regional Analysis 2 (1), 3-13.

IANOȘ I., SÎRODOEV I., PASCARIU G., HENEBRY G. (2016), Divergent patterns of built-up urban space growth following post-socialist changes, Urban Studies 53 (15), 31723188.

ILIES A., GRAMA V. (2010), The external western Balkan border of the European Union and its borderland: premises for building functional transborder territorial systems, Annals for Istrian and Mediterranean Studies. Series Historia et Sociologia 20 (2), 457-468.

ILIES A., DEHOORNE O., ILIEȘ D. C. (2012), The cross-border territorial system in Romanian-Ukrainian Carpathian area. Elements, mechanisms and structures generating premises for an integrated cross-border territorial system with tourist function, Carpathian Journal of Earth and Environmental Sciences 7 (1), 27-38.

JOHANSSON M. (2012), Place branding and the imaginary: the politics of re-imagining a garden city, Urban Studies 49 (16), 3611-3626. 
"Little Vienna " or " European Avant-Garde City ? "Branding Narratives in a Romanian City

KAVARATZIS M., HATCH M. J. (2013), The dynamics of place brands: an identitybased approach to place branding theory, Marketing Theory 13 (1), 69-86.

KOSTINSKIY G. (2001), Post-socialist cities in flux, in: Paddison R. (ed.), Handbook of Urban Studies, Sage, London, pp. 451-465.

LÄHDESMÄKI T. (2014), European Capital of Culture designation as an initiator of urban transformation in the post-socialist countries, European Planning Studies 22 (3), 481497.

LEITNER H., PECK J., SHEPPARD E. (eds.) (2007), Contesting Neoliberalism. Urban Frontiers, The Guildford Press, New York and London.

LUCARELLI A. (2018), Place branding as urban policy: the (im)political place branding, Cities 80, 12-21.

LUCARELLI A., BERG P. O. (2011), City branding: a state-of-the-art review of the research domain, Journal of Place Management and Development 4 (1), 9-27.

MĂDROANE I. D. (2012), The role of multiculturalism in the discursive rescaling of an Eastern European city, Mobilities 7 (1), 33-52.

MARCIŃCZAK S., GENTILE M., RUFAT M., CHELCEA L. (2014), Urban geographies of hesitant transition: tracing socioeconomic segregation in post-Ceaușescu Bucharest, International Journal of Urban and Regional Research 38 (4), 1399-1417.

METAXAS T. (2010), Place marketing, place branding and foreign direct investments:

Defining their relationship in the frame of local economic development process, Place Branding and Public Diplomacy 6 (3), 228-243.

MORGAN N., PRITCHARD A. (1998), Tourism Promotion and Power: Creating Images, Creating Identities, John Wiley \& Sons Ltd., London.

PADDISON R. (1993), City marketing, image reconstruction and urban regeneration, Urban Studies 30 (2), 339-349.

PECK J., THEODORE N. (2015), Fast Policy: Experimental Statecraft at the Thresholds of Neoliberalism, University of Minnesota Press, Minneapolis.

PECK J., TICKELL A. (2002), Neoliberalizing space, Antipode 34 (3), 380-404.

PICKLES J., SMITH A. (eds.) (1998), Theorising Transition: the Political Economy of Post-Communist Transformations, Routledge, London.

SCHNEIDER-SLIWA R. (2006), Global and local forces in cities undergoing political

change, in: Schneider-Sliwa R. (ed.), Cities in Transition: Globalization, Political Change and Urban Development, Springer, Dordrecht, pp. 1-8.

SELLAR C. (2013), Europeanizing Timisoara: neoliberal reforms, continuity with the past, and unexpected side effects, GeoJournal 78 (1), 1-19.

SMITH A., ROCHOVSKÁ A. (2006), Neo-liberalism and post-socialist urban transformations: poverty, inequality and the city, Acta Geographica Universitatis Comenianae 48, 43-54.

SMYTH H. (2005), Marketing the City: The role of Flagship Developments in Urban Regeneration, Routledge, London and New York.

STANILOV K. (ed.) (2007), The Post-Socialist City: Urban Form and Space Transformations in Central and Eastern Europe after Socialism, Springer, Dordrecht.

STENNING A., SMITH A., ROCHOVSKÁ A., ŚWIATEK D. (2010), Domesticating NeoLiberalism: Spaces of Economic Practice and Social Reproduction in Post-Socialist Cities, Wiley-Blackwell, Oxford.

SYKORA L. (2009), Post-socialist cities, in: Kitchin R., Thrift N. (eds.), International Encyclopedia of Human Geography, Elsevier, Oxford, pp. 387-395.

SZONDI G. (2007), The role and challenges of country branding in transition countries: The Central and Eastern European experience, Place Branding and Public Diplomacy 3 (1), 820.

TIMIȘOARA MUNICIPALITY (2010), Plan Integrat de Dezvoltare - Polul de creştere Timişoara (Integrated Development Plan - Timișoara Growth Pole, in Romanian), Retrieved from: http://www.primariatm.ro. 
TIMIȘOARA MUNICIPALITY (2011), Timișoara - Studiu de economie urbană (Timișoara - Study of urban economy, in Romanian), Retrieved from: http://www.primariatm.ro. TIMIȘOARA MUNICIPALITY (2012), Planul urbanistic general (Timișoara Master Plan, in Romanian), Retrieved from: http://www.primariatm.ro.

TIMIȘOARA MUNICIPALITY (2017), Monitorul Primăriei Municipiului Timişoara 20132017 (Timișoara Municipality Monitor, in Romanian), Retrieved from: http://www.primariatm.ro. TIMIȘOARA MUNICIPALITY (2018), Strategia Integrată de Dezvoltare Urbană 20152020 (Integrated Strategy of Urban Development 2015-2020, in Romanian), Retrieved from: http://www.primariatm.ro.

TIMIŞOARA MUNICIPALITY (2019), Timișoara 2021. Capitală Europeană a Culturii (Timișoara 2021. European Capital of Culture, in Romanian), Retrieved from: http:// www.timisoara2021.ro.

TURSIE C. (2017), Culture-led urban regeneration of industrial derelict places. Case study: Paltim Hats Factory of Timișoara - A Cultural Social Enterprise, RAIS Journal for Social Sciences 1 (1), 7-23.

VANOLO A. (2017), City Branding: The Ghostly Politics of Representation in Globalising Cities, Routledge, London and New York.

VESALON L. (2010), Populism şi neoliberalism în discursul modernizării statului (in Romanian), in: Gherghina S., Mişcoiu S. (eds.), Partide şi personalităţi populiste în România postcomunistă, Institutul European, laşi, pp. 191-232.

VOICULESCU S., JUCU I. S. (2016), Producing urban industrial derelict places: The case of the Solventul Petrochemical Plant in Timișoara, European Urban and Regional Studies 23 (4), 765-781.

VOICULESCU S., CRETAN R., IANĂŞ A. N., SATMARI A. (2009), The Romanian Postsocialist City: Urban Renewal and Gentrification, West University of Timişoara Press, Timişoara.

YAO Y., LU Y., WANG G., DONG Y., WANG H. (2018), Relations between global city connectivity of the primary city and the size national economy, Journal of Urban and Regional Analysis 10 (1), 5-23.

Initial submission: 04.01.2019

Revised submission: 29.03.2019

Final acceptance: 06.05.2019

Correspondence: Department of Geography, West University of Timişoara, 4 V. Parvan Blv., 300223, Timișoara, Romania.

Email: remus.cretan@e-uvt.ro 


\title{
TESTING THE NEW URBANISM PRINCIPLE OF SUSTAINABLE TRANSPORT IN THE CONTEMPORARY REDEVELOPMENT PROJECTS. LESSONS FROM CLICHY-BATIGNOLLES IN PARIS AND THE STATION AREA IN LODZ
}

\author{
Monika Maria CYSEK-PAWLAK \\ Lodz University of Technology, Lodz, Poland
}

\begin{abstract}
As accessibility becomes a basic need of modern society, the issue of sustainable transportation continues to gain importance. On the large scale, it concerns interconnecting cities and metropolises, and, on a smaller scale, it refers to connection networks for pedestrians, cyclists and other means of public transport. The study aims to assess the importance of sustainable transport as a principle of New Urbanism in contemporary redevelopment projects. It introduces possible ways of implementing these principles, as well as dangers coming from misunderstanding them. The approaches and methods used in this article combine field studies conducted during the research trips desk research and interviews with professionals at various stages of two urban renewal projects - Clichy Batignolles (France) and the main train station area in Lodz (Poland). The study revealed the strategic role of rail line redevelopment projects in both rebuilding the continuity of the urban fabric (Clichy Batignolles) and in creating a new centrality for an area with attractive cultural activities and services (Lodz). As urban project timeframes are often long, both case studies show that high flexibility and the ability to adapt investments to changing conditions are often required. Nevertheless, the realization of the key infrastructure elements should be maintained all along. Furthermore, functional diversity can provide an important support for the sustainability of the project as it ensures the quality of urban tissue through height level representative public projects, thereby giving the area in question a new image. As exemplified by the housing policy in France, the distribution of functions can also serve as a pertinent response to the strategic needs of the entire agglomeration as well as a useful solution to local problems. One of the most crucial elements of redevelopment projects is the implementation of sustainable transportation that provides quick and comfortable connections by various means of public transport within different urban scales: metropolises, cities, districts and the city. As an element of sustainable urban policy, an effective public transportation network in the inner city should be supported by the limitation of car park ratio for non-residents within the redevelopment project. Altogether, the impact that other New Urbanism principles exert on developing urban structures is a pertinent question. Today, the real challenge for this movement has moved into the city, rather than on the outskirts, as in the past.
\end{abstract}

Key Words: new urbanism, sustainability, Clichy Batignolles, Lodz.

\section{Introduction}

The immediate association of the New Urbanism movement is the idea of pedestrian-oriented urban patterns. This development design is adapted for human-scale endeavors, with the aim of restoring city centers by reconfiguring sprawling suburbs (Talen 2013). To that end, a range of environmentally-friendly transit alternatives referred to as 'sustainable transportation' in the title. Both international organizations (European Communities Commission 1993, World Bank 1996, WBCSD 2004, International Energy Agency 2009, European Commission 2011) and individual researchers have coined similar definitions of mobility. This article assumes that sustainable transportation refers to efficient solutions in the context of environmental, social, economic, and spatial aspects. 
In order to create a green mobility system, broader planning projects that include various aspects of sustainable development are necessary. The Congress for the New Urbanism (2000) suggests that a number of guidelines defined in their charter of principles be applied to modern urban developments, which are currently largely monopolized by cars. As Calthorpe (2000: 68) stressed, "the real goal, of course, is improving people's mobility and access, not just reducing auto congestion. And this depends more on promoting different land-use patterns than building new roads". Even simple decisions such as locating everyday destinations closer to the workplace or home can be perceived as an effective strategy. The proponents of New Urbanism stress that public spaces (including roads) are too important for the community to be taken up by cars, and they should instead serve more to human needs (Schuyler 1997: 346). The debates of such forerunners as Krier (2009), and Calthorpe $(1993,2000)$ should also be mentioned here. Their arguments bear upon the work of Kunstler (1993), Farr (2008), Talen (2008), Speck (2012), and Langdon (2017). There are also studies that have found positive correlations between travel mode and spatial design elements such as mixed uses programming or density (Frank and Pivo 1994, Cervero 1996, Cervero and Radisch 1996, Cervero and Kockelman 1997, Moudon et al. 1997, Crane and Crepeau 1998, Boarnet and Crane 2001, Greenwald and Boarnet 2002, Saelens et al. 2003, Rodríguez et al. 2007).

An analysis of sustainable transportation, perceived as one of the principles of New Urbanism, cannot overlook the notion of transit-oriented development (TOD). This approach is considered to be a model that prevents auto-dominated landscapes (Ellis 2002, Lin and Gau 2006). TOD is associated with high density design around hub stations (Ma et al. 2018). Calthorpe (1993: 56) defined TOD as: "a mixed-use community within an average 2000-foot [approximately $600 \mathrm{~m}$ ] walking distance of a transit stop and core commercial area. TODs mix residential, retail, office, open space, and public uses in a walkable environment, making it convenient for residents and employees to travel by transit, bicycle, foot, or car." Transit-oriented development has also attracted attention in the scientific literature (Cervero and Sullivan 2011, Dorsey and Mulder 2013, Papa and Bertolini 2015, Qviström and Bengtsson 2015).

Based on the literature quoted above, this article presents original conclusions about the influence of sustainable transportation as an element of the comprehensive New Urbanism approach to the renewal of degraded post-industrial areas. The presented research aims to assess the significance of green mobility in contemporary redevelopment projects in the context of other elements that, according to the CNU definition, define the space. The article sets out possible methods of implementing sustainable transportation and highlights the potential threats that a mistaken interpretation may lead to (an excess of road infrastructure over public spaces designed for pedestrians).

\section{Methodology}

The article is part of a larger research project developed by the author devoted to the principles of New Urbanism. The study aims to present a comprehensive assessment of the impact that the key principles of the movement have on the redevelopment of post-industrial areas today. The methodology discussed below has therefore been complemented by a broader study of New Urbanism itself. Elements of literature review relevant to sustainable transportation have been presented in the introduction.

The methodology used in the article comprises case studies allowing, as Tellis (1997) underlines, to gather together different types of data, and enabling the understanding of the local context. Moreover, the comparative approach adds to the method more universality (Faure 1994). Finally, the comparative methodology of including international cases (Nadin 2012), places the observations in a national context, thereby helping to define guidelines for state-wide policy. 
Testing the New Urbanism Principle of Sustainable Transport in the Contemporary Redevelopment Projects. Lessons from Clichy - Batignolles in Paris and the Station Area of Lodz

The study involved four stages, which took place in various locations over the last few years. During the first stage, the research method and criticism used were based on Polish and French literature connected to the subject. Working materials and project documents were obtained from the participants of the analyzed projects. The desk research also referred to statistical data obtained from the Central Statistical Office in Poland (GUS) as well as the National Institute of Statistics and Economic Studies in France (INSEE). Analysis of strategic planning documents such as those related to the operational urbanism and city council resolutions, allowed to reveal the execution of urban policy within the examined areas. These analyses were followed by observations which allowed to define the walkability of the analyzed zone, its limits, and connectivity with the surrounding urban fabric and the heart of the city (comfort, directness and time framework). The analysis was performed during a research stay at the Institute for Town and Regional Planning at the University Paris-Sorbonne in September 2017 , and in Lodz, during the work at the University of Technology. The aim of this stage was to verify the data gathered in the first part of the research project in situ, and to make an empirical assessment of the transformation in the area. The GIS was based on the Urban Atlas data, and, next, the Autodesk AutoCAD software was used. At the third stage, the data gathered underwent a comparative analysis. The basic elements of comparison were:

- the location of the project within the entire urban tissue;

- the timeframe of implementing the objectives;

- the understanding of sustainable transportation in urban policy;

- the scale of the investments (how the need for accessibility between the site and other elements of the city center, and between the site and housing areas on the outskirts of the agglomeration should be taken into consideration);

- the proposed modality transport and its capacity (which mode of transport the project gives priority to, what the consequences of this decision are);

- the parking policy implemented within the site, in the context of the strategy adopted for the urban area;

- the ratio of roadways to the total area of the site.

Research approaches included quantitative as well as qualitative studies depending on the examined issue. The results were presented in tables defining the main urban indicators, as well as the representativeness of studied cases. The above analysis was used to compare the Clichy-Batignolles area in Paris with the redevelopment project of the station district in Lodz. Both projects are at different stages of completion. On the one hand, this allows us to clearly see the dynamics of implemented changes and include our conclusions in our own project to improve it. On the other hand, it introduces a certain level of complexity. This aspect was taken into consideration during the fourth and final stage of the study: formulating conclusions in the context of possible research and practical perspectives. The chosen case studies were selected to illustrate current tendencies in Western and Central Europe. The comparative study allows, therefore, to define some general rules for this part of Europe. These guidelines are all the more valuable because many European urban systems, especially those from Eastern and Central Europe, use French examples, and they adopt them to their own needs, as it can be observed in former Polish strategies (Skalski 2009). Some of identified tendencies could be perceived as urban Europeanization (Coudroy de Lille 2016).

\section{Results}

Strategic position on the rail line as a basis for reevaluating the degraded zone

The site of Clichy-Batignolles (Fig. 1) is located in the northwest part of Paris, in the 17th arrondissement; it spans 133 acres (54 ha). This new development around Martin Luther King Park aims to connect neighborhoods that were historically separated by the railway network. 


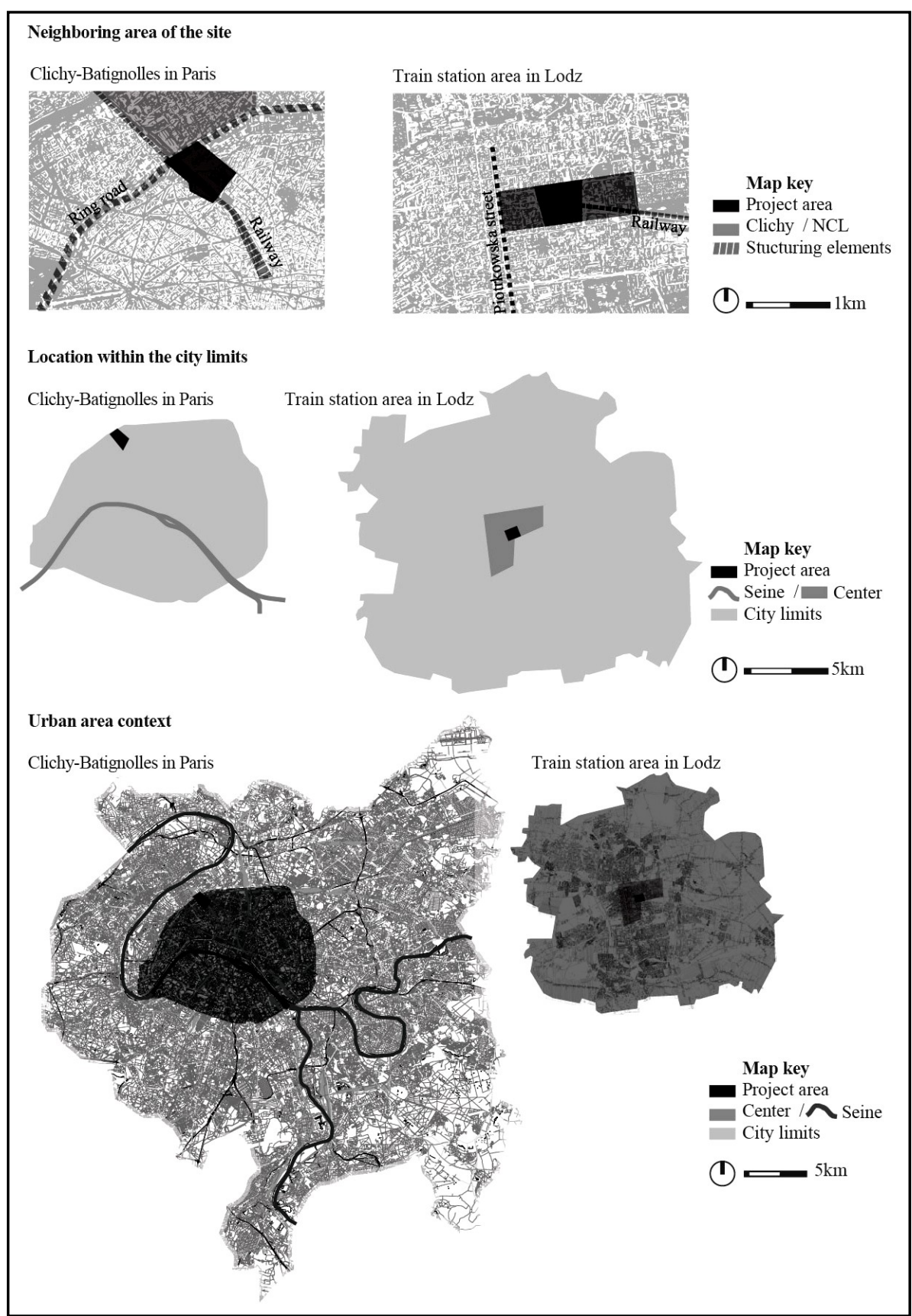

Fig. 1- Neighboring area of the site

Source: developed by the author based on the strategic planning documents of Paris and Lodz 
Testing the New Urbanism Principle of Sustainable Transport in the Contemporary Redevelopment Projects. Lessons from Clichy - Batignolles in Paris and the Station Area of Lodz

The project was conceived as a sort of bridge between the more bourgeois zone in the west (the historical core of Paris) and the working-class area in the north (the suburban commune of Clichy). It rebuilds the continuity of urban fabric in a zone that has traditionally been devoted to logistics: mainly heavy transportation. Apart from the tracks of Saint-Lazare, the Paris ring road also poses a barrier: the Boulevard Peripherique. The Batignolles site includes a marshalling yard located on Petite Ceinture ${ }^{1)}$. After the redevelopment of the rail infrastructure, the PontCardinet station was preserved, served by the Transilien Line $L$ trains (Paris-Saint-Lazare network), and the technical tracks were reduced to the minimum. The industrial heritage of the site is not only limited to the railway, but also to buildings such as the opera warehouse or the power plant.

The area in Lodz, spanning 94 acres (38 ha), also includes several post-industrial buildings The emblematic elements include: a heat and power plant (EC1) that has recently been turned into an open Science and Technology Museum, a conference-and-arts center, and a planetarium. As with Clichy-Batignolles, the analyzed area was released from the infrastructure zone. In Lodz, the alliance between the city and the rail took the form of a modern multimodal station, which was partially moved underground. The Lodz Fabryczna train station has always been the most important element of the circular railway line ${ }^{2)}$, as its most central terminus. The area in the immediate vicinity of the train station in the historical center was recognized by the city authorities as an area of strategic redevelopment in the New Center of Lodz (NCL) within the regeneration project (Table 1). The NCL is divided into three sections that differ in terms of building types. The renewal of the historical city block was planned in the area closest to the historical city center, i.e. to ul. Piotrkowska. The elements related to transportation and culture will dominate around the station. To the east, the layout will be closed by a housing and commercial program. The presented study focuses on the central zone.

Location indicator

Table 1

\begin{tabular}{|c|c|c|c|}
\hline \multirow{3}{*}{ Indicator } & Variable & $\begin{array}{c}\text { Clichy- } \\
\text { Batignolles }\end{array}$ & $\begin{array}{c}\text { Train station } \\
\text { area } \\
\text { in Lodz }\end{array}$ \\
\hline \multirow{4}{*}{ Location } & Brownfield site & $\bullet$ & $\bullet$ \\
\cline { 2 - 4 } & $\begin{array}{c}\text { Heart of agglomeration } \\
\text { whose character was changed }\end{array}$ & $\bullet$ & $\bullet$ \\
\cline { 2 - 4 } & $\begin{array}{c}\text { Old spatial barriers removed in order } \\
\text { to rebuild historically separated } \\
\text { neighborhoods }\end{array}$ & $\bullet$ & \\
\hline
\end{tabular}

The complexity of the urban project timeframe: changes of ideas, conditions, and actors

The transformation of the station district in Lodz started out when the city, five years after closing down the power plant, bought back the EC1 buildings (2005). The initial contracts between the municipal authorities and the Polish Railway Group (PKP) were signed a year later. Rob Krier, a town planner known for a fondness for classical aesthetics, began

1) Initially, Petite Ceinture was only a freight line, and it later gradually started accepting passengers.

2) The circular railway line surrounds the historical core of Lodz, in a way similar to Petite Ceinture, and it serviced both passengers and cargo. 
developing a plan to manage the area. The entire project was solidified when the Minister of Infrastructure announced that in five years' time, the construction of the Polish high-speed rail would start, and that it would go through Lodz (2008). After consultations with the engineers, decision-makers at the ministerial level decided that a comprehensive redevelopment of the Lodz Fabryczna station, which would include a cross-city tunnel underground, was needed ${ }^{3}$. The situation became more complicated when, after the minister was replaced, the high-speed rail idea was abandoned. Later, the authorities decided to revoke the cancellation, and to postpone the project instead. The cancellation of the rail project, however, did not hamper the redevelopment of the station zone in Lodz, and the station was closed down that year. In the meantime, work continued on the master zoning plan (MPZP) in the station district. The plan needs to be adapted in order to accept and include some of the project decisions made while drawing up the train station project (Resolution No. III/40/14 \& III/41/14 of the City Council in Lodz 2014). On the assumption that the area under development would become a live revitalization lab, Poland registered the Lodz's application to hold the International Specialized EXPO 2022 precisely in this area. The proposed topic was: City Re-Invented (2015). However, Buenos Aires' victory meant that Lodz's chance for promotion, and the development that such a major event would facilitate, was lost (2017). In the meantime, the new Lodz Fabryczna train station was opened and a plot in the area, the most expensive one in the history of Lodz, was sold to a private investor (2016). Gradually, EC1 buildings are being opened up having been adapted to their new functions. Work on building a cross-city tunnel continues, but only concerning a conventional rail project. The end of the renovation is planned for 2022. If the Polish high-speed rail is to be finished around 2028/30, then another tunnel under the city will have to be built before then. In short, the whole project of developing the station area has already been underway for 13 years. The key elements of the project should be finished within 25 years.

The timeframe of Clichy-Batignolles is similar to that of Lodz (Table 2), as, according to the timetable, its strategic elements will take 20 years to come to fruition - and given that it is now in its 18th year of implementation. After the official announcement by the Council of Paris that an exemplary eco-district (2002) would be created, an attempt was made to host a strategic mass event in the investment area, in that case - the Olympic Games in 2012. It was also then that the city began buying back plots from the French railway company (SNCF). A year later, designers started their work under the aegis of an architect and urban planner, François Grether, and a landscaper, Jacqueline Osty (2004). The decision to choose London to host the Olympic Games meant that the plans for the Olympic Village needed to be altered. The project team and the ideas behind the development around the central park remained the same (2005). The Prime Minister sequentially approved moving the railway activity to the north (2006) and opening the first part of Martin Luther King Park (2007). Finally, it was announced by the national government and the municipal authorities that the building of the High Court (Tribunal de Grande Instance) would form part of the project (2009). It is worth stressing that an operational plan for Clichy-Batignolles (ZAC) was designed at the same time. At the beginning of the next decade, there was some significant construction work going on: the regional rail system (RER) was covered and the first apartment block in the area was completed (2012). Today, almost all of the eastern part of the buildings are already operational, and the remaining buildings, including the key infrastructure, are to be finished gradually by 2020 (T3 tram, extension of the $14^{\text {th }}$ metro line).

\section{In search of sustainability in the urban functional plan}

One feature of the Clichy-Batignolles project is the importance of the area around the central Martin-Luther-King Park, whose target area should reach 25 acres (10 ha), and half has

3) The Lodz Fabryczna station has traditionally been a terminal station, so the trains need to go in and reverse out again in order to proceed, which obviously takes more time. 
Testing the New Urbanism Principle of Sustainable Transport in the Contemporary Redevelopment Projects. Lessons from Clichy - Batignolles in Paris and the Station Area of Lodz

Timeframe indicator

Table 2

\begin{tabular}{|c|c|c|c|}
\hline \multirow{2}{*}{ Indicator } & Variable & Clichy-Batignolles & $\begin{array}{c}\text { Train } \\
\text { station area } \\
\text { in Lodz }\end{array}$ \\
\hline \multirow{4}{*}{ Timeframe } & $\begin{array}{c}\text { Completion of the initial project idea } \\
\text { for the project }\end{array}$ & - & - \\
\cline { 2 - 4 } & $\begin{array}{c}\text { Realization of key infrastructure } \\
\text { elements }\end{array}$ & in progress & in progress \\
\cline { 2 - 4 } & $\begin{array}{c}\text { Time from the project initiation to the } \\
\text { present day }\end{array}$ & 18 years & 13 years \\
\cline { 2 - 4 } & Total estimated duration of the project & 20 years & 25 years \\
\hline
\end{tabular}

already been opened. It constitutes $18.5 \%$ of the whole area of the development. This park, with its various leisure activities, will be the largest one in northwestern Paris. Another element that is characteristic of the Clichy-Batignolles site is the role of public buildings in the project: $31.5 \%$ of the total floor area. The flagship investment is the courthouse designed by Renzo Piano. In addition to the typical Res Publica, there are also many urban services in the area (a recycling center, bus and coach parking and a concrete plant). All these elements are concentrated close to the ring road and railroad tracks, so as to reduce their nuisance. A dominant component of the built-up area is housing, whose percentage is slightly above that of public buildings in the area: $34.5 \%$. In accordance with national and local laws in France, a variety of sizes, standards and typology of apartments was guaranteed in the project (as reported by the investor, Clichy-Batignolles will ultimately offer $50 \%$ social housing, $20 \%$ capped-rent housing and $30 \%$ housing at market prices). As well as regular apartments, there are housing units for university students and young working people, and rooms for dependent seniors being offered. While analyzing the issue of sustainable transportation in the projects, the share of roadways in the site, where the impermeable surface makes up to only $12 \%$ of the total development area, is worth stressing (while total roadways make up to $16 \%$ of the site area).

The investment in Lodz has a similar total area of mixed-use development - 5381955 square feet (cca. $500000 \mathrm{~m}^{2}$ ) - as that in the French site (Fig. 2). However, its share of roadways in the development plan is much larger $-35 \%$. An analysis of the land use also shows a significant share of open public spaces, reaching almost $14 \%$ of the area. It should also be noted that these areas are slowly being delivered by the city (a tender for the New Center of Lodz square project, a.k.a. Rynek Kobro, began recently). In the vicinity of the Lodz Fabryczna train station is the historic Stanisław Moniuszko Park, constituting $6 \%$ of the entire area. The eco-friendly nature of the development is regulated in the master zoning plan, which states that $9 \%$ of the area inside the city blocks, including green roofs, will ultimately be designated for green areas (in comparison, it is only $4 \%$ in Clichy-Batignolles). A study of the urban tissue in Lodz clearly shows the ultimate domination of office use: $43 \%$. While these buildings are under construction, many public buildings are already operational in the area. It is with the public buildings that the city's modern identity is being constructed: the Lodz Fabryczna train station and the EC1 heat and power plant (Table 3). As opposed to the investment in Paris, a greater ratio of services (including retail and facilities) is planned on the Lodz site. On the other hand, the role of apartment buildings, in comparison with other functions, is relatively small. 


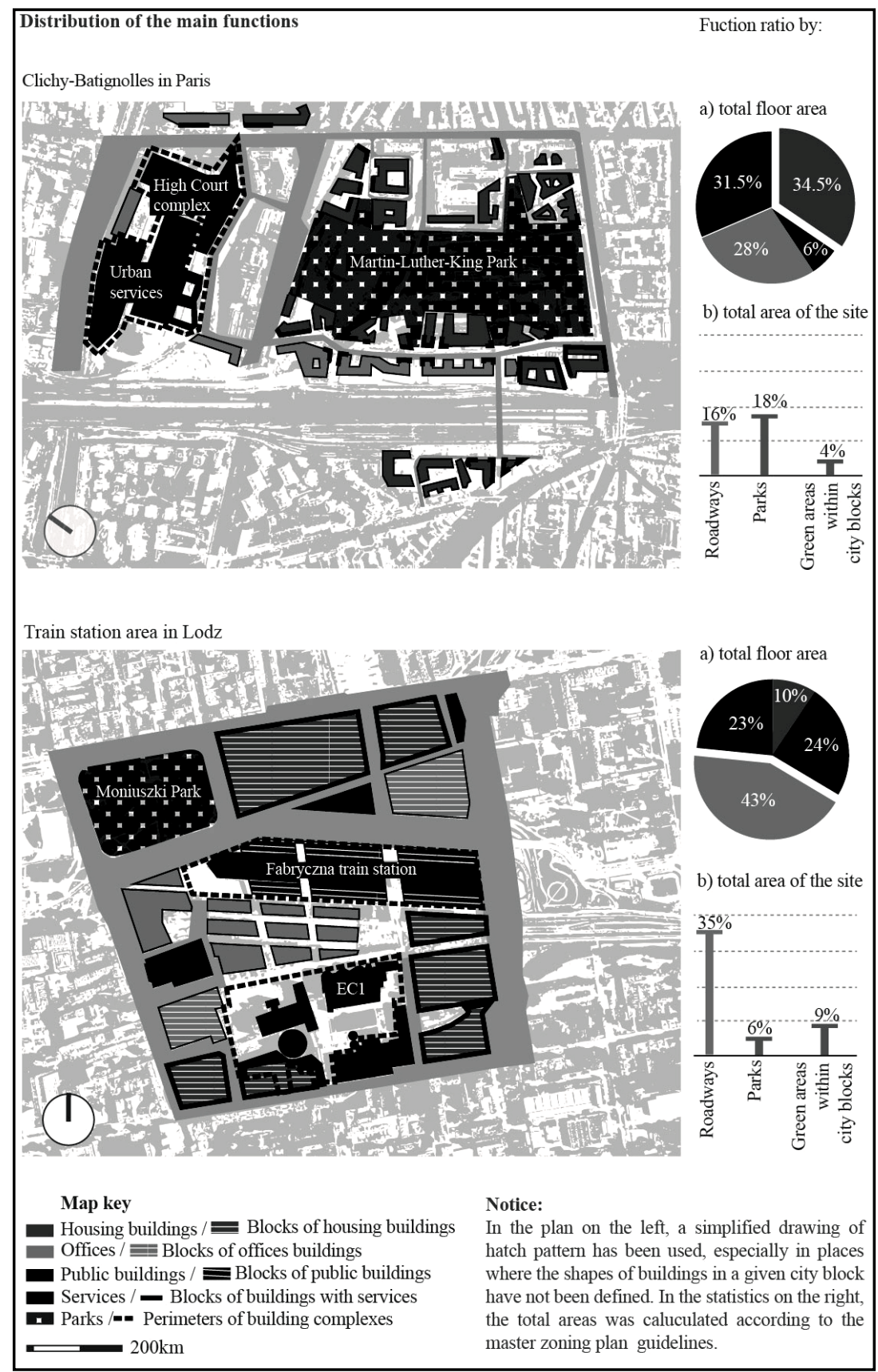

Fig. 2 - Distribution of main functions

Source: developed by the author based on Paris Batignolles Aménagement and Municipal Urban Agency data 
Testing the New Urbanism Principle of Sustainable Transport in the Contemporary Redevelopment Projects. Lessons from Clichy - Batignolles in Paris and the Station Area of Lodz

Distribution function indicator

\begin{tabular}{|c|c|c|c|}
\hline Indicator & Variable & $\begin{array}{c}\text { Clichy- } \\
\text { Batignolles }\end{array}$ & $\begin{array}{c}\text { Train station area } \\
\text { in Lodz }\end{array}$ \\
\hline \multirow{6}{*}{$\begin{array}{c}\text { Distribution } \\
\text { function }\end{array}$} & Housing use dominance & $\bullet$ & - \\
\cline { 2 - 4 } & $\begin{array}{c}\text { Office use dominance } \\
\text { agglomeration through the } \\
\text { policy for whole } \\
\text { dominant use }\end{array}$ & - & $\bullet$ \\
\cline { 2 - 4 } & $\begin{array}{c}\text { Public services which } \\
\text { mitigate environmental } \\
\text { pollution at the site }\end{array}$ & - & - \\
\cline { 2 - 4 } & Flagship investment & $\begin{array}{c}\text { Courthouse } \\
\text { (public } \\
\text { investment) }\end{array}$ & $\begin{array}{c}\text { Lodz Fabryczna } \\
\text { train station and the } \\
\text { EC1 heat and } \\
\text { power plant (public } \\
\text { investment) }\end{array}$ \\
\hline
\end{tabular}

The different interpretation of sustainable transportation

The start of the project in Lodz is closely related with the announcement of key changes in the city's and country's transportation policy. As a result, significant investments in the highway sector were supposed to be complemented by a strategic high-speed railway project. In Lodz, the change in the approach to transportation was shown through the city's zoning solutions themselves. The motto of the new district's project - Station Down, Culture Up - reflects the changes in the design tendencies and a move towards pedestrian-oriented solutions. The choice of Rob Krier, a pioneer of New Urbanism, as the main urban planner was therefore not a coincidence. The decisions to tear down the barrier that divided the city and to move the railway area underground and to modernize it were supposed to allow for a new functional and spatial quality to emerge. Ultimately, the modern multimodal station was created at the cost of tearing down the previous station completely. The railway tracks were moved underground, though only in the eastern part of the site. For now, Lodz Fabryczna still remains a terminus station. The station, now adapted to serve 200000 passengers a day, is the largest hub in that part of Europe. Unfortunately, its capacity potential remains unrealized, because the highspeed rail Poland project has not yet been introduced. The agglomeration rail network around the city is successively being extended. For example, the cross-town tunnel under the city for conventional rail is being developed. This will certainly lead to an increase in railway connections through Lodz Fabryczna, as the trains will be able to go through the station closest to the city center, without having to turn in order to move back in the direction it came from. In the area of the hub, there is also a central bus station, and it is accessible by bus and tram. There are also city bike stations in the vicinity. These investments are located in the western part and they seem somewhat weighed down by the complex road infrastructure in the eastern part. Four-lane streets now stretch from the station towards one-lane streets in the city center, which is not a strategic arterial junction in the city. The quality of the spatial solutions also varies: on the one hand, living streets known as woonerfs are being built, but, on the other hand, complicated interchanges and enormous road systems are appearing that are very difficult or even impossible for pedestrians to cross. A comparison between the former railway area and the modern road layout clearly shows that the spatial barrier has remained essentially unchanged, the only difference being it is now no longer the railway tracks that create it, but the roads. 
In the case of Clichy-Batignolles, the design of the roads appears more uniform (Table 4), with the exception of the ring road transit. Throughout the whole area, the speed limit has been reduced to $20-30 \mathrm{~km} / \mathrm{h}$ (12.5-18.5 $\mathrm{mph}$ ), which influences the quality of the sidewalks (apart from the ring road). The sense of security is strengthened by the greenery that lines the paths. In addition to creating about a dozen public bike stations, the city is now legally bound to devote $2.5 \%$ of the total area to bicycle parking. As well as the bicycle sharing system Velib, the car sharing Autolib is also available. In terms of mass transit, Clichy-Batignolles is served by the Metro line 13, RER (rapid transit rail) line $C$ and Transilien rail line $L$ (Fig. 3). The latter is connected with Gare Saint-Lazare, an important transport hub (the metro, RER, French railway company SNCF). The Pont-Cardinet station of Transilien rail line $\mathrm{L}$, which serves ClichyBatignolles, is frequented by an average of 9500 travelers per day (SNCF 2014 data). By 2019 , the connection with Saint-Lazare will have been strengthened by an extension of Line 14 of the metro, with two new stations planned to be located within the area of the site (Pont Cardinet and Porte de Clichy). Currently, line 14 carries 550000 passengers per day, and this figure should rise by $30 \%$ by 2020 , reaching 1 million in 2024, after its extension towards the north and south (these are the estimated figures of the Paris City Council and the department responsible for the issue). The investment has three strategic goals: relieving the overcrowded line 13, connecting Clichy-Batignolles with other parts of Paris, and creating a direct connection between the site and Gare de Lyon. The city is also carrying out the extension of tram line T3. Thanks to that, the Porte de Clichy station will be located in the square in front of the courthouse, where metro lines 14 and 13, the existing RER C line and the T3 tramline will all converge.

Transportation mode indicator

Table 4

\begin{tabular}{|c|c|c|c|}
\hline Indicator & Variable & Clichy-Batignolles & $\begin{array}{c}\text { Train station area } \\
\text { in Lodz }\end{array}$ \\
\hline \multirow{3}{*}{$\begin{array}{l}\text { Transportation } \\
\text { mode }\end{array}$} & $\begin{array}{l}\text { Pedestrian-oriented } \\
\text { policy }\end{array}$ & - & partial \\
\hline & $\begin{array}{l}\text { Transportation hub } \\
\text { within the project }\end{array}$ & - & $\bullet$ \\
\hline & $\begin{array}{c}\text { Coherence between the } \\
\text { size of the infrastructure } \\
\text { and the need of the } \\
\text { users }\end{array}$ & $\bullet$ & partial \\
\hline
\end{tabular}

The importance of the scale in transportation investments

As described above, the transportation investments connected with serving Clichy-Batignolles are aimed at creating faster and more comfortable connections between the site and the entire agglomeration. The Nouveau Grand Paris project will be a guarantee of this large-scale strategy. The extension of Line 14 is the first element of the automation of the underground, as planned in the project. The aim of Nouveau Grand Paris is to remove the inequalities in accessibility between individual city districts in Paris itself, and to towns in the suburbs, to ultimately create a sustainable environment. The program has been underway since 2013 and it includes improving the service of other means of public transport: buses, trams, rail services. Thanks to that, the Clichy-Batignolles investment will be accessible within less than 20 minutes from other major city center hubs (Châtelet-les-Halles and Gare de Lyon). On the one hand, the site is exploiting its location within the metropolitan triangle: La Défense, the central business district and Plaine Saint-Denis. On the other hand, it will be more easily accessible for the users of the suburban network of Saint-Lazare as well ${ }^{4}$.'

4) Not only will metro line 14 will be connected with the Saint-Lazare station, but also RER E will be extended towards the north. 
Testing the New Urbanism Principle of Sustainable Transport in the Contemporary Redevelopment Projects. Lessons from Clichy - Batignolles in Paris and the Station Area of Lodz

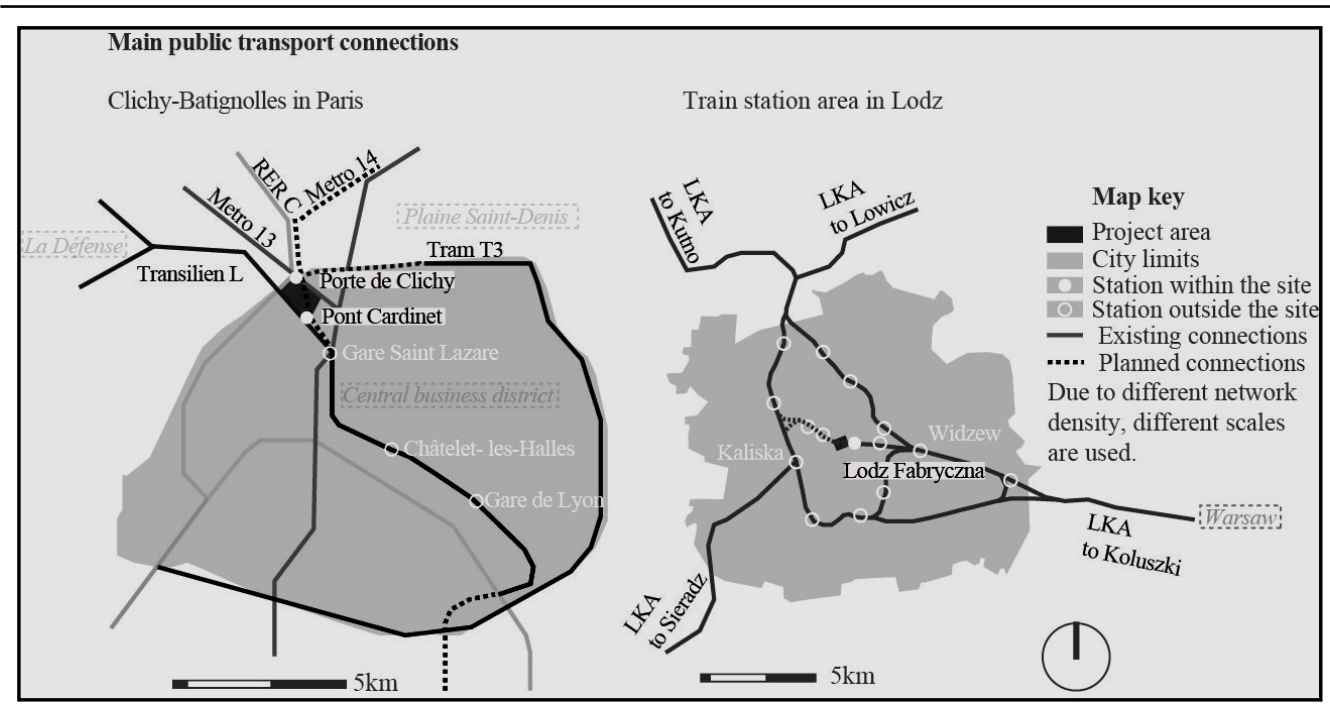

Fig. 3 - Main public transport connections

Source: developed by the author based on Paris Batignolles Aménagement and Municipal of Lodz data

The importance of the scale in transportation investments

As described above, the transportation investments connected with serving Clichy-Batignolles are aimed at creating faster and more comfortable connections between the site and the entire agglomeration. The Nouveau Grand Paris project will be a guarantee of this large-scale strategy. The extension of Line 14 is the first element of the automation of the underground, as planned in the project. The aim of Nouveau Grand Paris is to remove the inequalities in accessibility between individual city districts in Paris itself, and to towns in the suburbs, to ultimately create a sustainable environment. The program has been underway since 2013 and it includes improving the service of other means of public transport: buses, trams, rail services. Thanks to that, the Clichy-Batignolles investment will be accessible within less than 20 minutes from other major city center hubs (Châtelet-les-Halles and Gare de Lyon). On the one hand, the site is exploiting its location within the metropolitan triangle: La Défense, the central business district and Plaine Saint-Denis. On the other hand, it will be more easily accessible for the users of the suburban network of Saint-Lazare as well.

The size of the connections in Lodz cannot be compared, for obvious reasons. In any case, it is the quality of the connections between the site and the other elements in the city center, housing areas on the outskirts of the agglomeration, as well as other important urban settlements in Poland that is relevant. The project of the Lodz Fabryczna train station was accompanied by the idea of a high-speed rail line between Lodz and Warsaw, Poznan, and Wroclaw. As presented below, that project has been temporarily put on hold. In the meantime, a general renovation of the Lodz-Warszawa route has been carried out, with the aim of shortening the length of the journey down to 70 minutes (a section of about $140 \mathrm{~km}=87$ miles). The Lodz Agglomeration Railway (LKA) is, on the other hand, the basic investment on a regional scale, as it connects the neighboring towns and the individual districts in Lodz itself. The project's timeframe spans ten years and the end has been planned for 2020. Today, a significant section of it is already operational and it carries an average of 11760 passengers a day (LKA data from early 2018). As part of the LKA project, P\&R parking lots, bus stations and bike sharing stations will be located next to the train stations. The LKD stations which are 
located on the circle route should help alleviate the auto congestion, especially in the city center. Users will be able to leave their cars on the outskirts and reach the central station comfortably. A connection between the Widzew and Kaliska stations will create a shortcut in the existing network, and a cross-city tunnel is currently under construction between Fabryczna and Kaliska (Table 5).

Scale of connections indicator

Table 5

\begin{tabular}{|c|c|c|c|}
\hline Indicator & Variable & Clichy-Batignolles & $\begin{array}{c}\text { Train station area } \\
\text { in Lodz }\end{array}$ \\
\hline \multirow{3}{*}{$\begin{array}{c}\text { Scale of } \\
\text { connections }\end{array}$} & $\begin{array}{c}\text { Direct connection to the city } \\
\text { centre }\end{array}$ & in progress & in progress \\
\cline { 2 - 4 } & $\begin{array}{c}\text { Direct connection to the } \\
\text { agglomeration } \\
\text { transportation network }\end{array}$ & - & \\
\cline { 2 - 4 } & $\begin{array}{c}\text { Direct connection to the } \\
\text { national transportation net }\end{array}$ & - & \\
\hline
\end{tabular}

Car park ratio as a tool of sustainable urban policy

The general policy in Paris is to drastically limit the number of parking spaces. After an update in the local master plan (PLU), there is no longer a ratio of parking places that needs to be imposed, except for office use (since 2016). There are no constraints as to the number of parking places in public spaces (be it public squares or roadside parking places). However, an analysis of the Clichy-Batignolles structure clearly shows that parking places have been created mainly for residents rather than for employees, who are discouraged from commuting by car to that neighborhood. Regulations from the previous PLU and the operational development plan $(\mathrm{ZAC})$ were used to control the issue of parking.

Moreover, Paris Batignolles Aménagement, a local public company (SPL) responsible for conducting the development operation, after consulting a specialized design office, additionally registered the following ratio in the tender documentation, and later in the contract of sale (Cahiers des Charges de Cession de Terrain des actes de vente):

- $\quad$ offices : 0.353 car places for 1,075 square feet $\left(100 \mathrm{~m}^{2}\right)$ of floor area;

- $\quad$ commerce and services: 0.28 car places for 1075 square feet $\left(100 \mathrm{~m}^{2}\right)$ of floor area;

- $\quad$ housing: one car place per 1075 square feet $\left(100 \mathrm{~m}^{2}\right)$ of housing area.

In Clichy-Batignolles, a residential car park for 600 vehicles was created. It is operated by a semi-public company (Saemes). On the whole site, however, there will only be two car parks for non-residents, able to fit 200 and 250 spaces.

These numbers are far smaller than those on the Lodz site, where the Fabryczna station car park can hold 960 vehicles and it is accessible free of charge for all users. Next to it, another construction is planned with over 300 underground parking spaces. This is an element of a new square and underground road development that has just been started. However, the new neighboring office investments are failing to make full use of the possibilities that the master zoning plan presents. The plan regulates the parking place ratio (Table 6) as follows:

* housing: between 0.5 and 1 place per apartment;

* commerce: between 3 and 8 freely accessible places per 10750 square feet $\left(1000 \mathrm{~m}^{2}\right)$ of floor area; 
Testing the New Urbanism Principle of Sustainable Transport in the Contemporary Redevelopment Projects. Lessons from Clichy - Batignolles in Paris and the Station Area of Lodz

* $\quad$ public administration and offices: at least 3 places per 10750 square feet $\left(1000 \mathrm{~m}^{2}\right)$ of floor area.

Table 6

Car parking policy indicator

\begin{tabular}{|c|c|c|c|}
\hline Indicator & Variable & $\begin{array}{c}\text { Clichy- } \\
\text { Batignolles }\end{array}$ & $\begin{array}{c}\text { Train station area } \\
\text { in Lodz }\end{array}$ \\
\hline \multirow{3}{*}{$\begin{array}{l}\text { Car parking } \\
\text { policy }\end{array}$} & $\begin{array}{l}\text { Parking spaces quantity } \\
\text { limitation policy }\end{array}$ & $\bullet$ & 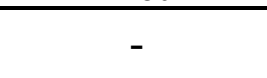 \\
\hline & $\begin{array}{l}\text { Parking created at the site } \\
\text { are mostly dedicated to } \\
\text { residents }\end{array}$ & • & - \\
\hline & $\begin{array}{l}\text { Parking created at the site } \\
\text { are mostly dedicated to } \\
\text { external users }\end{array}$ & - & • \\
\hline
\end{tabular}

\section{Discussion}

The results presented above yield new insights into the existing research in the field of sustainable transportation with aspects related to New Urbanism. An attempt was made to define efficient spatial solutions that would make it possible to (re)create landscapes that are not dominated by cars. Elements that improve mobility and accessibility, as defined by New Urbanism, were therefore the key.

In projects that rely on sustainable transportation, the location itself is extremely important. In both cases under analysis, the location along a degraded, post-railway line unlocked the new potential of the place, drawing on the existing modernized infrastructure. This approach is not only coherent with the idea of sustainable transportation, but also with urban regeneration. While the general positive accounts of New Urbanism principles, including the principle of sustainable transportation, are slowly becoming convincing (Fainstein 2000, Dierwechter and Coffey 2017), its value in redevelopment projects intra muros remains largely unexplored. Taking action within the central area of the urbanized environment is the contemporary adaptation of New Urbanism guidelines.

Given the value of the area, the timing of the investment is crucial. Since urban projects are generally thought of as long-term plans, it is rational that the timespan of the developments in Lodz and in Paris should stretch over a 20-25-year-long period. During this time, the investments are influenced by changes in political and economic circumstances. The basic ideas and decisions, however, should not be altered, especially those connected with sustainable transportation. Unfortunately, due to the prolongation of the Polish TGV program, this kind of change did somehow take place in Lodz. The development of high-speed rail in Poland was put on hold, even though it was supposed to pave the way for developments throughout the station area.

The implementation of the ideas behind sustainable transportation should include, on a large scale - interconnecting metropolises, cities, and districts with each other, and on a small scale - creating a network of connections within city blocks for pedestrians, cyclists, cars, and various means of public transport. The research complements the existing findings about the influence of the urban environment on the travel behavior (Joh et al. 2009, Marshall 2015) with aspects related to different scales of urban policy and mass transit. In the metropolis, these guidelines are achieved at the already discussed Nouveau Grand Paris project, and within the 
site - by the local master plan (PLU) and the operational development plan (ZAC).

In Lodz, although the idea of sustainable transportation is implemented in the agglomeration railway project, the guidelines included in the master zoning plan (MPZP) do not rise to the challenge. Attempts have been made to render the area around the station more accessible to cyclists, but the attempts were ultimately much smaller than the investments concerning car transportation. This is best illustrated by the domination of the roadway in the train station area in Lodz, which is twice as large as that in Clichy-Batignolles.

Parking policy is also relevant when assessing the level of sustainable transportation. In Paris, while the number of parking places for non-residents continues to be limited, a net of public transport is developing. In Lodz, on the other hand, significant parking areas are still being created in the new station developments, which are paid for by the country and they are free to all users. Those who have a choice will opt to reach the NCL by car rather than by the developing public transport. In Lodz, public network connections between the site and other elements of the city center, and between the site and the housing areas on the outskirts of the agglomeration, need to be facilitated.

The results presented by the article complement the existing research also in the relations between density, land-use diversity, and pedestrian-oriented designs on non-motorized travel (Cervero and Kockelman 1997, Talen 2013, Wohl 2017). So far, it has been assumed that the relations between these elements (Table 7) are statistically significant, but of marginal influence. Assuming sustainable transportation as one of the tenets of New Urbanism, as our study has done, the relation becomes clear and significant.

Table 7

Review of indicators

\begin{tabular}{|l|l|}
\hline \multicolumn{1}{|c|}{ Indicator } & \multicolumn{1}{|c|}{ Lesson } \\
\hline Location & $\begin{array}{l}\text { The strategic position of redevelopment projects located on rail lines } \\
\text { allows to rebuild the continuity of urban fabric as well as, to create a new } \\
\text { centrality for the area in question, with attractive cultural activities and } \\
\text { services. }\end{array}$ \\
\hline Timeframe & $\begin{array}{l}\text { As the urban project timeframe are long, high flexibility and the ability to } \\
\text { adopt investments to changing conditions is required. However, the } \\
\text { realization of the investment's key infrastructure elements should be } \\
\text { maintained all along. }\end{array}$ \\
\hline $\begin{array}{l}\text { Functional } \\
\text { plan }\end{array}$ & $\begin{array}{l}\text { The functional plan can be an important support for the sustainability of } \\
\text { the project because on it ensures the quality of the urban tissue through } \\
\text { the public high-standard investments, thereby defining a new image for } \\
\text { the area. Furthermore, the distribution of uses can serve an pertinent } \\
\text { response for the strategic needs of the entire agglomeration. }\end{array}$ \\
\hline $\begin{array}{l}\text { Transporta- } \\
\text { tion mode }\end{array}$ & $\begin{array}{l}\text { The quality of the adopted spatial solutions should be coherent with } \\
\text { pedestrian-friendly strategies. }\end{array}$ \\
\hline $\begin{array}{l}\text { Scale } \\
\text { of } \\
\text { connections }\end{array}$ & $\begin{array}{l}\text { The implementation of sustainable transportation should include quick } \\
\text { and comfortable connection by various means of public transportation } \\
\text { within different urban scales: metropolises, cities, districts and the city } \\
\text { center. }\end{array}$ \\
\hline $\begin{array}{l}\text { Car parking } \\
\text { policy }\end{array}$ & $\begin{array}{l}\text { Limitation of the car park ratio for non-residents in inner city } \\
\text { redevelopment projects, in conjunction with the development of the public } \\
\text { transportation network, can become an effective tool of sustainable urban } \\
\text { policy. }\end{array}$ \\
\hline
\end{tabular}


Testing the New Urbanism Principle of Sustainable Transport in the Contemporary Redevelopment Projects. Lessons from Clichy - Batignolles in Paris and the Station Area of Lodz

\section{Conclusions}

The conclusions ought to be regarded in the context of the functional plan. The New Urbanism definition of compact development is important. Krier (2009) noted that public spaces should take up between $25 \%$ and $35 \%$ of the total area of the site. In Lodz, however, the roadways alone take up $35 \%$, and to that another $14 \%$ of other public spaces that are not roadways are to be added. This confirms the excess of public spaces in the Lodz site, while simultaneously highlighting the more correct proportions of public spaces in Clichy-Batignolles. In addition, in both cases the density of the build-up is worth mentioning. The indicators are similar - the one in Lodz is even slightly higher than the one in Paris. If the average floor area ratios in the analyzed sites (which amount to 1) are compared with the average floor area ratios in the historical districts (which amount to 2), both projects appear to be pedestrian-friendly. However, these indicators have been calculated for the entire area of the development, which includes green park areas. A closer look at the intensity indicator for the individual floor area ratio makes it clear that in Lodz it wavers between 2 and over 6 (by comparison, it reaches over 6 in the city center of London). This points to a built-up structure that is too dense, especially when we compare it to the target capacity of public transport in the area, e.g. the Lodz agglomeration rail.

Sustainable transportation is also affected by the functional ratio. The domination of one function over another is problematic. Solutions that would allow various uses to exist in one area, so as to minimize the daily commute of residents, are necessary. From this perspective, the target share of offices planned in the analyzed area in Lodz - over $43 \%$ of all functions, and the relatively large $24 \%$ service spaces (in addition to $23 \%$ of public buildings) - is alarming. When we compare the user flow, which is much lower than in Paris, it is perhaps surprising to assume that Lodz will be overflowing with users and it will be easily accessible.

Finally, the issue of managing the project needs to be addressed in such a way that the guidelines of sustainable transportation can be implemented swiftly and smoothly. The importance of governance based on cooperation between the public and private spheres in green innovations is well-known in the literature (Rossiter and Smith 2018). The presented study developed this model by adding conclusions connected with sustainable transportation projects. As described above, Paris Batignolles Aménagement could serve as an example. The unit responsible for the analysis and guidelines, including the parking policy in the site. The Paris Batignolles Aménagement also coordinates the activities with strategic public actors, including branches responsible for regional transport and private investors. This makes it possible to exercise some control over the evolution of the plots in the district, in the context of sustainable development specifications.

In that respect, a deposit of $4 \%$ of the sale price of the plot was introduced. After all, the ultimate goal is sustainable development for the entire area that will take full advantage of the proposed modality transport and its capacity. It is a solution that is worth careful consideration when thinking of other investments of this type, including the station area in Lodz.

Thanks to that, the priority mode of transport and other elements that determine user comfort will remain under better control. As it has already been shown in this research paper, the coherence of many various actions is important in the pursuit of sustainable development (Table 8). This, in turn, is ensured by treating it as one of the -- of New Urbanism. The proposed approach will guarantee a high quality of contemporary urban redevelopment projects, especially if they are combined with other guidelines of pedestrian-oriented urban patterns. 


\section{Further guidance}

Table 8

\begin{tabular}{|l|l|}
\hline \multicolumn{1}{|c|}{ Threats } & \multicolumn{1}{c|}{ Recommendation } \\
\hline $\begin{array}{l}\text { Too much space dedicated to } \\
\text { roadways }\end{array}$ & $\begin{array}{l}\text { Change the proportions of land dedicated to cars in } \\
\text { favor of land dedicated to pedestrians (Lodz). }\end{array}$ \\
\hline Too high intensity indicator & $\begin{array}{l}\text { Reduce the density of un-built zones (Lodz) and } \\
\text { invest in high quality public spaces (Lodz and Clichy- } \\
\text { Batignolles). }\end{array}$ \\
\hline $\begin{array}{l}\text { Too much area reserved for open } \\
\text { public space }\end{array}$ & $\begin{array}{l}\text { Limit inappropriately designed open spaces } \\
\text { especially spaces dedicated to cars (Lodz). }\end{array}$ \\
\hline $\begin{array}{l}\text { Insufficient proportion of } \\
\text { housing use. }\end{array}$ & $\begin{array}{l}\text { Locate more housing investments close to the } \\
\text { neighborhood (Lodz). }\end{array}$ \\
\hline $\begin{array}{l}\text { Too much weight given to } \\
\text { services functions }\end{array}$ & $\begin{array}{l}\text { Provide strategic offer for potential tenants (Lodz). } \\
\text { Advertise the area as a place well addressed to } \\
\text { potential investments and future users (Lodz and } \\
\text { Clichy-Batignolles). }\end{array}$ \\
\hline $\begin{array}{l}\text { Weak cooperation between } \\
\text { public and private stakeholders }\end{array}$ & $\begin{array}{l}\text { Definition of private and public roles in the urban } \\
\text { governance of the site (Lodz). }\end{array}$ \\
\hline
\end{tabular}

\section{References}

BOARNET M. G., CRANE R. (2001), Travel by design: The influence of urban form on travel, Oxford University Press, Oxford.

CALTHORPE P. (1993), The Next American metropolis: Ecology, community, and the American Dream, Princeton Architectural Press, New York.

CALTHORPE P. (2000), New Urbanism and the Apologists for Sprawl, Places 13 (2), 67 $-69$.

CERVERO R. (1996), Mixed land-uses and commuting: Evidence from the American Housing Survey, Transportation Research Part A: Policy and Practice 30 (5), 361-377.

CERVERO R., KOCKELMAN K. (1997), Travel demand and the 3Ds: Density, diversity, and design, Transportation Research Part D: Transport and Environment 2 (3), 199-219.

CERVERO R., RADISCH C. (1996), Travel choices in pedestrian versus automobile oriented neighborhoods, Transport Policy 3 (3), 127-141.

CERVERO R., SULLIVAN C. (2011), Green TODs: marrying transit-oriented development and green urbanism, International Journal of Sustainable Development \& World Ecology 18 (3), 210-218.

CONGRESS FOR THE NEW URBANISM (2000), Charter of the New Urbanism, Retrieved from: https://www.cnu.org.

COUDROY DE LILLE L. (2016), Introduction - Entre Est et Ouest : une européanisation urbaine, Revue Géographique de l'Est 56 (3-4), 1-15.

CRANE R., CREPEAU R. (1998), Does neighborhood design influence travel? A behavioral analysis of travel diary and GIS data, Transportation Research Part D: Transport and Environment 3 (4), 225-238.

DIERWECHTER Y., COFFEY B. (2017), The travels, triumphs and travails of new urbanism: representational geographies in US newspapers, 1990-2012, Journal of Urbanism: International Research on Placemaking and Urban Sustainability 10 (4), 385-400.

DORSEY B., MULDER A. (2013), Planning, place-making and building consensus for transit-oriented development: Ogden, Utah case study, Journal of Transport Geography 32, 6576.

ELLIS C. (2002), The New Urbanism: Critiques and Rebuttals, Journal of Urban Design 
Testing the New Urbanism Principle of Sustainable Transport in the Contemporary Redevelopment Projects. Lessons from Clichy - Batignolles in Paris and the Station Area of Lodz

7 (3), 261-291

EUROPEAN COMMISSION (2011), Roadmap to a single European transport area Towards a competitive and resource efficient transport system, White Paper COM (2011) 144 final, Retrieved from: https://ec.europa.eu.

EUROPEAN COMMUNITIES COMMISSION (1993), The future development of the common transport policy. A global approach to the construction of a Community framework for sustainable mobility, Bulletin of the European Communities S. 3/93, 1-72.

FAINSTEIN S. S. (2000), New Directions in Planning Theory, Urban Affairs Review 35 (4), 451-478

FARR D. (2008), Sustainable Urbanism: Urban Design with Nature, Wiley, Hoboken.

FAURE A. M. (1994), Some Methodological Problems in Comparative Politics, Journal of Theoretical Politics 6 (3), 307-322.

FRANK L. D., PIVO G. (1994), Impacts of mixed use and density on utilization of three modes of travel: single-occupant vehicle, transit, and walking, Transportation Research Record 1466, 44-52.

GREENWALD M. J., BOARNET M. G. (2002), Built environment as determinant of walking behavior: Analyzing nonwork pedestrian travel in Portland, Oregon, Transportation Research Record 1780 (1), 33-41.

INTERNATIONAL ENERGY AGENCY (2009), Transport, energy and $\mathrm{CO}_{2}$ : Moving towards sustainability, International Energy Agency, Paris.

JOH K., BOARNET M. G., NGUYEN M. T., FULTON W., SIEMBAB W., WEAVER S. (2008), Accessibility, travel behavior, and new urbanism: Case study of mixed-use centers and auto-oriented corridors in the South Bay Region of Los Angeles, California, Transportation Research Record 2082 (1), 81-89.

KRIER L. (2009), The Architecture of Community, Island Press, Washington, D.C.

KUNSTLER J. H. (1993), The Geography of Nowhere: The Rise and Decline of America's Man-Made Landscape, Simon \& Schuster, New York.

LANGDON P. (2017), Within Walking Distance: Creating Livable Communities for All, Island Press, Washington, D.C.

LIN J. J., GAU C. C. (2006), A TOD planning model to review the regulation of allowable development densities around subway stations, Land Use Policy 23 (3), 353-360.

MA X., CHEN X., LI X., DING C., WANG Y. (2018), Sustainable station-level planning: An integrated transport and land use design model for transit-oriented development, Journal of Cleaner Production 170, 1052-1063.

MARSHALL W. E. (2015), Understanding the impacts of integrating New Urbanist neighborhood and street design ideals with conventional traffic engineering standards: the case of Stapleton, Journal of Urbanism: International Research on Placemaking and Urban Sustainability 8 (2), 148-172.

MOUDON A. V., HESS P. M., SNYDER M. C., STANILOV K. (1997), Effects of site design on pedestrian travel in mixed-use, medium-density environments, Transportation Research Record 1578 (1), 48-55.

NADIN V. (2012), International Comparative Planning Methodology: Introduction to the Theme Issue, Planning Practice \& Research 27 (1), 1-5.

PAPA E., BERTOLINI L. (2015), Accessibility and Transit-Oriented Development in European metropolitan areas, Journal of Transport Geography 47, 70-83.

QVISTRÖM M., BENGTSSON J. (2015), What Kind of Transit-Oriented Development?

Using Planning History to Differentiate a Model for Sustainable Development, European Planning Studies 23 (12), 2516-2534.

RODRÍGUEZ D. A., KHATTAK A. J., EVENSON K. R. (2007), Can New Urbanism Encourage Physical Activity? Comparing a New Urbanist Neighborhood with Conventional Suburbs, Journal of the American Planning Association 72 (1), 43-54.

ROSSITER W., SMITH D. J. (2018), Green Innovation and the Development of Sustainable Communities: The case of Blueprint Regeneration's Trent Basin Development, The International Journal of Entrepreneurship and Innovation 19 (1), 21-32. 
SAELENS B. E., SALLIS J. F., FRANK L. D. (2003), Environmental correlates of Walking and Cycling: Findings from the Transportation, Urban Design, and Planning Literatures, Annals of Behavioral Medicine 25 (2), 80-91.

SCHUYLER D. (1997), Review: The new urbanism and the modern metropolis, Urban History 24 (3), 344-358.

SKALSKI K. (2009), Rewitalizacja we Francji - zarządzanie przekształceniami obszarów kryzysowych $w$ miastach (Urban regeration in France, management of the transformation of crisis areas in cities), Rewitalizacja Miast Polskich, Cracow.

SPECK J. (2012), Walkable City: How Downtown Can Save America, One Step at a Time, Farrar, Straus and Giroux, New York.

TALEN E. (2008), Design for Diversity: exploring socially mixed neighbourhoods, Architectural Press, Oxford.

TALEN E. (ed.) (2013), Charter of New Urbanism (2nd ed.), McGraw-Hill, New York.

TELLIS W. M. (1997), Introduction to case study, The Qualitative Report 3 (2), 1-14.

RESOLUTION NO. III/40/14 OF THE CITY COUNCIL IN LODZ (2014), Uchwała Nr. III/40/14 Rady Miejskiej w Łodzi w sprawie uchwalenia miejscowego planu zagospodarowania przestrzennego dla części obszaru miasta Łodzi położonej w rejonie ulic: Prezydenta Gabriela Narutowicza, dr. Stefana Kopcińskiego i Juliana Tuwima na wschód od planowanego przedłużenia ulicy Uniwersyteckiej (Resolution No. III/40/14 of the City Council in Lodz on the adoption of a local zoning plan for a part of the city of Lodz located in the vicinity of streets: Prezydenta Gabriela Narutowicza, dr. Stefan Kopciński and Julian Tuwim east of the planned extension of Uniwersytecka street), Lodz City Council, Lodz.

RESOLUTION NO. III/41/14 OF THE CITY COUNCIL IN LODZ (2014), Uchwała Nr. III/41/14 Rady Miejskiej w Łodzi w sprawie uchwalenia miejscowego planu zagospodarowania przestrzennego dla części obszaru miasta Łodzi położonej w rejonie ulic: Prezydenta Gabriela Narutowicza, Williama Lindleya, Wodnej, Julian a Tuwima i Henryka Sienkiewicza Lodz (Resolution No. III/41/14 of the City Council in Lodz on the adoption of a local zoning plan for a part of the city of Lodz located in the vicinity of streets: Prezydenta Gabriela Narutowicza, William Lindleya, Wodna, Julian a Tuwima and Henryk Sienkiewicz Lodz), Lodz City Council, Lodz.

WBCSD (2004), Mobility 2030: Meeting the challenges to sustainability, World Business Council for Sustainable Development, Retrieved from: https://www.oecd.org.

WOHL S. (2017), From form to process: Re-conceptualizing Lynch in light of complexity theory, Urban Design International 22 (4), 303-317.

WORLD BANK (1996), Sustainable transport: priorities for policy reform, Development in practice, The World Bank, Washington, D.C.

Initial submission: 12.09 .2018

Revised submission: 22.12.2018

Final acceptance: 07.05.2019

Correspondence: Faculty of Civil Engineering, Architecture and Environmental Engineering, Institute of Architecture and Urban Planning, Lodz University of Technology, Stefana Żeromskiego 116, 90-924 Łódź, Poland.

Email: monika.cysek@p.lodz.pl 


\title{
THE ADVANTAGES AND ANALYSIS OF THE LOCATION OF BRANCHLESS BANKING IN URBAN AND RURAL AREAS IN YOGYAKARTA SPECIAL REGION, INDONESIA
}

\author{
Rini RACHMAWATI, Nur Mohammad FARDA, R. RIJANTA, Bowo SETIYONO \\ Universitas Gadjah Mada, Yogyakarta, Indonesia
}

\begin{abstract}
Branchless banking is a banking service based on ICT, one of which is an agent This service can be found in both urban and rural areas. This research aims at identifying the existence and advantages of agents-based branchless banking. The locations of branchless banking agents was also analyzed to explore the spatial pattern. This research applies a quantitative method. Agents and customers are selected by undergoing a survey. The data are obtained by structurally interviewing agents on the kinds of services they provide and the benefits of services for customers. Meanwhile, an accidental sampling technique is used to select customers. Besides, spatial analysis is applied using kernel density analysis and accessibility analysis. The result of the research shows that the advantages of branchless banking through agent alter the perception of spatial benefits to access banking services. The space for banking services is in the same place for other purposes such as business units and home. In urban areas, the making use of agents is mainly based on the factors of being closely located and easy to access. Meanwhile, in suburban and rural areas, conveniences are of primary consideration to make use of agents. Concerning the geographical field, location plays an essential role in the substantial changes related to the spatial functions of economic services, mainly banking services, which are not always located in downtown areas. On the contrary, it is possible to locate economic services in rural areas, with the help of ICT-based services. The result of the analysis shows that banks do not optimally consider location, range and service area for branchless banking represented by agents.
\end{abstract}

Key Words: location, urban, suburban, rural, branchless banking, agents.

\section{Introduction}

In the past, for serving customers, banking services still applied conventional ways. One example is that they had to head for the location of a bank for every transaction they made. Therefore, to get a banking service, customers had to do physical motion, meaning that means of transportation, transportation cost, and time had to be spent. The farther the location of a bank was, the higher the cost and the longer the time would be to reach the bank.

Today, Information and Communication Technology (ICT) has experienced rapid improvement. Information and Communication Technology is defined as a means of technology and its applications in an electronic process to transmit information for various uses (Cohen et al. 2002). Moreover, the application of ICT has dramatically improved and it led to penetration in various occupations and lifestyles (Cohen et al. 2002); one of them is related to bank sector. The use of ICT is also giving some impact on location decentralization, especially for settlement, firm, and office (Rachmawati 2013, Rachmawati et al. 2015).

The benefit of ICT, such as telephone, handphone, internet, and ATM (automatic teller machine), is a great help for people to meet their need for banking services (Rachmawati 2009). There is no need for them to go to the bank for doing transactions since they can go to the nearest ATM from either home or workplace (Rachmawati and Rijanta 2012).

Information and communication technology has become a global trend and it influenced the 
world of business like service by using internet (Bhat et al. 2003). Revolution in technology has changed human life related to time and place, mainly for the application of ICT, such as ebanking and electronic cash transfer (Stilwell 1992), and also the work pattern that is shown by the change of work hour, location and manner (Rachmawati et al. 2010). E-banking services enable people to receive banking services without doing any movement and giving some impact on less movement of people, time and cost as well (Rachmawati and Rijanta 2012). This service is also used by the small medium enterprises sector that makes trade transaction easier (Rachmawati et al. 2018).

E-banking and also ATM are included in branchless banking services. Muthinja and Chipeta (2018) mention that mobile banking is also involved in branchless banking innovations, other than that, internet banking and ATM and agency banking as well. E-banking is not easy enough to be used by certain people who do not have access to these services, especially for people in the suburbs and rural areas. A service is needed that makes it easy for people to access, and one of them is branchless banking system through an agent. In the last two decades, a lot of banking innovation has taken place to improve the financial performance of commercial banks (Dzombo et al. 2017). Branchless banking which involves the use of agency banking and electronic banking channels in the distribution of banking products and services is one such innovation (Dzombo et al. 2017).

The application of branchless banking is not only found in developed, but also in developing countries. Brazil, for example, has 150000 service points, meaning five times the number of banks and contributing to $80 \%$ of the social benefits from the government for more than 40 million people with limited or no access at all to banking services (Jayo et al. 2012). The development of branchless banking will result in potential benefits to stakeholders in many different forms, such as a program that is more effective for social benefits, an increasing number of payment for electricity and water bills, and a better return for bank loan (Ivatury 2006, Diniz et al. 2009, Jayo et al. 2012). Branchless banking brings much-needed financial services to the unbanked in the developing world (Reaves et al. 2015). Ansong et al. (2015), for instance, argue that the disproportionate growth of physical/traditional branch banking leads to disparities in the spatial distribution of bank branches. They conclude that branch banking needs modernization through the development of electronic infrastructure such as mobile phone banking, offering more attractive, efficient, and cost-effective operations. Branchless banking will help Indonesia to decrease its number of unbanked people (Shabirah and Aldianto 2014). Leveraging ubiquitous cellular networks, these services are now being deployed as smartphone apps through providing an electronic payment infrastructure (Reaves et al. 2015).

Several banks in Indonesia have introduced branchless banking services, mainly to make it accessible in providing services for the people who find difficulty getting physical banking services. Such people are those, especially, who live in rural areas. Therefore, the existence of agents is expected to meet their need. The banking industry is required to improve its financial services for the benefits of people. According to Otoritas Jasa Keuangan (2014), the low rate of accessing financial services in Indonesia is caused by, among others, the large number of areas with limited banking services, the low income of the majority of people, and the low financial literacy of people on products and financial services. The branchless banking program is implemented to enlarge access of people to banking services and, at the same time, to be one of the front liners in improving the financial literacy with the helping role of agents (marketing roles). The success of this program can also be determined by the stipulations of location and access, the ease of use, or the perceived benefits.

This research aims at identifying the existence and advantages of agents-based branchless banking. The locations of branchless banking agents were also analyzed to explore the spatial pattern. This research is implemented by comparing branchless banking services through agents in urban, suburban, and rural areas. Furthermore, how the implementation of 
branchless banking in those three areas is and what the characteristics of location and physical condition of areas are will also be of concern for this research. The information from the research result can give a new perspective on the bank, especially as an input to develop branchless banking in urban and rural areas as well. Research on branchless banking is very important in order to provide information that will help policymakers and practitioners to focus their continued efforts on creating an enabling environment for branchless banking (Dermish et al. 2012).

\section{Methodology}

This research was carried out in urban, suburban and rural areas of Yogyakarta Special Region. The study area has been served by branchless banking system through an agent from the Bank. The obtained information is primary data by doing field observations and structured interviews. The agents were structurally interviewed on the kinds of services they provide and the benefits to the customers. To select the agents, a survey was done until the location of agents was found. In addition, a structured interview with the customers was also done to obtain data on the benefits of branchless banking. The accidental sampling technique was used to choose the respondents as customers of branchless banking. Accidental sampling is a type of nonprobability sample. Sampling was carried out by selecting the cases at hand until the desired number of people/items was reached (Wilson 2014). Data collecting from the respondents stopped when the information was already saturated. Meanwhile, spatial analysis was applied by using GIS to find out the distribution of agents and customers, and it was associated with the physical condition of areas and accessibility, namely through kernel density analysis (Silverman 1986) and the accessibility analysis workflow (Fig. 1).

The agents and customers of branchless banking coordinate locations used as input for spatial density analysis. The density analyses calculated an appropriate search distance for determining the neighborhood size and to classify the output as an equal interval with five classes, and to provide the output densities in square kilometers (Silverman 1986). The other geographic perspective was the accessibility analysis using the weighting overlay (Road + Settlement + Slope). This analysis developed from combining the Euclidean distance of road and settlement (the closer it is, the value is higher), and slope (the more flat it is, the higher are the values). Accessibility Map delivers from the addition (+) of Euclidean Distance to Road, Euclidean Distance to Settlement, and Slope. The zero value (0) indicates low accessibility, and the value of three indicates high accessibility.

\section{Results and Discussion}

\section{Overview of branchless banking}

ICT has benefited to improving, among others, comfort, ease in mobility, and efficiency in cost and energy (Nam and Pardo 2011). Therefore, the development in information and communication technology is required to facilitate all activities carried out by the government, companies, and citizens.

In developing countries, innovation has helped government to reduce poverty, to push development in economic sectors, and to increase financial access for poor and low-income families (Karlan and Morduch 2010). For example, the application of ICT in banks (e.g. branchless banking) is not only able to increase financial access for society, but also, at the same time, it offers other financial services for them. These are, for example, cash flow management, saving, and deposit, money transfer, bill payment, or other benefits related to financial aids from the government. Branchless banking is now regarded as a practical approach to enlarge financial services in remote regions where there are hardly any bank branches (Mas 2009). The most important aspect of branchless banking is the availability of ICT to enable banks and their clients to be connected with the help of agents that have different 


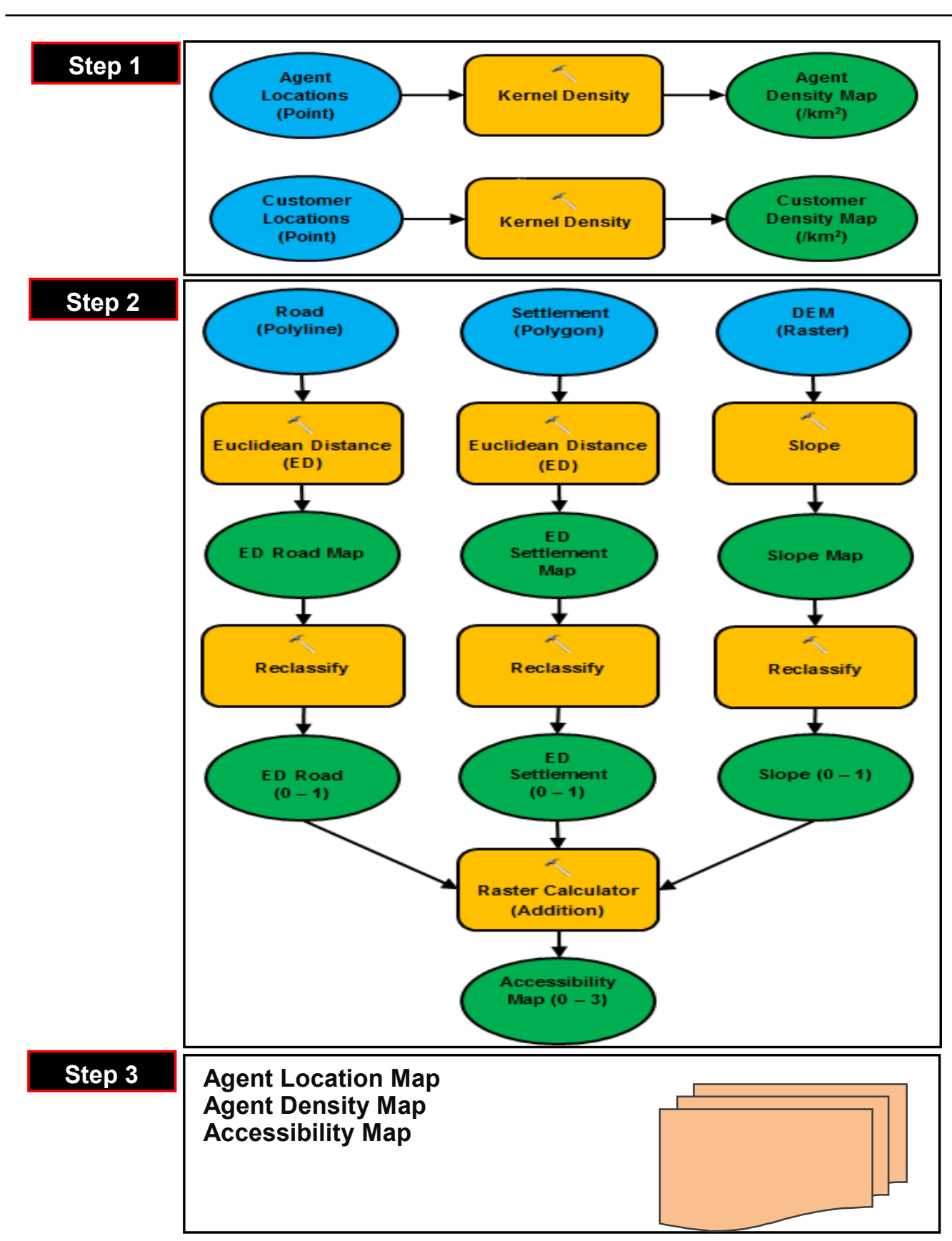

Fig. 1 - Agent and Customer Branchless Banking Kernel Density Analysis and Accessibility Analysis Workflow 
The Advantages and Analysis of the Location of Branchless Baking in Urban and Rural Areas in Yogyakarta Special Region, Indonesia

backgrounds and come from different places (Jayo et al. 2012).

In the banking sector, the development of ICT has changed the traditional brick-and-mortar banking or single channel model into the more ICT based or multi-channels model, for instance, ATM and internet banking (King 2018). Physical bank branching can be very costly especially when the branch's catchment area lacks the substantial depository base and potential borrowers. Such provision not only supports the promoting of financial inclusion in an economy but it also enables banks to provide their services at more affordable costs that eventually lower the prices to the customers. ICT, however, leads to many bank closures and consolidation (The Economist 2002).

Another strand of literature argues that the ICT based banking, hence branchless banking, will have disadvantages to accumulate valuable know-how about market and business opportunities in the targeted area because they are not able to interact directly or personally to the potential borrowers/depositors. In other words, banks need to be geographically closer to their market in order to collect and to extract important soft information in addition to hard information, especially from the borrowers (Agarwal and Hauswald 2010). Furthermore, operating branch office closer to their customers would build stronger lending relationships and credit quality (Udell 2009).

The presence of agents in the branchless banking might be regarded from the spatial attractiveness that they offer more convenience to the respective markets. Such geography proximity will attract customers because bank products and services now became spatially available in a short distance. Hinson et al. (2009), for example, find that proximity is one of the most important determinants of bank choice. Branchless banking has become an important innovation offering various benefits to their customers and it eventually improved the banks' financial performance (Muthinja and Chipeta 2018).

There are several notions of branchless banking, as stated below:

"Branchless banking is about building a general payments infrastructure that allows people (...) to deposit and withdraw funds and make electronic payments (...), thus eliminating the need for bank branches (...)" (Dermish et al. 2012: 82).

"Branchless banking is a modern mechanism to facilitate financial services in developing regions. There is a considerable growth taken place in branchless banking services in India, despite this, branches are unlikely to die, despite ATMs, laptops and smartphones becoming primary platforms for daily banking" (Anand and Sreenivas 2013: 1).

"Branchless banking is a distribution network that delivers financial services outside of conventional bank branches through technology and alternative networks with more effective and efficient costs as well as offering security and convenience" (Otoritas Jasa Keuangan 2014: 74).

In general, branchless banking services are applied to increase the financial access of the society and to support the efforts for the even distribution and development of bank services. In this case, the role of agents is as an operator of branchless banking program. Agents serve as the side cooperating with an operating bank that is in charge of providing bank services. The branchless banking program is expected to be able to reach those who are not able to be served by a bank office network in a physical way (Otoritas Jasa Keuangan 2014). Instead, it makes use of the means of information technology in the forms cellular phone, Electronic Data Capture (EDC), and internet banking. As a result, the application of technology can reduce costs and the time that people spend in doing their financial transaction. 


\section{Branchless banking services provision}

The branchless banking program is a type of financial services without offices by enlarging the bank service coverage without physically opening a new branch. In Indonesia, it is known as Laku Pandai (Otoritas Jasa Keuangan 2017). Laku Pandai means: Officeless Financial Services for Inclusive Finance, a program of the Financial Services Authority Program for the provision of banking services or other financial services through cooperation with other parties (i.e. bank agents), and supported by the use of information technology facilities (Otoritas Jasa Keuangan 2017). It is implemented by making use of technological media as well as help from agents, such as shops, post offices and individuals (Otoritas Jasa Keuangan 2017).

Based on the POJK Number 19/POJK/03/2014 on financial services without an office in the framework of inclusive finance, this regulation enables a bank to have an authority to cooperate with agents serving as the extension of the bank in providing services to customers, ranging from an account opening to an account closing (Otoritas Jasa Keuangan 2014). Branchless banking service that is regulated on POJK Number 19/POJK/03/2014 is a saving product with the characteristic of Basic Saving Account (BSA) and credit/payment to micro customers, and other bank services as well:

"Branchless banking in Indonesia is led-by bank. There are two aspects of suitable model of branchless banking in Indonesia, which are from technology and regulation. Technology: Technology in branchless banking is using mobile mini ATM (...). Regulations: there are two regulations in branchless banking (...), which are through retail agent, such as cooperation, shops, and village hall. The second method is branchless banking by bank officer who comes to customer place" (Shabirah and Aldianto 2014: 644).

Based on the Regulation of Otoritas Jasa Keuangan (2014) on Financial Services Outside Office, article 4, the kinds of service products that agents can serve to customers are saving, loan for micro customers, micro insurance, and other services that Otoritas Jasa Keuangan approves. Saving service at an agent is just like the one that a bank office provides, for example, saving, withdrawal, and transfer/remittance. Loan service or financing for micro customers constitutes the one in the forms of giving loan and/or loan return. Microinsurance service is a kind of insurance product intended for low-income people. Meanwhile, other services include the distribution of financial aids and other bank services. The network to facilitate branchless banking needs to meet the following essential elements (Mas 2009): (1) A retail shop that is easy to access for customers, (2) Electronic infrastructure that makes the fast transaction possible, and (3) Account platform in the bank to retain and accomplish the transaction record.

Based on the Otoritas Jasa Keuangan's data in 2017, there are 22 banks that provide branchless banking services in Indonesia. Meanwhile, the results of the survey in the areas where this research was carried out showed that six banks provide branchless banking services. They are: BTPN, BTPN Syariah, BRI, BRI Syariah, BNI, and Mandiri.

\section{The existence and the use of branchless banking}

The results of the survey show that there is a difference in terms of the number of agents and customers in urban and rural areas. In the city of Yogyakarta, there were 58 agents found, with 30 agents in the suburbs of Yogyakarta, and 67 agents in the Regency of Kulon Progo. Compared with the city of Yogyakarta and the suburbs of the Regency of Sleman, the Regency of Kulon Progo, where most of its areas are rural areas that are located relatively far from the business center and bank offices, has the most number of agents. This is confirmed by a statement of Franksiska et al. (2017) who mention that branchless banking technology was easy to learn and easy to operate, even for the rural community. Meanwhile, the number of 
customers was obtained based on the finding results when doing field surveys by using accidental sampling. In the city of Yogyakarta, 36 customers were found, 30 customers in the suburbs of the city of Yogyakarta, and 41 customers in the Regency of Kulon Progo.

The increasing number of branchless banking agents is the result of the offer made by banks to be an agent in each area. Besides an offer made by banks, the government program of distributing aids to a certain group of families is another factor that makes the number of agents increase, especially in the city of Yogyakarta. The average length of period to be an agent of branchless banking is one year. However, several agents have been active for three years as found in the Regencies of Kulon Progo and Sleman. Fig. 2 shows the reasons for becoming an agent. They are, among others, receiving an offer from bank, proposing to be an agent, and being appointed by the bank. Meanwhile, Fig. 3 shows data on the length of period to be an agent, which is between one and three years.

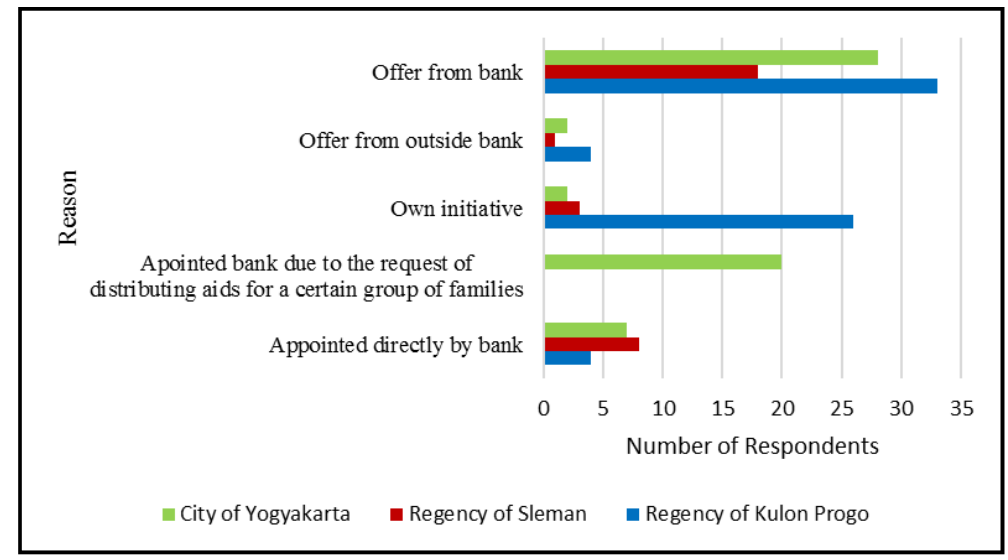

Fig. 2 - Reasons for becoming an agent

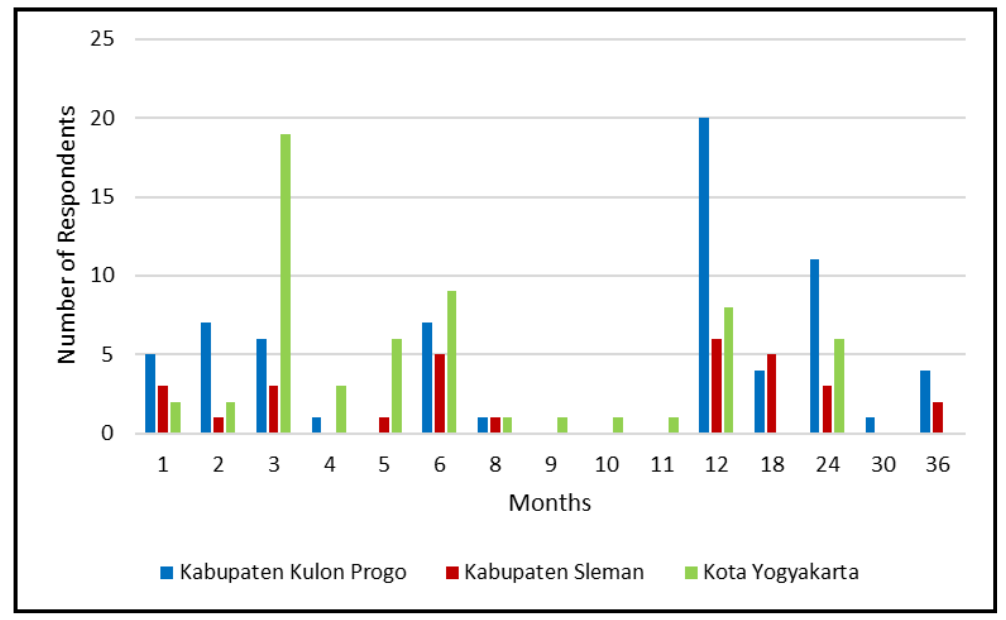

Fig. 3 - Length of period to be an agent 
The frequency of benefiting of an agent shows a difference between rural and suburban areas. In rural areas of Kulon Progo, 30 transactions are made daily. Meanwhile, ten transactions are daily made in the city of Yogyakarta and five transactions in the suburban areas belonging to the Regency of Sleman (Fig. 4). The average agent, irrespective of the difference, reveals that at least one transaction is made daily in each area. The most dominant transaction in the city of Yogyakarta is cash saving and aid disbursement for certain group of families. Meanwhile, in the suburban areas, cash saving and transfer are dominant transactions and, in rural areas, cash saving and payment for electricity bill are very dominant (Fig. 5). The success of branchless banking in Kenya does show that there is a real customer demand for convenient money transfers and payments and, to a lesser extent, savings (Dermish et al. 2012). Concerning the benefiting branchless banking services, the average customer has made use of them for one year, with the longest of three years (Fig. 6).

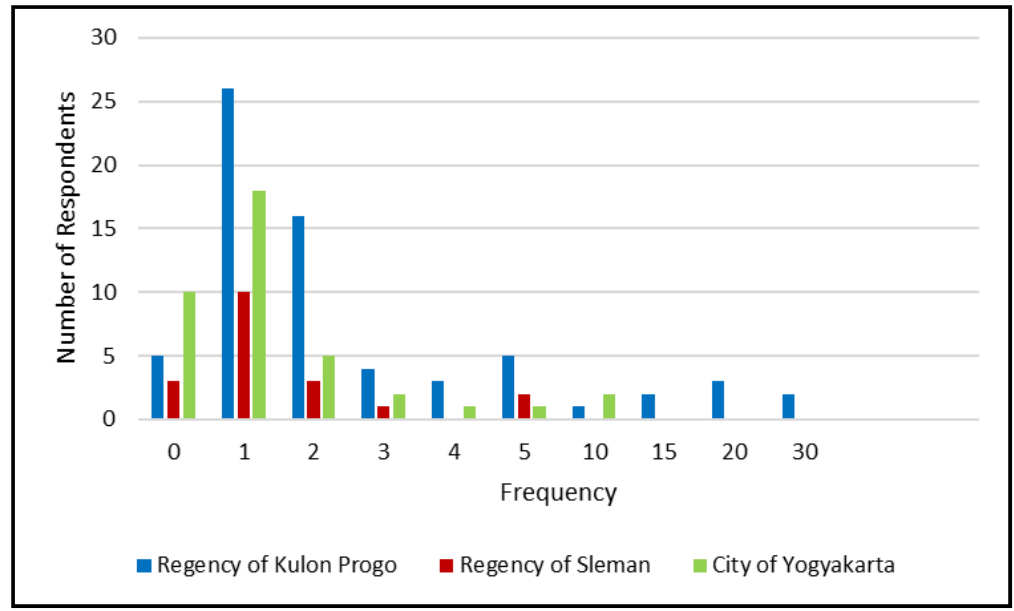

Fig. 4 - Frequency of daily transactions according to agents

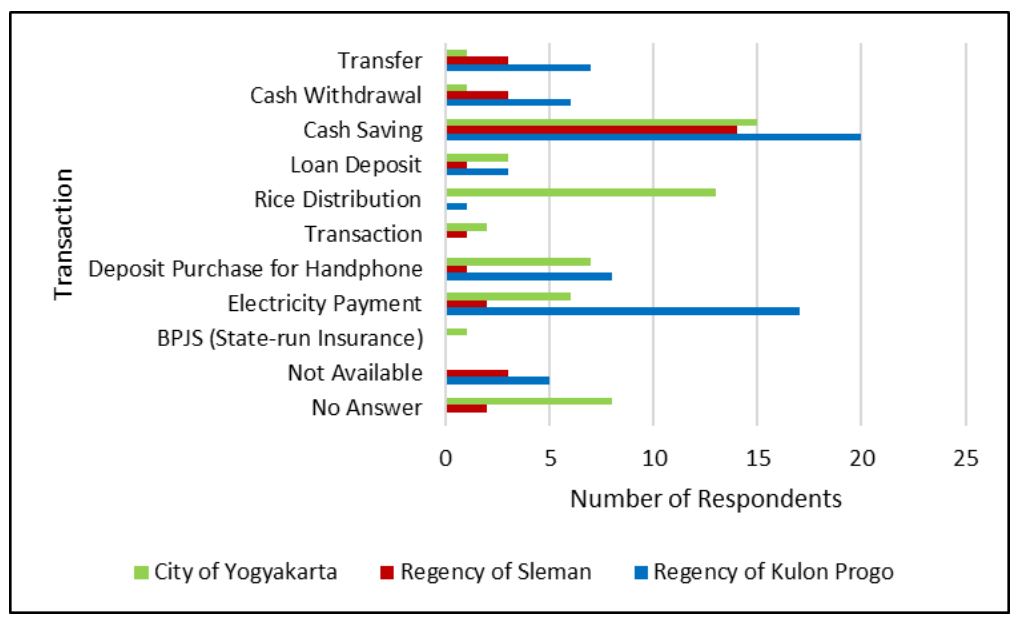

Fig. 5 - Kind of most frequently made transactions according to agents 


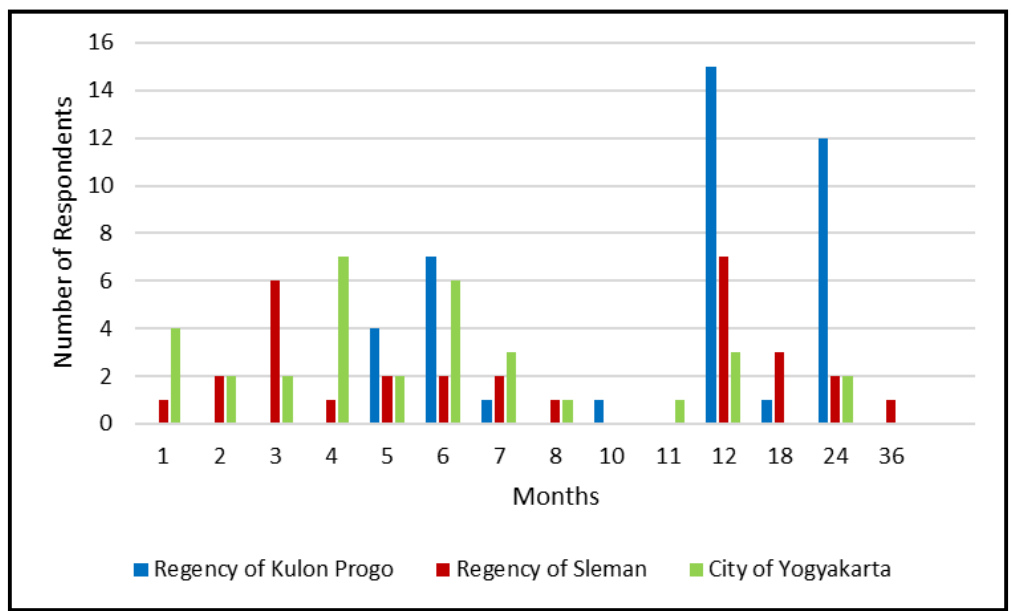

Fig. 6 - Length of period to be a branchless banking customer

The result of the interview with the customers shows that they make transactions once a week. Several customers make a transaction only when they feel the need, so that their intensity is not measurable. In urban areas, several customers go to see the agent at the time when there is an aid distribution. Meanwhile, cash saving is the most dominant transaction that the customers make in the three areas of research. Besides this, deposit purchase for handphone and electricity and aid distribution from the government are the second dominant transactions after cash saving.

\section{The Benefits of branchless banking in urban, suburban, and rural areas}

The results of the research show that the advantages of becoming an agent are that he can get extra income, increase his business reputation, and receive some bonus and facilities. The agent's income rises because of the profit he makes from every transaction made by the customers. Besides this, customers also tend to buy something in the agent's shop because most agents also run other businesses. Bonus and facilities are also given by the bank to the agent. Several agents in the suburban areas reveal that an advantage they can make by becoming an agent is that they can help people in their surrounding areas.

The main benefit that most customers feel because of the presence of branchless banking services is that they can save their time since the agent is closely located to their home. The percentage of respondents making such a statement is as follows: $34 \%$ in the city of Yogyakarta, $34 \%$ in the suburban of Yogyakarta, and $24 \%$ in the rural areas of Kulon Progo Regency. Meanwhile, the second benefit that most customers feel is that they can save their travel costs in those three areas, as follow consecutively: $21 \%, 26 \%$, and $21 \%$. The other benefit that most customers feel is eventually that the service can be given at any time, even on holidays, not being limited by office hours. Related to the advantages of time flexibility in utilizing branchless banking, it can be said that this service improves the services of banks that are limited by time. The research results from Shabirah and Aldianto (2014) about the respondents' perception towards banking evidence that the bank is considered secure, but the problem is that the bank does not have flexible opening hours. Meanwhile, branchless banking services through this agent are seen as providing flexible services in terms of time. Customers are even able to make transactions like cash saving even with a small amount of money. Besides, a sense of cohesiveness and convenience are also felt by the customers (Fig. 7, 8, 9). 


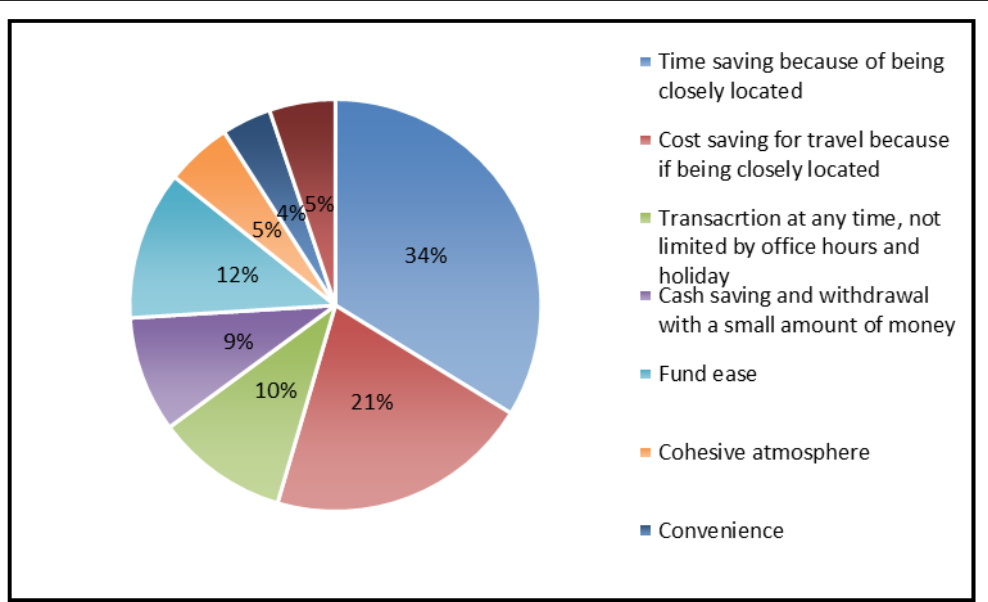

Fig. 7 - Benefits mostly felt by the customers in the city of Yogyakarta

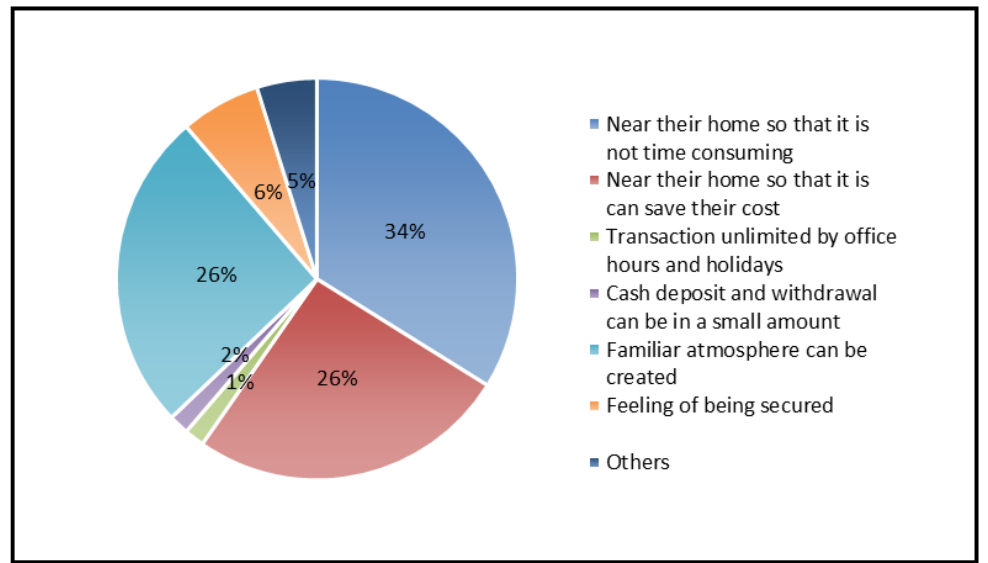

Fig. 8 - Benefits mostly felt by the customers in the suburban areas of Yogyakarta

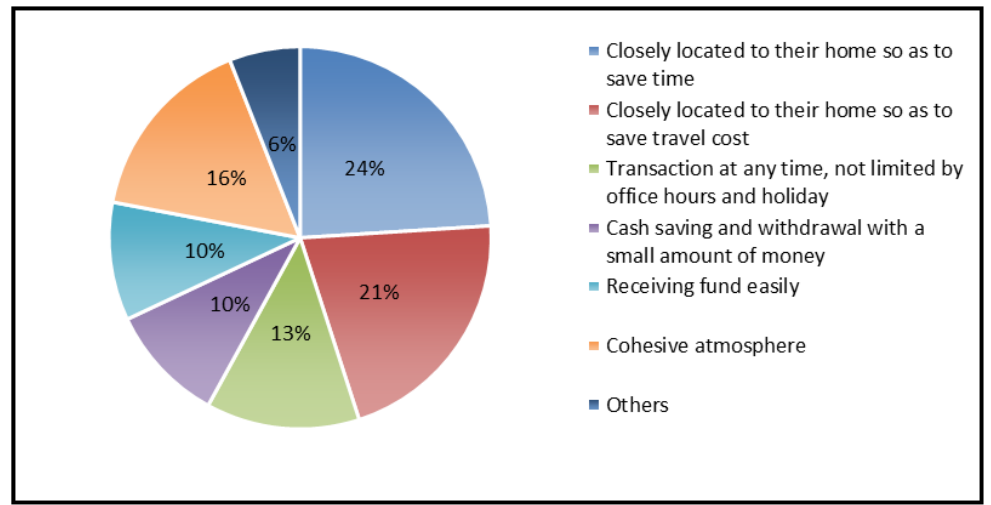

Fig. 9 - Benefits mostly felt by the customers in the rural areas of Kulon Progo Regency 
Regarding the benefits of using branchless banking, a part of the respondents mention that they get a cohesive atmosphere and the feeling of being secure and convenient. Reaves et al. (2015) also mention about the security reason in using branchless banking. By enabling access to a cashless payment infrastructure, these systems allow the residents of such countries to reap the benefits afforded to modern economies and to decrease the physical security risks associated with cash transactions (Reaves et al. 2015). Although people in rural areas still have some anxieties, such as scams, the community's intention to adopt a branchless banking technology is quite high (Franksiska et al. 2017). In Pakistan, consumers perceive risks such as the misuse of financial information which hinder them from adopting mobile banking services. Therefore, the mobile banking service providers need to plan a higher security in providing services in order to achieve a higher consumer acceptance (Kazi and Mannan 2013). Regarding the branchless banking services, namely the agents present more trust factors because most of service users recognize them (in the case of rural areas, agents are their neighbors). Agents usually work in grocery stores, handphone credit counters, photocopies or another stores. Besides that, it is also because the transactions they do are mostly small transactions, such as electricity payments, handphone credit purchases, and loan installments so that the perception of risk does not appear as a problem in using branchless banking-agents.

Otherwise, Abbas et al. (2015) mention about how to create a good service both from policymakers in the bank sector and from the relevant parties as well:

"It can be suggested from our findings that the most important factors of service quality are service reliability, responsiveness and assurance. Policy makers in branchless banking should pay more heed to increase the reliability of service. (...) Factors such as responsiveness and assurance can be addressed by SBP regulations, banks and the third parties that implement and execute the branchless banking. (...) In addition, there is a need to grow digital literacy among the non-users of branchless banking which will augment the number of users in future" (Abbas et al. 2015: 1490).

To develop branchless banking in Indonesia, we should consider the values of the society, its religion, and beliefs, the community willingness, the local wisdom, and the tradition and culture of a wide area as well (Santoso and Ahmad 2016). In addition, this research adds another factor which is necessary to consider, i.e. location and accessibility.

\section{The location analysis of branchless banking services}

Location is the main factor for customers to make use of branchless banking services. Being closely located to the agent of branchless banking services from their home is the biggest benefit that customers get. In every sub-district of the city of Yogyakarta, an agent of branchless banking services is found. The agents are mostly found quite far from the business center and downtown area, like the ones found in the sub-districts of Kotagede and Umbulharjo (Southern part of Yogyakarta city). Both sub-districts are also densely populated. The existence of agents in the city of Yogyakarta shows that they are found in the settlement areas located on the sides of collector roads and artery roads connecting every sub-district and the surrounding regencies of the city of Yogyakarta.

The presence of agents in the rural areas of Kulon Progo Regency has different characteristics in their distribution if compared with that in the urban and suburban areas. The agents in the Regency of Kulon Progo are mostly found in the settlement areas of rural areas, particularly the ones located far from the city center. The density of the agent's locations is also found on the sides of artery roads, though not as many as those on collector roads. There are several agents found on the roadsides of villages, though the number of them is smaller than that on the sides of arterial roads. In the Regency of Kulon Progo, the agents are mostly found in the 
sub-districts of Panjatan, in the Sothern part of Kulon Progo Regency, and Kalibawang, in the Northern part of Kulon Progo Regency (Fig. 10). The sub-district of Kalibawang is located the farthest from the city center. This proves that the presence of branchless banking services through agents is indeed needed to enlarge the coverage of banking services and the people living in rural areas are able to make use of them.

Meanwhile, in the suburban areas belonging to the Regency of Sleman, the biggest number of agents is found in the sub-district of Depok. This area has rapidly developed because it is located in the suburb of Yogyakarta and there are many university and college campuses and newly-developed residences. The agents are also found on the sides of collector roads in the suburb, for example, the ones found along Godean Street, a collector road in the sub-district of Godean. Running a business on the side of a collector road has benefitted the business owner to improve his business by becoming an agent of branchless banking. It is easy for the customers to reach an agent while being located between the city of Yogyakarta and the Regency of Sleman.

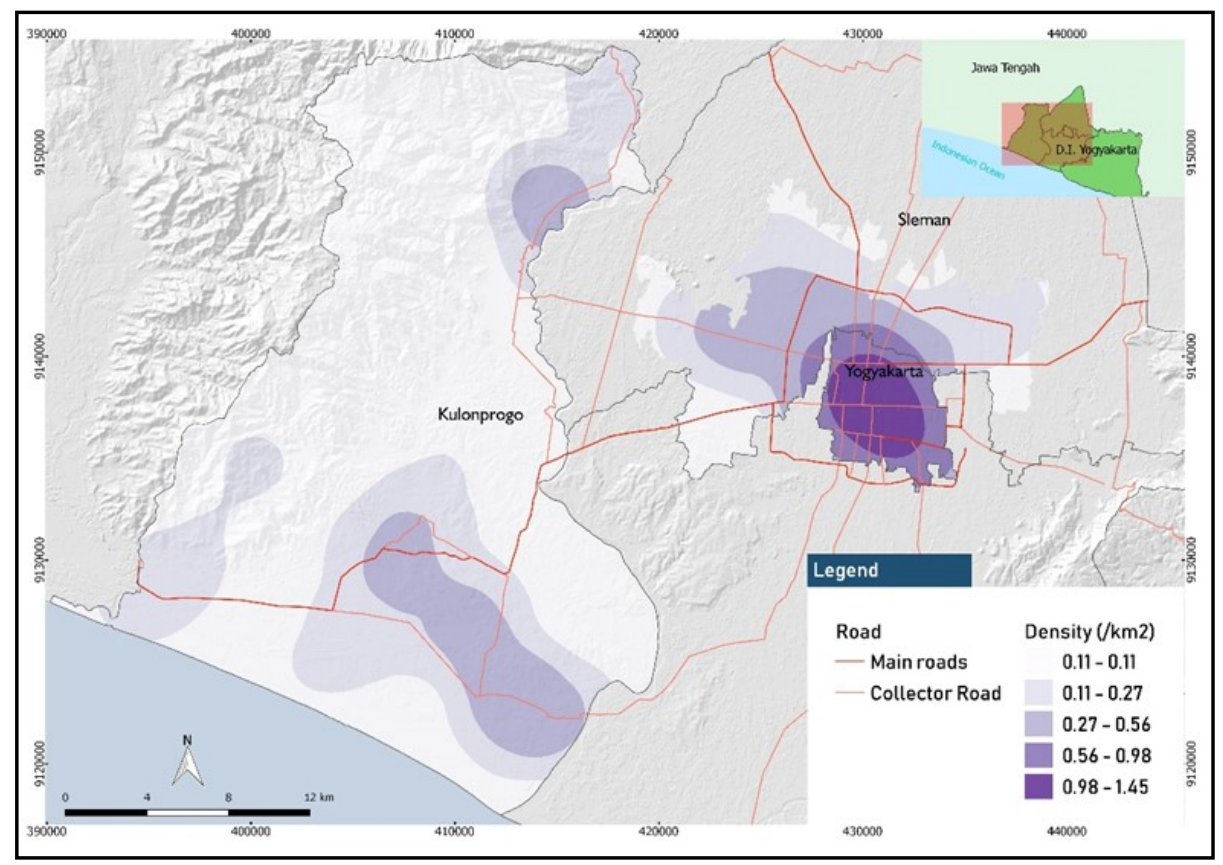

Fig. 10 - Branchless Banking-Agent Density Analysis Map in urban, suburban and rural areas

Fig. 11 shows branchless banking-agent customer density analysis map in urban, suburban and rural areas. The location mapping of customers is based on data collection through accidental sampling. Therefore, the distribution map of customers is not based on the real number of customers in each place of research. This is because the number of customers is only based on the number of service users found at the time of the field survey.

On the density map of the Regency of Kulon Progo, the number of customers is mostly found in the southern part of the regency. Meanwhile, in the suburban areas of Yogyakarta city, the 


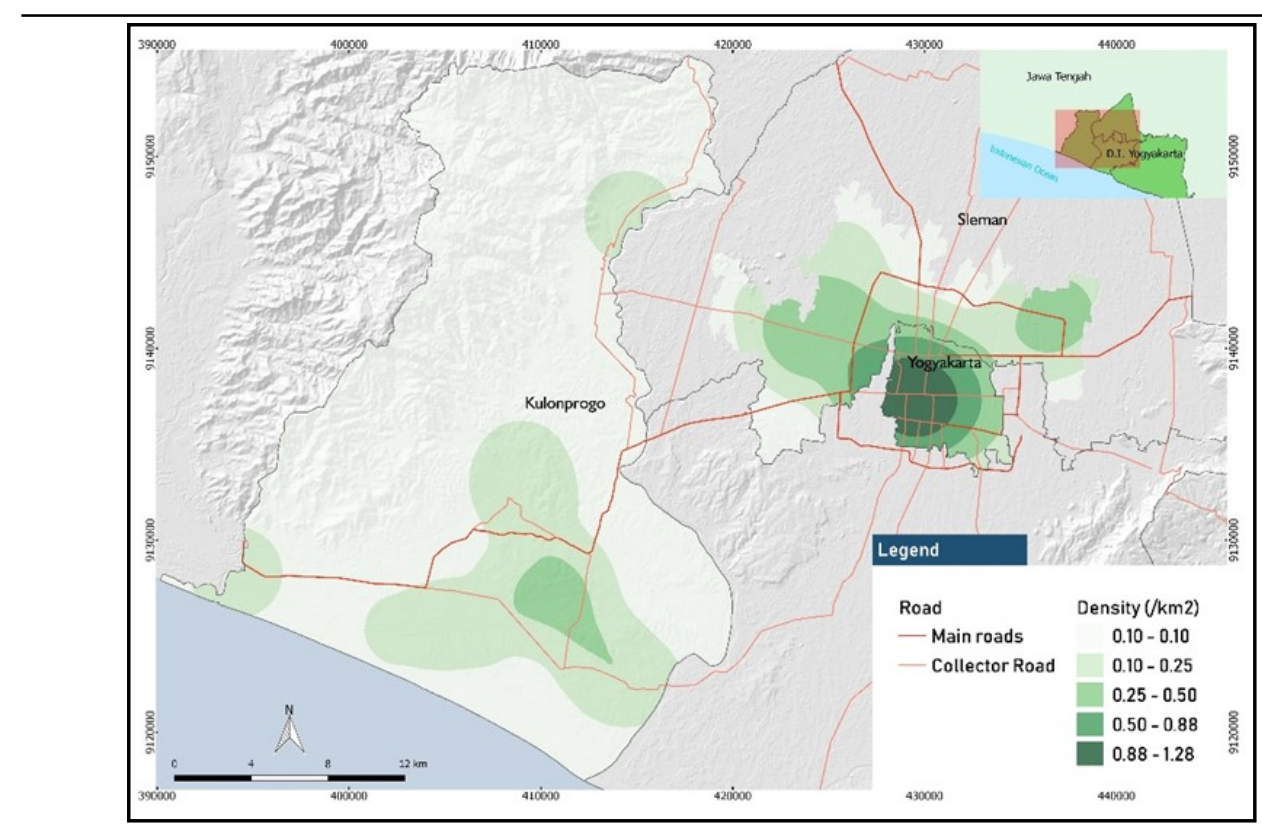

Fig. 11 - Branchless Banking-Agent Customer Density Analysis Map in urban, suburban and rural areas

biggest number of customers is found in the sub-districts of Godean and Depok. The density of customers in the city of Yogyakarta is found the highest if compared with that in other areas. This is because the use of branchless banking services through an agent is effective and customers find closely located to their home the agent of branchless banking services; otherwise there are many bank offices and ATMs found in the city.

The banking activities through an agent can be called running well if there are customers who make use of branchless banking services. Fig. 12 shows that the distribution of branchless banking location is related to its accessibility (topography, distance to the main road, and distance to the settlement). The distribution of agents is seen densely in areas on the sides of arterial or main and collector roads. The distribution of agents is seen densely in areas on the sides of arterial or main and collector roads. The distribution pattern is seen outward or far from the main or collector roads because not all customers live along the sides of both kinds of roads. Meanwhile, the presence of agents in the settlement area is also found so that the distribution pattern of agents density tends to be found in the surrounding areas of the main and collector roads that are getting far from the road.

Location is the main factor for customers to do transactions through agents because they are closer to their home than the nearby bank office. Therefore, the presence of an agent in the settlement area of customers is indeed needed. Besides the accessibility factor, being close to the settlement area, being close to the main road, and being located in flat and slope areas have become important factors for customers to do bank transactions through the agents of branchless banking services.

\section{Conclusions}

The results of the research show that the making use of branchless banking through an agent 


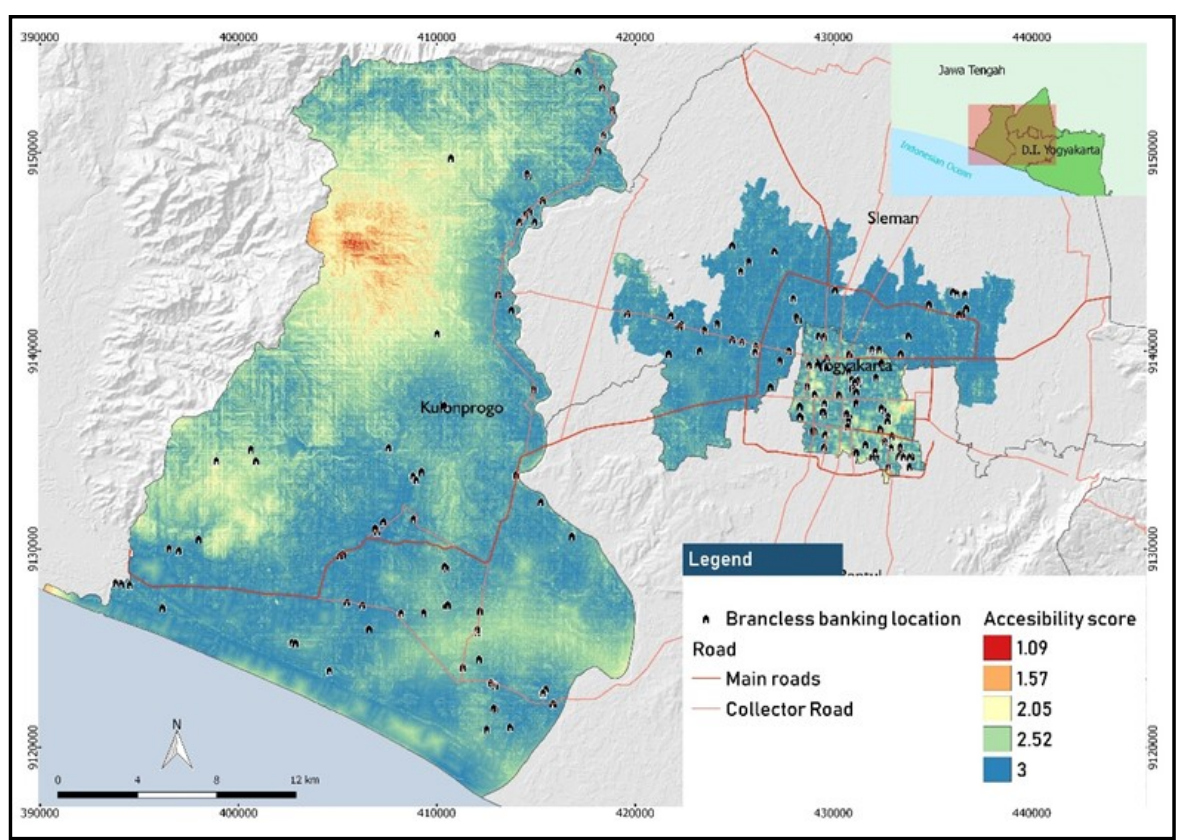

Fig. 12 - Branchless Banking-Agent Accessibility Map in urban, suburban and rural areas

in urban areas is more based on the factors of location close to the customers' home and on easy accessibility. Meanwhile, in rural and suburban areas, besides those two factors, other factors such as cohesive atmosphere and convenience are of primary importance. Agents and customers are mostly found in rural areas than in both urban and suburban areas. Meanwhile, the benefit that the agents get is that they can increase their income. For customers, the advantage that they can get is that they can save their time and costs because the agent is close to their home. The result of map analysis shows that the density of agents and customers is influenced by accessibility while being close to the main road, the settlement, and in areas with flat slope land.

This research proves that branchless banking through an agent that is adopted by banks in Indonesia has given the main benefit of enlarging bank products that were previously accessed only at the branch office of banks (bank branching) while customers had to spend higher costs for transportation. Branchless banking service through an agent is acceptable because it offers benefits to the customers and additional revenues to the agents. Such services will keep growing along with the growth of e-commerce business and transactions due to the increase of ICT use.

\section{Acknowledgments}

The research was funded by PUPT 2017 scheme. We would like to thank Universitas Gadjah Mada and Higher Education Directorate of Indonesia. Thanks also go to the blind reviewers for the comments to improve the manuscript. 
The Advantages and Analysis of the Location of Branchless Baking in Urban and Rural Areas in Yogyakarta Special Region, Indonesia

\section{References}

ABBAS S. S., MEHMOOD B., ABBAS S. F., SAIR S. A. (2015), Quality of Branchless Banking Service in Lahore City: Application of Servequal Model, Sci.Int(Lahore) 27 (2), 14871491.

AGARWAL S., HAUSWALD R. (2010), Distance and Private Information in Lending, The Review of Financial Studies 23 (7), 2757-2788.

ANAND M. B., SREENIVAS D. L. (2013), A Study on Branchless Banking in India, International Journal of Development Research 3 (8), 1-6.

ANSONG D., CHOWA G., ADJABENG B. K. (2015), Spatial Analysis of the Distribution and Determinants of Bank Branch Presence in Ghana, International Journal of Bank Marketing 33 (3), 201-222.

BHAT C. R., SIVAKUMAR A., AXHAUSEN K. W. (2003), An Analysis of the Impact of Information and Communication Technologies on Non-Maintenance Shopping Activities, Transportation Research Part B: Methodological 37 (10), 857-881.

COHEN G., SALOMON I., NIJKAMP P. (2002), Information-communications technologies (ICT) and transport: does knowledge underpin policy?, Telecommunications Policy 26 (1-2), 31-52.

DERMISH A., KNEIDING C., LEISHMAN P., MAS I. (2012), Branchless and Mobile Banking Solutions for the Poor: A Survey of the Literature, Innovations: Technology, Governance, Globalization 6 (4), 81-98.

DINIZ E. H., POZZEBON M., JAYO M. (2009), The role of ICT in helping parallel paths converge: microcredit and correspondent banking in Brazil, Journal of Global Information Technology Management 12 (2), 80-103.

DZOMBO G. K., KILIKA J. M., MAINGI J. (2017), The Effect of Branchless Banking Strategy on the Financial Performance of Commercial Banks in Kenya, International Journal of Financial Research 8 (4), 167-183.

THE ECONOMIST (2002), China - The withering away of the party: Economically, but not politically, Retrieved from: https://www.economist.com.

IVATURY G. (2006), Brazil's banking correspondents, in: Mathison S. (ed.), Electronic Banking with the Poor: Increasing the Outreach and Sustainability of Microfinance through ICT Innovations, The Foundation for Development Cooperation, Brisbane, pp. 53-57.

FRANKSISKA R., PURWATI Y., NUGROHO P. I., WIDODO A. (2017), Driving and Inhibiting Factors of Branchless Banking Technology Adoption in Rural Community, KINERJA 21 (1), 35-47.

JAYO M., DINIZ E. H., ZAMBALDI F., CHRISTOPOULOS T. P. (2012), Groups of services delivered by Brazilian branchless banking and respective network integration models, Electronic Commerce Research and Applications 11 (5), 504-517.

HINSON R., OWUSU-FRIMPONG N., DASAH J. (2009), Key motivations for bank patronage in Ghana, International Journal of Bank Marketing 27 (5), 381-399.

KARLAN D., MORDUCH J. (2010), Chapter 71 - Access to Finance, in: Rodrick D., Rosenzweig M. R. (eds.), Handbook of Development Economics, Elsevier, Oxford, pp. 47034784.

KAZI A. K., MANNAN M. A. (2013), Factors affecting adoption of mobile banking in Pakistan: Empirical Evidence, International Journal of Research in Business and Social Science 2 (3), 54-61.

KING B. (2018), Branches Have a Strong Future as Alternative Channels, BBN Times, Retrieved from: https://www.bbntimes.com.

MAS I. (2009), The Economics of Branchless Banking, Innovations: Technology, Governance, Globalization 4 (2), 57-75.

MUTHINJA M. M., CHIPETA C. (2018), What Drives Financial Innovations in Kenya's Commercial Banks? An Empirical Study on Firm and Macro-Level Drivers of Branchless Banking, Journal of African Business 19 (3), 385-408.

NAM T., PARDO T. A. (2011), Conceptualizing Smart City with Dimensions of 
Technology, People, and Institutions, The Proceedings of the 12th Annual International Conference on Digital Government Research, 282-291. OTORITAS JASA KEUANGAN (2014), Strengthening Economic Foundation Through Financial Inclusion, Retrieved from: https://www.ojk.go.id/. OTORITAS JASA KEUANGAN (2017), Laku Pandai (Layanan Keuangan Tanpa Kantor dalam Rangka Keuangan Inklusif), Retrieved from: https://www.ojk.go.id/.

RACHMAWATI R. (2009), ICT Based Services in Bank Sector and Its Benefit For Citizens in Yogyakarta Municipality, Indonesia, Proceeding of International Industrial Informatics Seminar (Book 2) 1 (1), 113-118.

RACHMAWATI R., ETTEMA D., RIJANTA R., DJUNAEDI A. (2010), The Impact of ICT

Use to The Change of Work Pattern and Its Relationship With work Travel, Proceeding World Academy of Science, Engineering, and Technology 66, 2587-2607.

RACHMAWATI R., RIJANTA R. (2012), Population Mobility and Urban Spatial Structure: Does the Use of Information and Communication Technology Matter?, Regional Views 25, 9-19.

RACHMAWATI R. (2013), ICT Based-Urban Economic Services, in: Markandey K., Srinagesh B., Lonavath A. K. (eds.), Challenges of Urbanization in the 21st Century, Volume 1. Amenities and facilities in urban areas, Concept Publishing Company, New Delhi, pp. 267-276. RACHMAWATI R., RIJANTA R., DJUNAEDI A. (2015), Location Decentralization Due to the Use of Information and Communication Technology: Empirical Evidence from Yogyakarta, Indonesia, Human Geographies - Journal of Studies and Research in Human Geography 9 (1), 5-15.

RACHMAWATI R., HAPSARI S. A., CITA A. M. (2018), Virtual space utilization in the Digital SMEs Kampongs: Implementation of Smart City and Region, Human Geographies Journal of Studies and Research in Human Geography 12 (1), 41-53.

REAVES B., SCAIFE N., BATES A., TRAYNOR P., BUTLER K. R. B. (2015), Mo(bile) Money, Mo(bile) Problems: Analysis of Branchless Banking Applications in the Developing World, Proceedings of the 24th USENIX Security Symposium, 17-32.

SANTOSO B., AHMAD K. (2016), Islamic Microfinance Branchless Banking Model in Indonesia, Intellectual Discourse 24 (Special Issue), 409-433.

SHABIRAH I., ALDIANTO L. (2014), The Suitable Model of Branchless Banking Implementation in Indonesia, Journal of Business and Management 3 (6), 633-645.

SILVERMAN B. W. (1986), Density Estimation for Statistics and Data Analysis, Chapman \& Hall/CRC, London and New York.

STILWELL F. J. B. (1992), Understanding Cities and Regions: Spatial political economy, Pluto Press, Leichhardt.

UDELL G. F. (2009), Financial Innovation, Organizations, and Small Business Lending, in: Alessandrini P., Fratianni M., Zazzaro A. (eds.), The Changing Geography of Banking and Finance, Springer, New York, pp. 15-26.

WILSON V. (2014), Research Methods: Sampling, Evidence Based Library and Information Practice 9 (2), 45-47.

Initial submission: 30.10 .2018

Revised submission: 16.03.2019

Final acceptance: 28.05.2019

Correspondence: Department of Development Geography, Faculty of Geography, Universitas Gadjah Mada, Sekip Utara, Bulaksumur, Yogyakarta 55281, Indonesia.

Email: rinirachma@ugm.ac.id 
Journal of Urban and Regional Analysis, vol. XI, 1, 2019, p. $69-86$

\title{
FROM RELIGIOUS SEGREGATION TO CULTURAL HERITAGE. THE CASE OF THE ARMENIAN COMMUNITY IN BUCHAREST
}

\author{
Viore/ MIONEL \\ Bucharest University of Economic Studies, Romania
}

\begin{abstract}
Religious segregation is a process with a very long history, but which has been little analyzed within the Romanian scientific literature. The paper proposes a detailed discussion of how the Armenian community in Bucharest was geographically segregated because of religious reasons by the rest of the Orthodox inhabitants of the city almost five centuries ago. The analysis made by the national and international literature on this subject reveals substantial gaps, with multiple theoretical difficulties in explaining how religious segregation can end up in cultural heritage. Incorporating the urban segregation theory and urban culture, the research proposes an exploratory case study as a conceptual basis for future similar studies. The analyzed data have shown that, in time, due to the expansion of urban space and to certain religious concessions, cities can be the beneficiaries of high-value physical elements with an impact on urban culture, architecture and landscape, all thanks to religious segregation.
\end{abstract}

Key Words: geographic segregation, religion, urban culture, Armenians, Bucharest.

\section{Introduction}

This article uses the data obtained by reviewing and analyzing the theoretical background and other sources of information available online to discuss how the Armenian ethno-religious minority in Bucharest has been the case of a clear geographical segregation for centuries. The main cause of this situation consisted in the theological and religious differences within the host society, which led to the discriminatory behavior of the majority and to addressing the minority as heretical and schismatic (Mihăilescu 2003, Damé 2007). Further on, starting from the observation that some of the Bucharest landmarks and symbols now remind us of the cosmopolitan past of the city, the article analyzes the contribution of the Armenian community to the building of the cultural-historical heritage of the capital of Romania. Not only the Armenian community, but also the other ethnic, religious, socio-professional and other communities and minorities, have their contribution "engraved" in the history, heritage and, above all, the geographical toponymy (Nicolae et al. 2006, Airinei Vasile 2016) of Bucharest. This study proposes an analytical look at a seemingly oxymoronic situation, totally different from that of Bennett (1998), which is a difficult one to accept, since at a superficial look it seems paradoxical and apparently incompatible with the reality of the present, namely that religious segregation has left a rich cultural and architectural dignity to Bucharest.

The research makes a substantial contribution to the scientific literature by combining religious segregation with cultural heritage. The national scientific literature does not know any thorough analysis in this respect, and there is a scientific breakthrough that deserves to be explored. Neverhtheless, the international literature is not too abundant either, and the few attempts that existed have taken into account the broad framework of segregation and cultural heritage (Bohland 1982, Byrne 2003), but without emphasizing their effects on the physical landscape (buildings, monuments, streets, toponyms etc.), a goal of this research itself. As I began to document and collect information, it became obvious that this is the point where the article makes a substantial contribution, and Bucharest offers a consistent methodological model that can be replicated in other geographic areas with similar characteristics. 
As the theoretical background suggests, the case study dedicated to the segregation of the Armenian community in Bucharest can easily be depicted as part of the broad category of social segregation and, particularly, that of socio-urban segregation (Peach 1975), which is narrower in terms of space manifestation. By the importance of the religious component in the conduct of historical events and in the completion of the main purpose of the research, the present study represents an indispensable part on religious (Smith 2001) and ethno-religious segregation (Keene et al. 2016). However, because it contributes to Bucharest's urban research by pointing out the cultural value of the Armenian heritage, the study is also included in the field of urban and cultural material and immaterial heritage theory (Latham and McCormack 2004). In the spirit of the previous idea, Musil's statement (1995: 682) - "The very streets, with all their bustle and their ornate, pompous buildings, seemed to be in an analogous 'expectant state', as if the hard facets of a crystal were dissolved in some liquid medium and about to fall back into an earlier, more amorphous condition" - may become a leit-motif of the Armenian cultural component of this study.

So, based on this information, I will consider the case of religious segregation of Armenians in Bucharest, a situation that began to unfold from the late fifteenth century and it later transformed into cultural heritage. Lots of the urban parts of the city today remind us of the Armenian community (Airinei Vasile 2016). Therefore, the following sections will be dedicated to the theoretical background of this analysis and to determining the causes and ways in which the Armenians kept their separation from the rest of the inhabitants of Bucharest. The final section of the paper focuses on the assimilation and metamorphosis of old religious animosities into present urban cultural heritage.

\section{Urban segregation}

At the end of the first half of the last century, urban segregation became a very attractive subject of analysis for researchers in many areas, the most relevant of the emerging studies focusing on residential segregation (Evans 1934, Marcus and Burner 1936, Myrdal and Bok 1944). From this stage, Wirth (1928) draws attention to the danger of ethno-racial polarization that lurks the American cities, and, at the same time, he highlights the role of worship places in the segregation equation. Later, studies are multiplying by focusing on the increasing urban segregation and fragmentation phenomena, particularly within American societies (Massey 1990), together with the South African (Beinart and Dubow 2013) and Brazilian (Telles 2006) ones as well. Interestingly, Wieviorka (1994: 28), by referring to American cities, states: "American sociologists have contributed - in the broad sense of the term - to the invention of racism". One of the examples he cites in this respect is that of Dow (1929) calling for a gradual segregation of the black population, which ultimately ought to have led to its establishment in a single state. However, it is not to be understood that social segregation is limited to these examples, as it is not the case today. Not only are research papers more numerous, but some of them are looking at very little-known settlements (Ireland 2008), where the idea is that segregation is an urban process that, at least appearantly, knows no boundaries, while other studies refer to the increasing costs of segregation (Carr and Kutty 2008).

The analysis methodology has evolved with increasing research, and theory has become more solid. Urban development has speeded up social polarization processes, so that nowadays, as White (1983) noted, many urban spaces are fragmented, both socially and geographically / physically. Moreover, social segregation affects cities in multiple plans, including racial segregation (Rabinowitz 1994, Jencks and Peterson 2001, Massey and Denton 2003), ethnic segregation (Johnston et al. 2007), socio-economic segregation (Morgan 1975, Narodowski and Nores 2002, Tammaru et al. 2016), educational segregation (Domina 2006, O'Nions 2010) and, last, but not least, religious segregation (Smith 2001, Murtagh 2011, McKeown 2012). All these types of segregation leave a spatial footprint on the urban environment, which would translate into concrete forms of geographical segregation. The literature records many studies 
that have focused on spatial segregation forms such as the slums (Davis 2006), the ghettoes (With 1929, Wilson 1989), the polarized spaces occupied by the urban privileges (Mionel 2012), which symbolically bear the name of the Golden Ghetto (Wagner 1976), as well as many other spatial forms of social segregation (Wievieorka 1994). For example, Harrison (1972) proposes an interesting approach to vocational education and training in urban ghettos, while Hutchinson and Haynes (2018) say that these are a contemporary global issue marked by controversy.

For Central and Eastern Europe, at present, the most pressing socio-urban problem is that of Roma communities (Mionel and Neguţ 2011, Méreiné Berki et al. 2017). This community is affected not only by ethnic segregation, but also by increasing inequality and socio-economic segregation according to the most recent studies (Tammaru et al. 2016). Segregation has prompted some authors to talk about racial cities (Picker 2017) within which the Roma concentration gave rise to vicious spaces of marginalization, poverty, stigma (Mionel 2013) and racism (Cashman 2017). For example, one of the top quoted contemporary specialists in the field (Wacquant 2013), evidences ethnic and racially marginalized groups - a situation in which the Roma are included - which appear to be urban outcasts. In this state of affairs, a defining contribution has also been given to Chelcea and Druță (2016), talking about zombie socialism and the rise of neoliberalism in post-socialist societies. Moreover, some voices supporting the existence of solid connections between segregation and attachment to the place appeared in Central-Eastern Europe (Málovics et al. 2019). In the authors' opinion, this relationship is very strong and contradictory at the same time and it is based on the social relationships within the segregated communities, on the characteristics of the neighborhoods landscape and on the processes that our society is currently facing as a whole.

\section{Urban religious segregation}

The existing differences between certain religious communities at the moment of interaction may generate various types of segregation, as it is the case of ethnic, rasial and economic differences within other similar communities. Generally speaking, religious segregation represents the division of the population according to their religion. This concept has been applied in cases where religion has caused a spatial rupture within the population, creating a true social phenomenon (Knox 1973). In the same line of thought, in order to define this social phenomenon in his analysis on the situation in Pakistan. Akkara (2000) used the expression: 'religious apartheid'. Almost any scientific analysis that focuses on religion beliefs and rationality (Attfield 1970), ethno-religious segregation (Adair et al. 2000, Murtagh 2011) and sectarian politics and segregation (Damluji 2010) raises a number of fundamental issues. Due to the delicacy of the subject and of religion in particular (Smith 2001), such themes are not paid too much attention by the non-theological academic community. Therefore, when bringing up the question of dividing religious communities, polemics often arise (Hutchinson and Haynes 2018). Such situations arise precisely because of religious beliefs that - in most cases preach justice, understanding and, above all, what we are very interested in analysing, 'living together'. In other words, although this has been happening since antiquity, denomination should not cause divisions within the community.

To elucidate a somewhat religious segregation problem, we have found first an answer to the question: 'can religion divide or cause population segregation?'. Well, many people have tried to answer this question that was launched by a U.S. website. The opinions have largely inclined towards a dual response, which shows that, on the one hand, religion unites people, and, on the other hand, it separates them; however, it is up to the individual to take one side or the other. However, at the individual level, religious separation is insignificant compared to the attitude a human group may adopt, especially since the implementation of the process is carried out in urban areas. The diversity of urban, social, cultural behaviours and so on, makes 
it very difficult for human groups to take position in one context or another. There is no novelty that individuals naturally presenting similar features tend to occupy similar spaces and to behave in quite a similar manner, especially if they are the result of immigration (Wieviorka 1994). However, this depends on the people belonging to that group (Mionel 2012). The same happens with religion, in the sense that when the number of supporters within the city is large, they are concentrated in urban areas (Gale 2013), usually around the place of worship, causing a geographic area segregated on religious grounds (Flint 2010), but when the followers are few and scattered in space, we cannot talk about segregation.

The polarizing behavior generates an emergence of distinctive religious landscapes, which has also been seen by some as "a signifier of (possibly immutable) cultural difference" (Phillips 2006: 27). But, on the other hand, there have also been cases which make us think about the ancient and medieval policies of religious separation of social groups. An American court ruled that authoring a school unit to coincide with the religious boundary of a neighborhood is to the advantage of religion. Thus, that fine line of the voluntary association on religious grounds, which I mentioned earlier, was overcome by imposing an explicit political limit on the basis of the people's belief by the authorities (Norgren and Nanda 2006).

Beyond the theoretical side presented above, specific cases where urban society was divided on religious reasons come and support the claim that this process has affected and still affects some cities of the world (Adair et al. 2000, Murtagh 2011), sometimes in combination with other forms of urban segregation (ethnic, racial, etc.), and other time independently of those (Mionel 2012). Where large numbers of immigrants are present, as it is the case of Western cities, this process is likely to occur. Most often, groups from Muslim countries (Gale 2013) are prone to separation of religion because that culture focuses on the Koran ideology of behaviour or lifestyle (Holden 2009). Examples like these are the British cities (particularly London, which is more than eloquent): "the British capital is much more segregated on religious grounds rather than racial (...) a dramatic map outlined by researchers at University of East London shows how London has become a 'pot' of religious enclaves and that minority religions in some areas reach $80 \%$ of the population" (24DASH 2007). According to Steele (2005), columnist for the The Guardian, another particular case is that of cities in Bosnia and Herzegovina, which are geographically split into three denomination categories: Muslims, Catholics and Orthodoxs. Also, the new urban trend in Lebanon reveals new denominational residential models, as shown in the study by Glasze (2006). The perpetual crisis that has ruined the Near East for over seven decades or the Israeli-Arab conflict has led to a strong polarization of cities and to a vertical (ethnic, confessional, religious etc.), as well as horizontal, segregation, that is to say, to neighborhoods that are more homogeneous from a religious point of view. According to Agbaria (2018), the situation in Israel is called religious ethnonationalism. Similarly, the traces of the conflict and, at the same time, their impact on religious segregation are visible today in both Ireland (Shirlow 2016) and Iraq (Corvalan and Vargas 2015), Bosnia and Herzegovina, Lebanon and many other cases. Similar examples can be found not only in the West or in the Middle East, but also in Africa (Sedra 1999, Gambo and Omirin 2012).

\section{Cultural heritage}

Calame (2011) emphasizes religious segregation in his valuable work that speaks of divided cities. Not only does it analyze the conflicting history of concerned cities (Belfast, Beirut, Jerusalem, Mostar and Nicosia), but it also makes an explicit reference to the cultural heritage of the communities that inhabit them. Conversely, according to Freeman's study (1999), cultural inheritance can influence residential patterns and it can predispose urban space to segregation. For example, if we take the correct assumption that the manifestation of different forms of segregation imprints space, as suggested by Byrne (2003), then it is no doubt that its landscape dimension undoubtedly influences cultural heritage and practice. 
In accordance with the examples mentioned so far, historically, Central and Eastern Europe also faced multiple ethnic segregation situations on ethno-religious principles (Keene et al. 2016). The Jewish community is the one that suffered the most from this point of view, and the literature that was dedicated to it is witnessed (Hsia and Lehmann 1995, Paudice 2014). Similar to the segregation of the Armenians in Bucharest, the Jewish medieval ghetto, after Hoffmann (2008), left a rich historiographical and cultural legacy. Further east, in the former Russian Empire, the same minority was forced to live in a clearly defined space perimeter, roughly in the geographic area occupied today by Eastern Europe, with no permission to defend this space than under entirely different conditions (Solzhenitsyn 2004). Their cultural dignity, which Caffyn and Lutz (1999) rightly claims to have been oppressed, as well as other minority groups that have existed or have migrated to Europe during the last centuries (Tunbridge 1994), are now observed everywhere in cities which have formed substantial communities. Wirth's statement (1928), which says that segregated urban landscapes are constituted as cultural communities that express a common heritage of traditions and feelings, is as valid as a decade ago. And what he believed about the segregation of Jews in American cities, namely gravitating around religious life (Wirth 1928), can easily be applied to other ethno -religious minorities, and the spatial footprint is visible today, most often, in the form of places of worship and of what Epstein and Kheimets (2000) called as cultural segregation.

\section{Methodology}

This article focuses on implicit or explicit religious segregation (Norgren and Nanda 2006), a social process with a conceptual age and significant dynamics, as we mentioned earlier. Using the case study methodology (Tellis 1997, Yin 2017), we discuss how the long history of religious segregation is transformed into cultural dignity and how it deletes the collective mentality of the separatist relational legacy of socio-urban groups. According to the data and information gathered from various sources, the Armenian minority, at the heart of the historical process of religious segregation, has increased slightly over time, but with it the assimilation process has also accelerated.

The research has gone on for a long period of time and it has embarked on several discontinued stages. The first step, the most consistent one, occurred about ten years ago, during my $\mathrm{PhD}$ study, when I investigated urban segregation in Bucharest. The sources of documentation were numerous and very varied: historical sources, ethnic studies, scientific articles, and others. At this stage, historical documentation (Kipping et al. 2015) was decisive, and the main purpose was to find out what and if ethnic communities were structured in space. The second stage started in 2013, with the occasion to attend the International Conference on Romanian-Armenian Cultural Heritage, organized in Bucharest by the Ministry of Culture and the Romanian Academy (Hayern Aysor 2013). Using the data from the previous stage, I continued to gather information to support the hypothesis - derived from the information already collected - that the Armenians in Bucharest received discriminatory and segregating treatment from the city administration and the Orthodox Church at that time, and implicitly, from its parishioners. The third step is the most recent, and it involved the correlation of information on the old locations and spatial developments of the segregated community with the elements of the current urban framework that recall the past events and which, within a tourism perspective, could generate valuable capital (Isaac 2009, Jackson 2010).

This research is, above all, an exploratory one (Stebbins 2001), which seeks to pave the way for other studies with similar themes. For a comprehensive understanding of the relationship of religious segregation with cultural heritage as a subject of research, this paper critically reviews the scientific articles published in various national and international scientific journals circumscribed to urban space. Articles in peer-review and scientific books have been considered to be some of the best sources of information for this study because they provide 
the most current, stable and reliable academic source of information. As Bowen (2009) said, this method is a cost-effective means of collecting information, as well as a method that remains unchanged and unaltered by the research process or the presence of the researcher. Last but not least, in the literature analysis section, the study takes the form of a systematic quality review, following a specific protocol, for a more scientific approach (Sandelowski 2008), thus ensuring a more accurate and detailed image of the literature on religious segregation and cultural heritage.

\section{Results and Discussion}

\section{Armenians - a long-lasting presence in Bucharest}

Formed later than communities from Moldavia - which served even in the Romanian army (Egner 2016) - and Transylvania (Gazdovits 1996, Albinetz 2012), the Wallachian Armenian community has a newer history and thus it is poorer when compared to the other two. This has not prevented the community to have a "heightened vitality". 1400-1435 is the approximate time interval to determine Armenians in Bucharest, according to Terzian (2001). They are certainly among the first aliens who arrived in the Romanian space since the late fifteenth century: "they have already settled in different Wallachian cities. They are in Bucharest, Târgovişte, and in Râmnic" (Ionescu-Gion 2003: 444). Going in the same direction, Majuru (2008: 138-139) admits, with some uncertainty: "Armenians seem to be the first to arrive in the Romanian area they are certified in 1421 to Cetatea Albă". Anyway, within the range of historical events, it is certain that the oldest mention on paper of the Armenians across the hearth of Bucharest dates from the seventeenth century: "Armenian slums are mentioned in documents of the seventeenth century. There, and they had a church" (Ionescu-Gion 2003: 230). Therefore, we can only accredit Giurescu (2009: 512) when he affirms: "an old and important colony in Bucharest was formed by the Armenians". Majuru (2008: 13) believes that, between 1650 and 1700, Armenian slums are emerging into the fair area: "on the north bank of Dâmboviţa, merchant slums existed, such as Sf. Vineri, Răzvan, St. Ion Nou, Olteni, Serbians, as well as the Armenian slum" (Majuru 2008: 13). Moreover, the documents quoted by Giurescu (2009) certify that the Armenians lived in Bucharest in 1640, while in the eighteenth century, news and notes on the Armenian community multiply.

Paul Strassburgh (Ambassador to the king of Sweden) notes, together with his visit in March 1632, that Bucharest is a very large city where "merchants of all nations live together: Greeks, Armenians, even Turks" (lorga 2008: 57). According to Giurescu (2009), during the reign of Prince Leon (1632), all city streets and markets alike were full of goods that Italian, Greek, Armenian and Turkish merchants exposed for sale. And, it is undeniable that until the eighteenth century trade was in the hands of foreigners in the town along the banks of Dâmboviţa river, Armenians holding an irrefutable role in this area, as it is pointed out in the following passage of Damé (2007: 53): "Saxons came to Bucharest, Sibiu and Brasov, Armenians, Turks, Greeks like to bring all their (...). For the people, foreigners meant heathen Turks, Armenian heretics, Jews, Protestants and Catholics". Although sedentary long before the eighteenth century, the Armenians are, according to Damé (2007), not only 'heretics', but they are also still 'foreigners'.

The age of the Armenian presence in Bucharest is strengthened by their payment of taxes since the sixteenth century, and the physical elements present in the space, such as (for the same century) "towards the south (...) the Armenian stone pillar" (Ionescu-Gion 2003: 139). The peers that delimited the border of Bucharest city in mastering its metropolitan hearth recorded the Armenian stone pillar located in the south-east out of town, near Giurgiului road and Şerban Vodă pond, in the act of June 1, 1668 (Terzian 2001, Ionescu-Gion 2003). Moreover, lorga (2008: 115) records: "there are Armenians... on an Armenian Lane (...) and they do business with the Turks". That is, in Bucharest, in what taxes are concerned, the merchants were divided 
into "Romanian merchants, Braşov dwellers, chiprovăceni, Armenians and Jews, [who] contributed according to their needs, and contributed almost to everything" (lonescu-Gion 2003: 452). Ionescu-Gion (2003: 452) confirms that, between 1689 and 1714, "the contribution is made according to everyone's possibility (...) 200 plates for the Armenians".

It is well known that the Armenians were great traders of coffee and tea (Florescu 2008), as they were "specialists" on this (Giurescu 2009). In short, they were coffee traders, hence the saying "when an Armenian arrives in a city, the first thing to do is have coffee (so as to verify the standard of living by the liquor's quality) and then go to the Armenian Church (if there is such a place of worship in that city)" (Antonian 2011). In addition, a register book from 1832 contains "38" coffee traders "out of which 16 are Armenians according to their names" (Giurescu 2009: 542). Finally, a special category was made by "the Armenian silk traders", mentioned in the privilege given to the Dyers Guild, dated August 18, 1824 (Giurescu 2009: 580).

The Armenians had good trade relations and business relations with the Turks. Regarding the locals' initial aversion to religion on the Armenian heretics - as Damé (2007) called them - and regarding the commercial activities they practiced, it is stated: "there was a nameless grief in Bucharest, when people saw and heard that the Turks sell in the Hebrew and Armenian market lamps, bowls and holy vases from the cathedral in Târgovişte" (Ionescu-Gion 2003: 158). These events mark an important point in what I will develop in the following sections. From the quote, we can see that no foreign interference in the natives' religion was acceptable, especially coming from the Armenians who were considered heretics, so schismatics (Mihăilescu 2003) for the local orthodox Christian church at that time. Such events were probably preceded by an order settling the Armenian community outside the city in a peripheral well-defined and geographically segregated area of Bucharest. Despite all the misunderstandings, disagreements and tensions between the local and indigenous communities, by the end of the twentieth century, trade still remained in the hands of the outsiders arrived in Bucharest (Ionescu-Gion 2003, Giurescu 2009, Damé 2007, Majuru 2008).

\section{Historical background of urban religious segregation}

Once established in Bucharest, Armenians form a significant community both because of their numbers and the economic power they exhibit (Mihăilescu 2003, Majuru 2008). From the point of view of religions, in 1878, Bucharest has a population of over 177000 inhabitants divided as it follows: "Orthodox - 132 987; Catholics - 16 991; Protestants - 5854, Armenians - 790; Lipoveni - 206; Hebrew - 20 749; Mohammedans - 43; various - 20" (Damé 2007: 143-144). The number of Armenians remains almost unchanged, since the same author recorded about 700 Armenians in Bucharest, according to statistics in the year 1906. Mihăilescu (2003) lets us better understand how the Armenians were concentrated in Bucharest after being incorporated by the city during successive increases. In the year 1860 (Fig. 1), a number of over 520 Armenians is concentrated in the vicinity of Calea Moşilor, and the rest are in other urban areas. In fact, only here the Armenians - around their old slum - had great economic significance.

\section{The religious origin of the Armenian segregation: theological differences}

Due to its quasi-hermetic nature (linguistic, and religious especially) kept for a long time, the Armenian community has managed to attract antipathy in Bucharest. Any relationship with the Armenians and their religion is very good now, but the same cannot be said about the beginnings of the community - the XVth and XVIth centuries - in Bucharest area. Because there were doctrinal differences, which were minimal, it is true, to the Orthodox faith, the Romanian Orthodox Church did not accept them into the city centre with the other people, thus isolating them. Therefore, the population, that would mosly follow the church dogma, did not take a different view on the issue. 
Viorel MIONEL

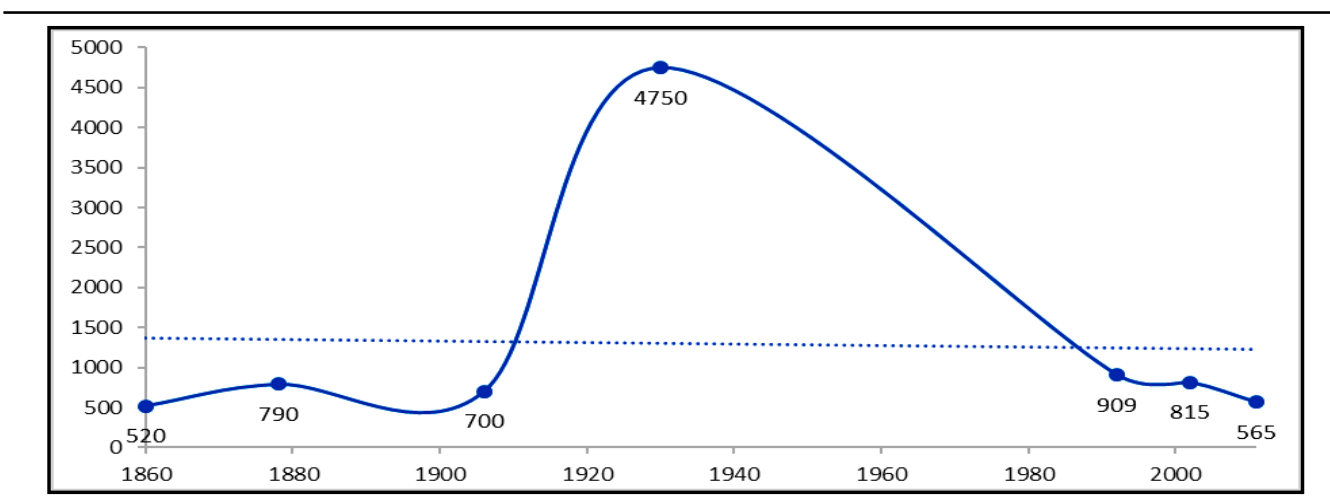

Fig. 1 - The evolution of the number of Armenians in Bucharest over the last 150 years

Source: various compiled data

The Armenian Apostolic Church was among the churches that separated from the universal church, along with other churches: "the full separation of western and eastern neighbours, so religious and national isolation, this is the cultural characterization of Armenia made during the fifth and sixth century" (lorga 1913: 8). These churches - and therefore their believers - are known as anti-Chalcedony, old Orthodox, or Oriental churches. In an interview (Şchiopu 2009), writer Paul Bogdan, who is also pastor of the Armenian Church of the Archdiocese of Bucharest, reveals, most likely, the real reason for discrimination and sagging the Armenians outside the city from the beginning. The Armenian pastor noted that the Armenian Apostolic Church (and therefore the Armenians) "was blamed of being heretical" (Şchiopu 2009). A strong argument for this finding is - in his opinion - that "at Voroneţ (...) the Armenians [are] painted by the Turks. These differences are based on the antipathy of Greek origin" (Şchiopu 2009). The Turks, according to Damé (2007), were neither more nor less than pagans therefore associating or putting together the two ethnic minorities denotes the Romanians' disparagement. The Armenians have been, from ancient times, in a dispute with the Greeks, as the latter attempted to introduce the Greek language as a ritual one. Thus, the only possible detachment was a doctrinal or theological distinction. Let us not forget that even the name of the religion derives from Greek, from the two words: 'ortho', meaning straight and correct, and 'doxa', which means learning, knowledge. Therefore, the right doctrine or orthodoxy is the correct one.

When analysing the religious relationship between the Armenians and the Bucharest citizens, an important element on segregation is the hermetic character of the Armenian community during the fifteenth and sixteenth centuries, when they began to make their appearance and settle in Bucharest. As a specialist considers, the Armenian Apostolic Church, which is a purely national church, that supports the destiny of one nation (Enache 2011), i.e. the Armenians, was not acceptable for the leaders of the Orthodox Church.

The Armenians hold the same main religious holidays as the Orthodox Romanians. However, through the theological differences mentioned above, the Armenian Orthodox and the Bucharest Orthodox citizens, include Christmas celebration. Orthodox Armenians everywhere celebrate Christmas on January 6 (Epiphany once) and not on December 25 according to the local Orthodox rite. In fact, by celebrating Christmas and Epiphany on the same day, Armenians kept the original traditions of Christianity (Vosganian 2012). Until the nineteenth century, another important theological distinction was given by Easter. Resurrection was celebrated (as it still happens in other states) with the Catholic. To no longer be considered heretics because of the separate celebration of Easter, the Armenians claimed and obtained exemption from the Supreme Patriarch, and since then this change is respected. It should be 
added that the monastic life was of a very traditional nature to the community. Not everyone could become a priest or a monk, but that one who wanted to give his life to the service of God should have come from the ranks of the wealthy Armenian ranks, a rule that was probably sent to Bucharest.

\section{From theological differences to geographic segregation}

As for Bucharest, the church was closely related to the Greek one. The same happened to the monasteries which owned one quarter of the arable land before the secularization in the nineteenth century. Bucharest was also "owned" by the Orthodox Cathedral, and that is why the church's administrative influence was exercised over the city and its inhabitants. There were also religious services which were held in Greek and Slavic languages in many churches. Hence the incompatibility between the Armenians and the Greeks (who influenced the Romanian Orthodoxy) as mentioned above, that harboured a religious dispute since the fifth century. Lacking an alphabet until the fifth century, the Armenian community was forced to listen to their liturgy instantly translated in the church. The priests were holding the Mass in Greek and a few scholars were simultaneously translating into the Armenian language for the people (Şchiopu 2009). After the fifth century, the Armenians created their own alphabet and this is when religious differences and divisions appear, and they come to Bucharest with the arrival of the Armenians. Nevertheless, the Orthodox Church wanted nothing but their conversion to Orthodoxy.

Even if the historical data does not record such events in Bucharest (except their physical separation from the Bucharest citizens), Paul Bogdan says that, on the territory of Romania "[there] is historical evidence that the Armenians were victims of a small pogrom under Ştefăniţă Vodă. They were expelled from their homes, tortured, their ears were cut off, only to return to Orthodoxy" (Şchiopu 2009). By comparison, in the same century (the sixteenth) in which Ştefăniţă Vodă ruled Moldavia, it is recorded that the Armenians started to settle in Bucharest. Their acceptance by the church and by the Bucharest inhabitants was not less hostile than in other regions of present-day Romania, but it was certainly less painful stinging in a physical sense. In other words, the Armenians in Bucharest did not undergo the torture from Moldavia.

Therefore, due to the religious prejudice of Romanians in Bucharest, the Armenians "have been considered schismatic and isolated for a long time" (Mihăilescu 2003: 143), and they first settled outside the city as "they were forced to inhabit the periphery of the fair, close to Calea Moşilor" (Mihăilescu 2003: 147): "Tradition says that once, when the Armenians came to Bucharest, the Patriarch of the country, knowing them as defile, threw them out of the town so as to build churches and houses, isolating them from the true Christians, just as the Jews were isolated in ghettos or 'Judengasse' in other cities from Italy and Germany" (Ionescu-Gion 2003: 381). The analogy to the most famous ghetto in history, the one in Frankfurt am Main (Wirth 1928 ) is not random. The Armenians of Bucharest, just as Jews in Frankfurt (Fuchs and Krobb 1999), were forced to settle away from the excitement of the city centre. The Armenian segregation took physical, even geographical forms. The 'Judengasse' in Frankfurt am Main was created "by the decree of the king [and] was located in a less inhabited area, far from the residents' homes (...) on the bank of a canal that drained stretched along the old city wall" (Wirth 1928: 76).

Ionescu-Gion's notes (2003) on this matter could be irrelevant, if we did not take into account Damé's (2007) and Caselli's ideas. The French scholar comes and strengthens lonescu-Gion's allegations (2003) in these words: "in Bucharest the Armenians were treated like the Jews in the middle ages: they were forbidden to live in the city. They had to settle outside the borders of the city, where they established their neighbourhood... that is still called the Armenian slum" (Damé 2007: 22). Caselli - the one who has dealt with the rubric "What were once Bucureştii" in the Municipal Gazette (Orăşanu 2003), until his sudden death - wrote in the 
pages of the issue of August 19, 1934: "In fact, in the time when the Armenians were thrown out of the city to build churches and houses, the last slum outside of Bucharest was Father Hierea's slum, who was then the city barrier. The Armenians settled beyond the city barrier - at the time, but to this day we do not know well - and began to build their homes" (Terzian 2001: 4).

\section{The old Armenian settlement and assimilation}

Despite their separation, the "Armenians passed through massacres and wanderings, bearing the label of stateless people accustomed rather to sneak unnoticed, to whisper and to go live in wisdom (...). They learned to live smothered" (Vosganian 2009: 90). The previous fragment fits the Armenian community in Bucharest quite well and it proves that the "smothered life" meets our view of the Armenians living in Bucharest who were forced to live separately from one another, thus segregated, which made them feel different.

With time, however, the successive increases in the urban geographical area included the space occupied by the Armenian suburb in the hearth of the city. This event happened in the eighteenth century. However, at the end of the nineteenth century and the beginning of the twentieth, a significant number of Armenians came to Bucharest. The first Armenian migration flow came from Turkey due to persecution and massacres that occurred during this period in the Turkish Empire and the second was recorded after the World War I, which entirely consisted of refugees (Giurescu 2009). Without decreasing absolutely, the Armenian community started to reduce its number of members.

As previously appreciated, as time went by, the Armenian community became less and less important in terms of spatial concentration. The most important factor in the assimilation process was the mixed marriages between the Armenians and the other Bucharest residents (Giurescu 2009), on the one hand, and the religious concessions which approached the two groups, on the other hand. One example is the statistics of 1899 when the Armenians, along with the Gypsies, were placed in the category dedicated to registered Romanians. This implies whether that their number was very small and therefore not given attention or that they were in an advanced state of assimilation, this time prompting authorities to register them as Romanians. The first version does not count as relevant as long as there are 91 English in the statistics. The Armenian community included many more members at the time. Therefore, the second hypothesis proves to be credible given that, nearly 40 years earlier, the Armenians are separately registered. The same goes for "the statistics" in 1779 (Mihăilescu 2003).

The urban heritage of ancient Armenian slums, left once outside the city, is portrayed by Vintilă Mihăilescu (2003). This author wrote, in his Bachelor paper, that the midway neighbourhoods and the Armenian "houses have, in general, the right height, whether a monotonous or an original appearance (...) there are often crooked and narrow streets (...) that you can hardly steer through them" (Mihăilescu 2003: 12). Also, when analysing the streets arrangement in 1978, the author mentions the Armenian village slum - evoking a "so confusing" street morphology that you can find yourself lost.

Prior to the description made by Mihăilescu in the twentieth century, the area occupied by the Armenians appeared different. Besides narrow, dirty and twisted streets, the Armenian slum landscape was filled with many shanties. Even the merchant shops were themselves rather miserable hovels which only needed one spark to turn them into ashes (Damé 2007).However, in 1914 the past shapes or the foreign spirit of estates hardly escaped Westernization and they are met completely misplaced in the midst of new buildings, "right in the streets if the city centre (...) in the Armenian suburb" (Mihăilescu 2003: 14). To better understand what followed after the assimilation process, we should take a look at the new living space. For example, Majuru (2008: 54) suggests the case of Dămăroaia peripheral neighbourhood. Therein, among the ethnic minority populations between 1930 and 1960, there were Jews, Armenians, Russians, 
Italians, Hungarians, Germans, etc. We infer, therefore, that the Armenians are no longer a compact community as they used to be in the past. With time, among the ethnic Armenians living in Bucharest, there are weak spatial relationships, but strong cultural relations. The Armenians ensured that their institutions and cultural legacy components are preserved and even developed in the spirit of maintaining alive the memory of ancestors who arrived in Bucharest.

Although they were never very numerous, the Armenians have developed a great culture. In 1930, less than 4750 Armenians lived in the city, representing $0.74 \%$ of the population of Bucharest at that time. Moving further to their statistical situation, after the 1989 revolution, at the first census achieved only three years after this unwelcome event, the capital recorded 909 Armenian people. Otherwise, if we refer to the year 2002, their number barely lifted across the country to nearly 1800 people, most of whom were part of mixed families, which is, incidentally, a good example of assimilation. Bucharest barely accounts for 815 people in this census. As for the 2011 census, only 565 inhabitants of the capital were also declared to be of Armenian origin (National Institute of Statistics 2012). At the same time, the average of the inhabitants of the Armenian community was placed in the last century and a half around 1300 ethnicities, due mainly to the contribution made by the migratory flow resulting from the Armenian genocide during the First World War, easily observable on the graph. The constant decrease in the number of Armenians can be seen in terms of changing cohabitation behaviors between themselves and the majority population and, more importantly, the emergence of cultural affinities. The situation which in the past divided, with the passage of time, worked in the favor of their integration and, then, of their assimilation. The trend shown in the graph goes to a quasi-total assimilation, but their cultural memory will remain permanently rooted in the landscape of Bucharest due to the aspects developed below.

\section{Armenian cultural heritage in the twentieth century and the beginning of the $21^{\text {st }}$ century}

The Armenian cultural life is therefore of inestimable value. The Armenian Community in Bucharest founded a school in 1817 to strengthen the cultural bases and, respectively, to keep alive the spirit of the Armenian education (Diradurian 2002). Benevolent associations have played a role in the life of this community. In the Armenian spirit, the 'Rozy foundation' was created for help, education and cultural preservation among the youngsters, according to Majuru (2008). And between 1833 and 1840, a cultural society called Ararat was created, which is present to this day in the local community. But not the same thing happened to the Romanian-Armenian Commercial Bank opened in the eighteenth century.

Of inestimable cultural and religious value is the Armenian Church (Jeamgocian 2015). Erected in 1638 out of wood, it was replaced nearly fifty years later, according to Giurescu (2009: 514), by a brick church financed with "the money of the rich Armenian Adrianople". Spiritual life today originated in the monumental church built between July 24, 1911 and September 6, 1915, in the area of the old Armenian neighbourhood at the corner of Carol I Boulevard and the Armenian street (Stoica and lonescu-Ghinea 2005). Or, as noted by Giurescu (2009: 514), "in «the Armenian slum» next to the Armenian lane", as recalled by an old song in Bucharest: "There is a noble mansion on the Armenian lane»". The homonymous street also reminds us of the Armenians' presence in the Bucharest urban area.

All these Armenian landmarks in Bucharest urban culture appear today as a repayment to the religious injustices of the past and to urban segregation. The Armenian urban landmarks are well ingrained in the collective mind of Bucharest citizens today, being a true "brand" of urban culture because of their age. We cannot talk about the Armenian community in Bucharest without mentioning the famous Manuc Bei and his inn full of history and architectural beauty. Therefore, a prominent representative of the Armenian community in Bucharest was Manuc Bei, thanks to his wealth. Few people know the real name of this rich merchant, named 
Emanuel Mirzaian. He had lent money to the country twice, once the sum of 100000 pans, and 60000 pans, the second time. Among other things, Manuc Bei has played an important role in the Romanian history, as he led negotiations with the Russians in 1808 to conclude peace, which was signed in the end just inside the inn he built in Bucharest. The Armenian merchant Manuc was even called "prince of Moldavia" on September 28, 1808, but he never got to actually be handled this function because of the Russo-Turkish War (1806-1812) (Giurescu 2009).

But, as stated above, the most pleasant memories of Bucharest about this Armenian are given by the famous Armenian Tavern's Inn today that delights the eyes of the locals and visitors. An interesting and also intriguing description was given by lonescu-Gion. He wrote in his history dedicated to Bucharest that "the inn (...) in Bucharest was one of the most visited inns between 1808 and 1860. Manuc inn yard was memorable for the noise, dirt and crowd of carriages that were in it. Many travelers, who descended from the inn, however, came to see it because of its picturesque courtyard and the superimposed pillars of the chambers" (Ionescu-Gion 2003: 493494). I was saying that the foregoing description is intriguing, because, currently, the inn is a place where tourists come from everywhere, but for lunch, to taste the spirit of Bucharest, and to admire the nice local, where noise, dirt and carriages were in the past, and not for the picturesque athmosphere mentioned by lonescu-Gion. Manuc Inn's is today an urban area that is full of history, a sight not to be missed and always present in all tourist guides, located in the proximity of the Old Court Palace. In other words, the centre of Bucharest comprises an important glimpse of Armenian culture.

Everything we have mentioned above answers the question addressed by Tunbridge (1994), who claims that cultural heritage is defined by two fundamental aspects. The first refers to the value of objectives that constitute or are considered cultural heritage, and the second concerns the interpretation of the outstanding components. In accordance with the issues raised by it, the Armenian church, the Armenian Street, Manuc's Inn, the Melik House (which houses the Theodor Pallady Museum) and the Zambaccian Museum are today of definite cultural value (Table 1). One more argument is that the cultural event called the Armenian Street Festival

The most important components of the Armenian cultural heritage

Table 1

\begin{tabular}{|l|c|l|c|}
\hline Name & Type & Description & Year \\
\hline $\begin{array}{l}\text { The Armenian } \\
\text { Church }\end{array}$ & architectural & $\begin{array}{l}\text { It was first built with wood and then made of } \\
\text { stone }\end{array}$ & 1638 \\
\hline $\begin{array}{l}\text { Armenian } \\
\text { Street }\end{array}$ & toponymic & $\begin{array}{l}\text { It is the expression of space markings in the } \\
\text { current city of the former Armenian slum once } \\
\text { outside the city gate }\end{array}$ & - \\
\hline Melik House & architectural & $\begin{array}{l}\text { It is one of the oldest houses in Bucharest and } \\
\text { it displays the museum dedicated to the painter } \\
\text { Theodor Pallady }\end{array}$ & 1770 \\
\hline Manuc's Inn & architectural & $\begin{array}{l}\text { The best-preserved old inn in Bucharest, } \\
\text { located in the historic center. Unlike previous } \\
\text { objectives, it is not in the area of the former } \\
\text { slum }\end{array}$ & 1808 \\
\hline $\begin{array}{l}\text { Zambaccian } \\
\text { Museum }\end{array}$ & architectural & $\begin{array}{l}\text { Located outside the former slum, the museum } \\
\text { bears the mark of the Armenian collector and } \\
\text { critic Krikor H. Zambaccian }\end{array}$ & 1940 \\
\hline $\begin{array}{l}\text { The Armenian } \\
\text { Street Festival }\end{array}$ & $\begin{array}{l}\text { cultural } \\
\text { festival }\end{array}$ & $\begin{array}{l}\text { An event meant to keep the memory of the } \\
\text { Armenian community alive, which is } \\
\text { happening in the homonymous street }\end{array}$ & 2017 \\
\hline
\end{tabular}


(Vișan 2017), which attracts many tourists, takes place annually in the perimeter of the former slum, marked on the map of Bucharest in Google Maps by the phrase " the Armenian neighborhood". Thus, the former neighborhood is, on the one hand, a true 'segregated landscape of the past', as Byrne (2003) said about the spaces marked by racism, and, on the other hand, an urban architectural gain. Bucharest, whose cosmopolitan history is well-known, can use this cultural heritage for tourism purposes, as suggested by Caffyn and Lutz (1999), and because, as Jackson (2010) points out, formerly segregated communities will always remain a subject of marketing the heritage identity and a key cultural resource.

\section{Conclusions}

The present paper highlights the long history of establishing the Armenians in the current space of Romania. Using historic sources, I placed the discussion about the Armenian community in an evolutionary context, exploring and, at the same time, pointing out precisely the moment of the arrival of the first Armenians in Bucharest and the manner in which they were received and treated. The purpose of their coming is a pragmatic one: the practice of their occupation, i.e. trade. The privileged religious relationship that the Romanians in Wallachia had with the Greeks and the Slavs, from whose holy books they were inspired and in whose languages the services were held in the churches of Bucharest, led to a discriminatory behavior towards the Armenians. Because they were practicing a different form of Orthodoxy, the Armenians were treated as second-hand inhabitants, and they were even called heretics and schismatics. In addition, the quasi-hermetic nature of the community, especially linguistic and confessional, generated the antipathy of the people living in Bucharest. Thus, the result of the first years of cohabitation materialized in the Armenians' obligation to locate their homes and to build their neighbourhood outside the city. They have never questioned their chasing away, as they were an important source of income for the administration, and they were taxed like those who lived in the city. In terms of socio-urban geography, this is geographic segregation determined by religious factors and, therefore, it is religious segregation.

Because the Armenian relationship with the native inhabitants was built on religious divergences as a way of cohabitation from the beginning, the research focused on highlighting the process of urban segregation. The corroboration of the specialized literature with the Bucharest case study strengthens the definite purpose of the research, as one observes that urban segregation on ethnic and religious grounds involves cultural elements. The research information has shown that ethno-religious segregation influences the urban landscape and, conversely, the urban landscape thus altered creates the premises for a particular type of cultural manifestation, and Bucharest is no exception to this principle. Moreover, the article argues and supports the idea that there is a striking resemblance between the segregation of the Armenians in Bucharest and that of the Jews in the European cities of the Middle Ages, especially Frankfurt am Main.

By the end of the eighteenth century, when Bucharest had expanded sufficiently to incorporate the Armenian slum, one can not speak of assimilation, although the relations may have improved to a substantial extent. It is certain that the passage of time has diminished the dissensions and it created an ever-increasing openness from both religious communities. In fact, the urban dynamics and the constraint of no longer being separated was the main force of change in behavior, and the Armenian slum has been transformed into an indissoluble part of Bucharest and a real urban landmark. The gradual decrease of interest in the ethnic, linguistic and religious character of the Armenians, together with the emergence of mixed marriages, was another major cause of the assimilation process. Once the two conditions were met, the need and historical reality of the Armenian space concentration disappeared. The data in the article validates the hypothesis that, in the middle of the last century, the Armenians were already spatially scattered to the point where we can find them in new neighborhoods, such as Dămăroaia, located in the outskirts of the city. 
Having all this in mind, we have been able to ascertain, and this is the most important conclusion of this article, that religious segregation, viewed temporally and evolutionary, is not always similar to an urban disease, but rather, it can be transformed into cultural heritage. The Bucharest case study strengthens this conclusion by pointing out how the old slum outside the city gate is today an organic part of the urban, architectural and cultural landscape. And equally true is that the cultural heritage of religious segregation is a valuable subject of patrimonial identity and a key cultural resource. Nevertheless, there remains at least one question to which further studies will have to answer, namely, how solid the link between segregation, in general, and cultural memory or social memory of once segregated spaces is. As such, further studies, starting from this analytical model, could investigate whether other forms of social and / or geographical segregation encountered in many cities around the world have highlighted the specific cultural landscape and how valuable this is for the urban environment. Moreover, greater attention may be paid to elements that differ from those identified in this study and which certainly can make a substantial contribution to the theory and literature of the relationship between segregation and culture.

\section{References}

ADAIR A. S., BERRY J. N., MCGREAL W. S. J., MURTAGH B., PARIS C. (2000), The local housing system in Craigavon, N. Ireland: ethno-religious residential segregation, sociotenurial polarisation and sub-markets, Urban Studies 37 (7), 1079-1092.

AGBARIA A. K. (2018), The 'right' education in Israel: segregation, religious ethnonationalism, and depoliticized professionalism, Critical Studies in Education 59 (1), 18-34. AIRINEI VASILE I. (2016), Armenians in the History of Bucharest, as Reflected in the City Toponymic Heritage, SGEM Conference Proceedings 1, 3-8.

AKKARA A. (2000), Pakistan's Christians Demand End to 'Religious Apartheid' at Polls, Christianity Today, Retrieved from: https://www.christianitytoday.com. Bucharest.

ALBINETZ C. (2012), Identităţi în dialog: Armenia şi armenii din Transilvania, Ararat,

ANTONIAN E. (2011), La Chişinău Manuc Bey încă veghează, Ararat, Retrieved from: https://www.araratonline.com.

ATTFIELD R. (1970), Non-tentative religious beliefs and rationality, Sophia 9 (2), 16-21. BEINART W., DUBOW S. (eds.) (2013), Segregation and Apartheid in TwentiethCentury South Africa, Taylor and Francis, Abingdon.

BENNETT S. M. (1998), Self-Segregation: An Oxymoron in Black and White, in: Freeman K. (ed.), African American culture and heritage in higher education research and practice, Praeger, Westport, pp. 121-131.

BOHLAND J. R. (1982), Indian Residential Segregation in the Urban Southwest: 1970 and 1980, Social Science Quarterly 63, 749-761.

BOWEN G. A. (2009), Document Analysis as a Qualitative Research Method, Qualitative Research Journal 9 (2), 27-40.

BYRNE D. (2003), Segregated landscapes: The heritage of racial segregation in New South Wales, Historic Environment 17 (1), 13-17.

CAFFYN A., LUTZ J. (1999), Developing the heritage tourism product in multi-ethnic cities, Tourism Management 20 (2), 213-221.

CARR J. H., KUTTY N. K. (eds.) (2008), Segregation: the rising costs for America, Routledge, New York.

CASHMAN L. (2017), New label no progress: institutional racism and the persistent segregation of Romani students in the Czech Republic, Race Ethnicity and Education 20 (5), 595-608.

CHELCEA L., DRUȚĂ O. (2016), Zombie socialism and the rise of neoliberalism in postsocialist Central and Eastern Europe, Eurasian Geography and Economics 57 (4-5), 521-544.

CORVALAN A., VARGAS M. (2015), Segregation and conflict: An empirical 
analysis, Journal of Development Economics 116, 212-222.

DAMÉ F. (2007), Bucureştiul în 1906, Paralela 45, Bucharest.

DAMLUJI M. (2010), "Securing Democracy in Iraq": Sectarian Politics and Segregation

in Baghdad, 2003-2007, Traditional Dwellings and Settlements Review 21 (2), 71-87.

DAVIS M. (2006), Planet of Slums, Verso, London and New York.

DIRADURIAN E. (2002), Amintiri ale unei profesoare și directoare de la Școala

Armeană din București (1950-1955), Ararat, Bucharest.

DOMINA T. (2006), Brain drain and brain gain: Rising educational segregation in the

United States, 1940-2000, City \& Community 5 (4), 387-407.

DOW G. S. (1929), Society and its problems: an introduction to the principles of sociology, Thomas Y. Crowell Company, New York.

EGNER F. S. (2016), Armeni botoşăneni în Armata Română, Ria, Botoşani.

ENACHE G. (2011), Biserica Apostolică Armeană, între sfâşiere şi unitate, Ziarul Lumina, Retrieved from: https://ziarullumina.ro.

EPSTEIN A., KHEIMETS N. (2000), Immigrant intelligentsia and its second generation: Cultural segregation as a road to social integration?, Journal of International Migration and Integration 1 (4), 461-476.

EVANS I. L. (1934), Native policy in southern Africa: an outline, Cambridge University

Press, Cambridge.

FLINT J. (2010), Faith and Housing in England: Promoting Community Cohesion or

Contributing to Urban Segregation?, Journal of Ethnic and Migration Studies 36 (2), 257-274. FLORESCU G. (2008), Confesiunile unui cafegiu, Humanitas, Bucharest.

FREEMAN L. (1999), A Note on the Influence of African Heritage on Segregation: The

Case of Dominicans, Urban Affairs Review 35 (1), 137-146.

FUCHS A., KROBB F. (eds.) (1999), Ghetto writing: traditional and Eastern Jewry in

German-Jewish literature from Heine to Hilsenrath, Camden House, Columbia.

GALE R. (2013), Religious residential segregation and internal migration: The British

Muslim case, Environment and Planning A: Economy and Space 45 (4), 872-891.

GAMBO Y. L., OMIRIN M. M. (2012), Ethno religious conflict and settlement pattern in

Northern Nigeria, Mediterranean Journal of Social Sciences 3 (3), 129-135.

GAZDOVITS N. (1996), Istoria armenilor din Transilvania: de la începuturi, până la

1900, Ararat, Bucharest.

GIURESCU C. C. (2009), Istoria Bucureştilor, Vremea, Bucharest.

GLASZE G. (2006), The spread of private guarded neighbourhoods in Lebanon and the significance of a historically and geographically specific governamentality, in: Glasze G., Webster C., Frantz K. (eds.), Private Cities: global and local perspectives, Routledge, New York, pp. 127-141.

TAMMARU T., MARCIŃCZAK S., VAN HAM M., MUSTERD S. (eds.) (2016), Socioeconomic segregation in European capital cities: East meets West, Routledge, Abingdon.

HARRISON B. (1972), Education, training, and the urban ghetto, The Johns Hopkins University Press, Baltimore.

HAYERN AYSOR (2013), International conference dedicated to Romanian-Armenian cultural heritage, Retrieved from: http://hayernaysor.am.

HOFFMANN C. (2008), From Heinrich Heine to Isidor Kracauer: The Frankfurt Ghetto in German-Jewish Historical Culture and Historiography, Jewish Culture and History 10 (2-3), 4564.

HOLDEN A. (2009), Religious Cohesion in Times of Conflict: Christian-Muslim Relations in Segregated Towns, Continuum International Publishing Group, London and New York. HSIA R. P.-C., LEHMANN H. (eds.) (1995), In and out of the Ghetto: Jewish-Gentile

Relations in Late Medieval and Early Modern Germany, Cambridge University Press, Cambridge.

HUTCHISON R., HAYNES B. D. (eds.) (2018), The ghetto: contemporary global issues and controversies, Routledge, New York. 
Viorel MIONEL

IONESCU-GION G. (2003), Istoria Bucurescilor, Tehnopress, laşi.

IORGA N. (1913), Armenii şi românii: o paralelă istorică, Analele Academiei Române 2 (1), 1-38

IORGA N. (2008), Istoria Bucureştilor, Vremea, Bucharest.

IRELAND P. (2008), Comparing responses to ethnic segregation in urban Europe, Urban Studies 45 (7), 1333-1358.

ISAAC R. K. (2009), Alternative Tourism: Can the Segregation Wall in Bethlehem be a Tourist Attraction?, Tourism and Hospitality Planning \& Development 6 (3), 247-254.

JACKSON A. (2010), Changing Ideas About Heritage and Heritage Resource Management in Historically Segregated Communities, Transforming Anthropology 18 (1), 80 92.

JEAMGOCIAN E. (2015), Catedrala armeană din Bucureşti, Ararat, Bucharest.

JENCKS C., PETERSON P. E. (eds.) (2001), The Urban underclass, Brookings Institution Press, Washington.

JOHNSTON R., POULSEN M., FORREST J. (2007), The Geography of Ethnic Residential Segregation: A Comparative Study of Five Countries, Annals of the Association of American Geographers 97 (4), 713-738.

KEENE D., NAGY B., SZENDE K. (eds.) (2016), Segregation - integration assimilation: religious and ethnic groups in the medieval towns of Central and Eastern Europe, Routledge, London.

KIPPING M., WADHWANI R. D., BUCHELI M. (2015), Analyzing and Interpreting Historical Sources: A Basic Methodology, in: Wadhwani R. D., Bucheli M. (eds.), Organizations in Time: History, Theory, Methods, Oxford University Press, Oxford.

KNOX H. M. (1973), Religious Segregation in the Schools of Northen Ireland, British Journal of Educational Studies 21 (3), 307-312.

LATHAM A., MCCORMACK D. P. (2004), Moving cities: rethinking the materialities of urban geographies, Progress in Human Geography 28 (6), 701-724.

MAJURU A. (2008), Bucureştii mahalalelor sau periferia ca mod de existenţă, Compania, Bucharest.

MÁLOVICS G., CRETAN R., MÉREINÉ BERKI B., TÓTH J. (2019), Urban Roma, segregation and place attachment in Szeged, Hungary, Area 51 (1), 72-83.

MARCUS R. D., BURNER D. (1936), The American Scene. Varieties of American History, Appleton-Century-Crofts, New York.

MASSEY D. S. (1990), American Apartheid: Segregation and the Making of the Underclass, American Journal of Sociology 96 (2), 329-357.

MASSEY D. S., DENTON N. A. (2003), American apartheid: segregation and the making of the underclass, Harvard University Press, Cambridge.

MCKEOWN S. A. (2012), The micro-ecology of religious segregation in Northern Ireland, University of Ulster, Coleraine.

MÉREINÉ BERKI B., MÁLOVICS G., TÓTH J., CREȚAN R. (2017), The role of social capital and interpersonal relations in the alleviation of extreme poverty and spatial segregation of Romani people in Szeged, Journal of Urban and Regional Analysis 9 (1), 33-50. Bucharest. MIHĂILESCU V. (2003), Evoluţia geografică a unui oraş - Bucureşti, Paideia, Bucharest.

MIONEL V. (2012), Segregarea urbană. Separaţi dar împreună, University Press,

MIONEL V. (2013), România ghetourilor urbane: spaţiul vicios al marginalizării, sărăciei şi stigmatului, Pro Universitaria, Bucharest.

MIONEL V., NEGUT S. (2011), The socio-spatial dimension of the Bucharest ghettos, Transylvanian Review of Administrative Sciences 33 E, 197-217.

MORGAN B. S. (1975), The Segregation of Socio-economic Groups in Urban Areas: A Comparative Analysis, Urban Studies 12 (1), 47-60.

MURTAGH B. (2011), Ethno-Religious Segregation in Post-Conflict Belfast, Built 
Environment 37 (2), 213-225.

MUSIL R. (1995), The man without qualities, Picador, London.

MYRDAL G., BOK S. (1944), An American dilemma: The Negro problem and modern democracy, Transactions Publishers, New Brunswick.

NARODOWSKI M., NORES M. (2002), Socio-economic Segregation with (without) Competitive Education Policies. A Comparative Analysis of Argentina and Chile, Comparative Education 38 (4), 429-451.

NATIONAL INSTITUTE OF STATISTICS (2012), Recensământul populației și al locuintelor 2011: Populația stabilă după etnie - județe, municipii, orașe, comune, Retrieved from: http://www.recensamantromania.ro.

NICOLAE I., SUDITU B. A., ENICĂ-PETRESCU S. (2006), Toponimie geografică, Meronia, Bucharest.

NORGREN J., NANDA S. (2006), American cultural pluralism and law, Praeger, Westport and London.

O'NIONS H. (2010), Different and unequal: the educational segregation of Roma pupils in Europe, Intercultural Education 21 (1), 1-13. ORĂŞANU A. M. (2003), Cum erau odinioară Bucureştii (V), Biblioteca Bucureștilor 5

PAUDICE A. (2014), Religious Identity and Space in Venetian Candia: Segregation within Colonization, in: Tolan J. V., Boissellier S. (ed.), Religious cohabitation in European towns (10th-15th centuries), Brepols, Turnhout, pp. 91-107.

PEACH C. (1975), Urban social segregation, Longman, London.

PHILLIPS D. (2006), Parallel lives? Challenging discourses of British Muslim selfsegregation', Environment and Planning D: Society and Space 24 (1), 25-40.

RABINOWITZ H. N. (1994), Race, ethnicity, and urbanization: selected essays, Universiy of Missouri Press, Columbia.

SANDELOWSKI M. (2008), Reading, writing and systematic review, Journal of Advanced Nursing 64 (1), 104-110.

SEDRA P. (1999), Class cleavages and ethnic conflict: Coptic Christian communities in modern Egyptian politics, Islam and Christian-Muslim Relations 10 (2), 219-235.

SHIRLOW P. (2016), Belfast: a segregated city, in: Coulter C., Murray M. (eds.),

Northern Ireland after the troubles: A society in transition, Manchester University Press, Manchester, pp. 73-87.

SMITH A. (2001), Religious Segregation and the Emergence of Integrated Schools in Northern Ireland, Oxford Review of Education 27 (4), 559-575.

SOLZHENITSYN A. I. (2004), Două secole împreuna, Univers, Bucharest.

London.

STEBBINS R. A. (2001), Exploratory research in the social sciences, Sage Publications,

STEELE J. (2005), Today's Bosnia: a dependent, stifled, apartheid regime, The Guardian, Retrieved from: https://www.theguardian.com.

STOICA L., IONESCU-GHINEA N. (2005), Enciclopedia lăcaşurilor de cult din Bucureşti, vol. 1, Universalia, Bucharest.

ŞCHIOPU M. (2009), Armenii din România, în istorie şi astăzi. Interviu cu Paul Bogdan, preot al Bisericii Armeneşti, Dilema Veche 259, Retrieved from: https://dilemaveche.ro.

TELLES E. E. (2006), Race in another America: the significance of skin color in Brazil, Princeton University Press, Princeton.

TELLIS W. M. (1997), Application of a Case Study Methodology, The Qualitative Report 3 (3), 1-19.

10.

TERZIAN S. (2001), Figuri armene ale Bucureştiului, Biblioteca Bucureştilor 4 (10), 4-

TUNBRIDGE J. E. (1994), Whose heritage? Global problem, European nightmare, in: Ashworth G. J., Larkham P. J. (eds.), Building a new heritage: tourism, culture, and identity in the new Europe, Routledge, London and New York, pp. 123-134.

VIȘAN I. (2017), Începe Festivalul "Strada Armenească"; trei zile de concerte, dansuri și 
concursuri, Agerpres, Retrieved from: https://www.agerpres.ro.

VOSGANIAN V. (2009), Cartea şoaptelor, Polirom, Bucharest.

VOSGANIAN V. (2012), 6 ianuarie - Crăciunul la armeni! Şi, de asemenea, şi Boboteaza..., Retrieved from: http://vosganian.ro.

WACQUANT L. (2013), Urban Outcasts: A Comparative Sociology of Advanced Marginality, Wiley, Oxford York.

WAGNER W. (1976), Beverly Hills: inside the golden ghetto, Grosset \& Dunlap, New

WHITE M. J. (1983), The Measurement of Spatial Segregation, American Journal of Sociology 88 (5), 1008-1018.

WIEVIORKA M. (1994), Spaţiul rasismului, Humanitas, Bucharest.

WILSON W. J. (ed.) (1993), The Ghetto underclass: social science perspectives, Sage Publications, Newbury Park.

WIRTH L. (1928), The ghetto, Chicago III, University of Chicago Press, Chicago.

YIN R. K. (2017), Applications of case study research, Sage, Los Angeles.

24DASH (2007), London's neighbourhoods 'segregated by religion', Retrieved from: http://www.24dash.com.

Initial submission: 21.01.2019

Revised submission: 01.04.2019

Final acceptance: 10.05.2019

Correspondence: Tourism and Geography Department, Faculty of Business and Tourism Bucharest University of Economic Studies, 41 Dacia Blvd., Sector 1, 010415, Bucharest, Romania.

Email: viorel.mionel@rei.ase.ro 
Journal of Urban and Regional Analysis, vol. XI, 1, 2019, p. 87 - 102

\title{
EMPIRICAL ANALYSIS ON THE DETERMINANTS OF URBAN PARKS
}

\author{
Kenichi SHIMAMOTO \\ Konan University, Kobe, Japan
}

\begin{abstract}
Urban parks play an important role in enhancing the lifestyle of the community by providing functions which support the environment, safety, health and ell-being. This paper will examine what the determining factors are for the development of urban parks, taking into consideration the supply side and demand side factors and past conditions of urban parks. Japan prefecture level data between 2001 to 2014 will be applied to a panel data analysis. The results find that for the supply side factors, the share of gross production by the construction industry and the financial strength of the local government; and on the demand side factors, preference towards the environment, health and well-being, have impact on the urban park area per capita at a statistically significant level.
\end{abstract}

Key Words: urban parks, financial strength of local government, preference, share of gross production by construction industry.

\section{Introduction}

In recent years, with the growing awareness of the sustainable development concept, there is an increasing demand for the consideration of the environment, health and safety alongside economic development. Urban parks are considered to play an important role by providing such functions that support the environment, safety, health, recreation and landscape (Ministry of Land, Infrastructure, Transportation and Tourism - Japan 2018). These functions supported by urban parks are well documented. In their role as green space, they provide services as urban ecosystems which include human health and well-being benefits and ecological benefits (Tzoulas et al. 2007, Breuste et al. 2013, Sutton and Anderson 2016). Studies which focus on the health and recreation function that urban parks provide are extensive (Bedimo-Rung et al. 2005, Giles-Corti et al. 2005, Pretty et al. 2005, Maller et al. 2006, Cohen et al. 2007, Lee and Maheswaran 2011, Wolch et al. 2011). Akpinar et al. (2016) study the impact of urban green space has on mental and general health across the Washington State in the United States. This impact is also studied by Song et al. (2015), concerning the walks through urban parks in Chiba, Japan, while Takano et al. (2002) study the association with longevity. The relationship with mental health is examined in 9 cities in Sweden (Grahn and Stigsdotter 2010) and in Helsinki, Finland (Tyrväinen et al. 2014). The impact on obesity and stress is also examined for Denmark (Sick Nielsen and Bruun Hansen 2007). The association between the recreational physical activity and the access to urban green space is examined for Norwich in the United Kingdom (Hillsdon et al. 2006).

Urban parks have been observed to service the environment through the provision of cooler microclimates and the reduction of surface water runoff, which offers potential support for cities to adapt to climate change (Gill et al. 2007). For example, mitigating the heat island effects in the built environments (Vidrih and Medved 2013) are examined for the cities of Vancouver, Sacramento (Spronken-Smith and Oke 1998), Lisbon (Oliveira et al. 2011) and Nagoya (Hamada and Ohta 2010, Hamada et al. 2013). Other literatures related to the environment include research on the urban residents' preference to be in contact with nature including trees and sounds (Carles et al. 1999, Lee et al. 2008, Matsuoka and Kaplan 2008). Other functions supported by urban parks include safety, which has been studied especially in Asia in relation 
to urban parks' role to support disaster prevention and emergency evacuation (Amemiya 2003, Masuda 2003, Zhu et al. 2016). There is also research on the relationship between urban parks and communication in the community (Coley et al.1997, Kuo et al. 1998, Chiesura 2004, Walker 2004). The financial impacts of urban parks have been examined from a number of angles. There are studies on urban parks in relation to housing and land prices based on the hedonic pricing model for Castellón, Spain (Bengochea Morancho 2003), Boston (Tajima 2003), Aalborg, Denmark (Panduro and Lausted Veie 2013), Lodz, Poland (Czembrowski and Kronenberg 2016), Sapporo, Japan (Aikoh et al. 2008), and Tokyo (Komatsu 2008). The economic benefits of urban parks have also been examined based on the willingness to pay for park availability in Copenhagen (Panduro et al. 2018) and conservation in Spain (LópezMosquera et al. 2014).

Based on these necessities for urban parks such as their importance for public health, research has gone into reviewing the accessibility and how they may not be equitably distributed. They review the accessibility based on socio-demographics to understand any differences such as income or ethnicity (Byrne et al. 2009, Neckerman et al. 2009, McConnachie and Shackleton 2010, Wolch et al. 2014). Furthermore, access to green space such as urban parks is being recognized as an environmental justice issue (Dai 2011, Jennings et al. 2012).

Further to literatures on the role and impact of urban parks, usability has also been examined. For example, Byrne et al. (2009) find that accessibility is an important factor for the usage of urban parks. Giles-Corti et al. (2005) explain the impact that the distance to and the size of parks have on usage. Studies on the usability for parks in Japan also examine the distance and accessibility to the parks (Shimomura et al. 1995, Boku et al. 1998). In this way, the determining factors concerning the utilization of urban parks have been studied in past literatures. However, to the best of my knowledge, they do not cover the determining factors of the provision of urban parks. Hence, this paper will attempt to examine the determinants of the provision of urban parks to answer the question of how the development of urban parks are determined. Furthermore, it has been identified that the volume of public goods such as urban parks are determined by factors on both the supply side and the demand side. In other words, where the marginal cost on the supply side coincides with the marginal benefit on the demand side, it will provide the maximum net benefit to society and determine the supply of public goods $^{1}$. It also can be considered that the existing urban parks will influence the size of the current urban parks. For example, if there is a year with a greater number of urban parks created, then there may be restrictions in the following year or it may stimulate further development of urban parks. Hence, this paper will focus on the supply side and demand side factors in relation to the development of urban parks and the existing urban parks to examine the possible significant impacts that these factors may have on urban park development. Japan prefecture level data from 2001 to 2014 will be utilized in the panel data analysis.

The second section will explain the methodology and data applied to analyse the determining factors of the provision of urban parks. The third section explains the results and it provides discussions concerning the main observations. The fourth section, the conclusions, provides a summary and it suggests the policy implications drawn from the results in section three.

\section{Methodology}

Urban parks, as well as other public goods, are reliant on economic variables. Furthermore, the supply of public goods is considered to be determined by the marginal cost to the supply side and the marginal benefit to the demand side, which means that the urban park area per capita

1)Although a park cannot be considered a pure public good given that a problem of congestion can arise and it is not physically difficult to exclude people from it, this paper will refer to it as a public good (Del Saz Salazar and García Menendez 2007). 
could also be determined in this way. This paper will also assume in the model that the construction of past urban parks has influence over the construction of current urban parks. Taking these points into consideration, it would be appropriate to use a dynamic panel data for this analysis. In particular, this paper will attempt to apply the dynamic panel analysis using first -differences. The characteristic of this model is that if the regression is completed at the level, the lagged dependent variable will correlate with an error term from the individual effect and it will not achieve a consistent estimate. However, in the model, the dependent variable and the independent variable will take the difference and the generalized method of moments (GMM) will be applied as a solution. With the specification used in the dynamic panel data model, if a second-order serial correlation in disturbances term exists, then it will not be possible to apply it as an instrumental variable. Then, the GMM estimator will not be a consistent estimator and a bias will occur. Hence, the Arellano-Bond test will be applied and it will examine whether the null hypothesis, which is the non-existence of the second-order serial correlation in disturbances, is rejected (Kitamura 2005, Uchiyama 2007, Chigira et al. 2011). Before conducting the above analysis, when the panel data is non-stationary, there is the risk of the spurious regression and so the dependent variables and all other independent variables used are examined using the Im-Pesaran-Shin and Fisher type panel unit root test and the stationarity of the data will be confirmed.

Next, we will review the variables used in this paper to understand the possible determinants of establishing urban parks.

\section{State Dependence (Parkt-1)}

As explained in the previous section, there is the possibility of state dependence on the urban parks. In other words, the construction of past urban parks could impact the construction of current urban parks. This paper takes into consideration this factor in the model.

\section{Share of Gross Production by the Construction Industry $(C P)$}

To represent an influential factor on the supply side, the share of gross production by construction industry for each region is adopted as an independent variable. The main supplier of public goods such as urban parks are construction companies, so it can be considered that they will have some influence over the provision of urban parks. For example, if construction companies have equal preference and capability to supply all public goods, a larger share of construction companies would mean a relatively larger amount of supply. Hence, the cost of constructing urban parks would be lower which could lead to an increase in urban parks. However, if there is stronger preference and/or capability of providing roads and other public facilities as public goods, then the supply of urban parks could decrease. In this way, the sign of the share of gross production of the construction industry could be positive or negative against the urban park area per capita. The construction industry's share of gross production is determined by the share of gross production by the construction industry by prefecture.

\section{Financial Strength}

Another supply side factor adopted as an independent variable is the financial strength of the local government since the local government finances the provision of urban parks. The net balance ratio $(N B R)$ will be used as the indicator of financial strength. The higher the amount of the actual expenditure rate means a healthy and stable financial operation which could be considered to have the capacity to fund the provision of urban parks. However, a prefecture with a large and positive NBR may prioritize projects with an explicit and high return on investment. Hence, investment in areas that struggle to quantify the benefits such as urban parks may not be a priority. In other words, the sign of the independent variable could be positive or negative. Depending on the objective or size of the urban park, the responsibility is 
shared between the prefecture and municipality. Most small parks fall under the responsibility of the municipality, but a large park that covers the area outside of one municipality will fall under the prefecture. Hence, the NBR is employed by calculating the weighted average of the $N B R$ for each prefecture and for each village/town/city with the corresponding expenditure.

\section{Preference and Prioritization of Urban Parks}

The provision of urban parks can also be influenced by demand. As mentioned in the earlier section, urban parks can have various positive effects on the environment, health, well-being and safety. This paper will examine how the demand of such functions that the urban parks provide can influence the development of urban parks. The prefecture level data that will be used as proxies to measure the demand of these functions are the municipal solid waste per capita, the number of hospitals per capita and the number of new subscriptions to fire insurance per capita.

The high production of municipal solid waste per capita (WASTE) could impact the ecosystem and create environmental issues such as dioxin from waste incineration and health concerns such as endocrine disruptor. Hence, a strong interest over the environment, health and wellbeing could lead to a demand of urban parks that can provide a positive impact in these areas. Thus, a positive sign can be expected from the independent variables.

Next, concerning the number of hospitals per capita for each prefecture (MED), a high MED could imply a high interest in health issues. A health-conscious prefecture could lead to a demand in the development of urban parks that could have a positive impact on health and well -being. On the other hand, the high penetration of hospitals could reduce the value of urban parks that support a healthy lifestyle and, as a result, the provision of urban parks could be limited. In other words, hospitals and urban parks could be in a substitute relationship. Therefore, the independent variable could show a positive or negative sign.

Concerning the number of new fire insurance subscribers per capita by prefecture (FIS), a larger number of subscribers could be considered as a higher interest in disaster prevention, safety concerns and well-being. Hence, this could lead to a stronger demand for urban parks which perform functions to support safety, disaster prevention and well-being. However, a large FIS could also weaken the need of such functions that urban parks provide and lead to a limited provision of urban parks. Like the MED case, FIS could be in a substitute relationship with urban parks. Hence, both positive and negative signs may be present with this variable.

Urban parks are also considered to provide important functions to support culture and strengthen communities, but prefecture level data that can be used as a proxy could not be identified. Prefecture level data to directly represent the preference concerning the environment, health, well-being and safety does not exist to the best of my knowledge. Under these data restrictions, the three indicators identified above, WASTE, MED and FIS, will be applied as proxies for these preferences $(P R E)$ in the analysis. All the variables are expressed in natural logarithms. The applied area and period for these variables are the 47 prefectures of Japan (Appendix 1) between the fiscal years of 2001 to 2014 . The data sources for the variables are provided in Appendix 2.

The basic model concerning the determinants of the urban park area per capita is provided below:

$$
\Delta \operatorname{Park}_{i t}=\alpha+\delta \Delta \operatorname{Park}_{i t-1}+\beta_{1} \Delta C P R_{i t}+\beta_{2} \Delta N B R_{i t}+\beta_{3} \Delta P R E_{i t}+\gamma_{i}+\Delta \varepsilon_{i t}
$$

The basic model above, takes heteroskedasticity into consideration. $\gamma_{i}$ of equation (1) 
represents the individual effects, ${ }^{\varepsilon_{i t}}$ the effort term. $\Delta$ represents the first difference.

\section{Results and Discussion}

Before we examine the basic model, the panel unit root test will be conducted on the dependent variables and all independent variables to ensure that the data is stationary. The ImPesaran-Shin panel unit root test, which is based on the mean of the individual Dickey-Fuller tstatistics of each unit in the panel, and the Fisher-type test which conducts unit root tests for each panel individually, are conducted to confirm whether the first differences of the above variables are stationary. This examination is useful for general observation. In the results achieved from these examinations (Table 1, Table 2), the corresponding p-values are essentially zero, so the existence of the unit root for all dependent variables and independent variables are rejected and it confirms that the data overall are stationary. If the second-order serial correlation in disturbances exists, then it may not be possible to apply instrumental variables and bias will occur with the GMM estimates. Hence, the Arellano-Bond test is applied to examine whether the null hypothesis, which is the non-existence of the second-order serial correlation in disturbances, is rejected. As in the results in Table 3, the second-order serial correlation in disturbances is rejected. The results of this test confirm that the GMM estimates are consistent.

Table 1

Im-Pesaran-Shin Panel Unit Root Test on Dependent and Explanatory Variables

\begin{tabular}{l|l|l|l}
\hline Variables & & Statistics & p-value \\
\hline PARK & Z-t-tilde-bar & -14.1159 & 0.000 \\
\hline$C P$ & Z-t-tilde-bar & -10.2930 & 0.000 \\
\hline$N B R$ & Z-t-tilde-bar & -12.1109 & 0.000 \\
\hline WASTE & Z-t-tilde-bar & -8.9873 & 0.000 \\
\hline$M E D$ & Z-t-tilde-bar & -10.4300 & 0.000 \\
\hline FIS & Z-t-tilde-bar & -9.4018 & 0.000 \\
\hline
\end{tabular}

Each independent variable will be examined based on these results. First, one of the supply side determinants, $C P$, indicates a positive sign in all models. This supports the suggestion that if the $C P$ with equal preference and capability to supply all public goods are greater, the contribution towards the supply of urban parks will be greater. However, only Model (2) achieves a statistically significant level. The other supply side determining factor, financial strength, the $N B R$, displays a significant negative sign for all models. This implies that when the $N B R$ is positive and greater, the prefecture may prioritize investment in areas other than urban parks. The investment may be in areas with a clearer return on investment which would be difficult to quantify with urban parks. 
Fisher Type Panel Unit Root Test on Dependent and Explanatory Variables

\begin{tabular}{|c|c|c|c|}
\hline Variables & & Statistics & p-value \\
\hline PARK & $\begin{array}{l}\text { Inverse chi-squared (94) } \quad \mathrm{P} \\
\text { Inverse normal } \quad \mathrm{Z} \\
\text { Inverse logit } \mathrm{t}(239) \quad \mathrm{L}^{*} \\
\text { Modified inverse chi-squared Pm }\end{array}$ & $\begin{array}{r}1426.2312 \\
-32.5630 \\
-57.4632 \\
97.1629\end{array}$ & $\begin{array}{l}0.000 \\
0.000 \\
0.000 \\
0.000\end{array}$ \\
\hline$\overline{C P}$ & $\begin{array}{l}\text { Inverse chi-squared (94) } P \\
\text { Inverse normal } \quad \mathrm{Z} \\
\text { Inverse logit t (239) } \mathrm{L}^{*} \\
\text { Modified inverse chi-squared Pm }\end{array}$ & $\begin{array}{r}529.1345 \\
-17.1402 \\
-21.1138 \\
31.7354\end{array}$ & $\begin{array}{l}0.000 \\
0.000 \\
0.000 \\
0.000\end{array}$ \\
\hline NBR & $\begin{array}{l}\text { Inverse chi-squared (94) } \quad \mathrm{P} \\
\text { Inverse normal } \quad \mathrm{Z} \\
\text { Inverse logit t (239) } \quad \mathrm{L}^{*} \\
\text { Modified inverse chi-squared Pm }\end{array}$ & $\begin{array}{r}852.5149 \\
-23.4001 \\
-34.2945 \\
55.3204\end{array}$ & $\begin{array}{l}0.000 \\
0.000 \\
0.000 \\
0.000\end{array}$ \\
\hline WASTE & $\begin{array}{l}\text { Inverse chi-squared (94) P } \\
\text { Inverse normal } \quad \mathrm{Z} \\
\text { Inverse logit t (239) } \quad \mathrm{L}^{*} \\
\text { Modified inverse chi-squared Pm }\end{array}$ & $\begin{array}{r}409.0198 \\
-13.5714 \\
-16.0958 \\
22.9752\end{array}$ & $\begin{array}{l}0.000 \\
0.000 \\
0.000 \\
0.000\end{array}$ \\
\hline$M E D$ & $\begin{array}{l}\text { Inverse chi-squared (94) } \mathrm{P} \\
\text { Inverse normal } \quad \mathrm{Z} \\
\text { Inverse logit t (239) } \quad \mathrm{L}^{*} \\
\text { Modified inverse chi-squared Pm }\end{array}$ & $\begin{array}{r}566.3459 \\
-17.3067 \\
-22.5318 \\
34.4494 \\
\end{array}$ & $\begin{array}{l}0.000 \\
0.000 \\
0.000 \\
0.000\end{array}$ \\
\hline FIS & $\begin{array}{l}\text { Inverse chi-squared (94) } P \\
\text { Inverse normal } \quad \mathrm{Z} \\
\text { Inverse logit } \mathrm{t}(239) \quad \mathrm{L}^{*} \\
\text { Modified inverse chi-squared Pm }\end{array}$ & $\begin{array}{r}336.9024 \\
-13.1034 \\
-13.4637 \\
17.7155\end{array}$ & $\begin{array}{l}0.000 \\
0.000 \\
0.000 \\
0.000\end{array}$ \\
\hline
\end{tabular}

Basic Models

Table 3

\begin{tabular}{l|ccc}
\hline \multirow{2}{*}{ Variables } & \multicolumn{3}{|c}{ Models } \\
\cline { 2 - 4 } PARKt-1 & (1) & (2) & (3) \\
& 0.0186 & 0.0728 & 0.1080 \\
CP & $(0.0896)$ & $(0.0789)$ & $(0.0770)$ \\
\hline NBR & 0.0142 & $0.0181^{*}$ & 0.0176 \\
& $(0.0100)$ & $(0.0106)$ & $(0.0113)$ \\
\hline WASTE & $-0.0165^{* *}$ & $-0.0242^{* * *}$ & $-0.0291^{* * *}$ \\
& $(0.0081)$ & $(0.0080)$ & $(0.0089)$ \\
\hline MED & $0.1130^{* * *}$ & & \\
& $(0.0359)$ & & \\
\hline FIS & \multicolumn{3}{|c}{$0.0969^{*}$} \\
& & $(0.0548)$ & -0.0004 \\
\hline
\end{tabular}


Empirical Analysis on the Determinants of Urban Parks

\begin{tabular}{l|ccc}
\hline Constant & $\begin{array}{c}0.1790^{* * *} \\
(0.0511)\end{array}$ & $\begin{array}{c}0.9990^{*} \\
(0.5130)\end{array}$ & $\begin{array}{c}0.0803 \\
(0.0523)\end{array}$ \\
\hline Wald test & 33.9800 & 20.1800 & 16.5000 \\
& $(0.0000)$ & $(0.0050)$ & $(0.0240)$ \\
\hline Arellano-Bond test(2) & -0.5988 & -0.2775 & 0.0431 \\
& $(0.5493)$ & $(0.7814)$ & $(0.9657)$ \\
\hline Observations & 564 & 564 & 564 \\
\hline
\end{tabular}

Robust standard errors in parentheses

${ }^{* * *} p<0.01,{ }^{* *} p<0.05,{ }^{*} p<0.1$

Model (1): WASTE is the proxy for PRE

Model (2): MED is the proxy for PRE

Model (3): FIS is the proxy for PRE

Concerning the demand side determinant, WASTE, which is one of the proxies to represent the preference concerning the environment and health which are supported by urban parks, indicates a significant positive sign. This suggests that higher WASTE may provide greater exposure to environmental and health issues, creating a much stronger demand for urban parks which support these needs. Next, the MED, which is applied as a proxy for healthconsciousness, shows a significant positive sign. As mentioned in the previous section, this could suggest that the regions with greater MED could be exposed to greater health issues and a greater awareness of the function that urban parks play in supporting healthy lifestyles and as a result have greater urban parks. Concerning the FIS, the proxy applied to represent the preference concerning disaster prevention, safety and well-being, shows that prefectures with high FIS have greater urban park area per capita. The greater awareness of safety and emergency may be reflected in the development of urban parks. Like the MED case, FIS and urban parks are not found to be in a substitute relationship as it was originally anticipated. However, there is a need to note that the results in Model (3) do not meet a significant standard. The size of the urban parks a year prior, which represents the previous state, displays positive impacts in all the models, but it does not reach a significant standard.

All the independent variables have been treated as exogenous variables in the analysis, but there is the need to consider the possibility of the variables being endogenous. If we examine this possibility for each variable, concerning the $N B R$, if the provision of urban parks reduces the available commercial, industrial or residential space, effecting the tax revenue, this would impact the NBR. Concerning the $C P$, the provision of urban parks, in turn, may stimulate the investment in public works and it may increase the $C P$. The provision of urban parks could also increase the awareness of environment and health, which could in turn reduce WASTE, which is applied as a proxy for environment, health, well-being and safety. A similar impact may occur with the other proxies, MED and FIS. In this way, the independent variable may not only be a determining factor for the size of urban parks, but also the result, which would support the possibility of endogeneity. Hence, the endogeneity will need to be considered when examining the relationship between urban parks and the independent variables.

As in the previous case where independent variables were treated as exogenous variables, the Arellano-Bond test rejected the second-order serial correlation in disturbances and all the models are accepted by model specification. Hence, we will first examine the case where one of the independent variables is endogenous.

As indicated in Table 4, the signs in all models are the same as in the case where all 
Models with One Endogenous Variable

\begin{tabular}{|c|c|c|c|c|c|c|c|c|c|}
\hline & \multicolumn{9}{|c|}{ Model } \\
\hline & (4) & (5) & (6) & (7) & (8) & (9) & (10) & $(11)$ & $(12)$ \\
\hline \multirow{4}{*}{$\frac{P A R K t-1}{C P}$} & 0.0356 & 0.0554 & 0.0791 & 0.0195 & 0.0546 & 0.0978 & \begin{tabular}{|l|l|}
0.02877 \\
\end{tabular} & 0.0460 & 0.0653 \\
\hline & $(0.0761)$ & $(0.0738)$ & $(0.0739)$ & $(0.0946)$ & $(0.0873)$ & $(0.0873)$ & $(0.0678)$ & $(0.0734)$ & $(0.0704)$ \\
\hline & 0.0138 & 0.0181 & $0.0234^{* *}$ & 0.0157 & $0.0215^{* *}$ & $0.0243^{\star \star}$ & $0.0171^{*}$ & 0.0148 & $0.0264^{* * *}$ \\
\hline & $(0.009)$ & $(0.011)$ & $(0.0113)$ & $(0.0102)$ & $(0.0108)$ & $(0.0110)$ & $(0.0094)$ & $(0.0097)$ & $(0.0096)$ \\
\hline \multirow{4}{*}{$\frac{N B R}{\text { WASTE }}$} & $-0.0154^{*}$ & $-0.0256^{* * *}$ & $-0.0351^{* * *}$ & -0.0095 & -0.0144 & -0.0250 & $-0.0205^{\star \star}$ & $-0.0157^{\star \star}$ & $-0.0368^{* * *}$ \\
\hline & $(0.0092)$ & $(0.0084)$ & $(0.0108)$ & $(0.0136)$ & $(0.0156)$ & $(0.0173)$ & \begin{tabular}{|l|}
$(0.0086)$ \\
\end{tabular} & $(0.0077)$ & $(0.0096)$ \\
\hline & $0.1030^{* * *}$ & & & $0.1220^{* * *}$ & & & $0.0911^{* \star *}$ & & \\
\hline & $(0.0313)$ & & & $(0.0330)$ & & & $(0.0199)$ & & \\
\hline \multirow[t]{2}{*}{$M E D$} & & $0.1170^{\star \star *}$ & & & $0.1580^{* * *}$ & & & $0.2110^{\star * \star}$ & \\
\hline & & $(0.0448)$ & & & $(0.0544)$ & & & $(0.0488)$ & \\
\hline \multirow[b]{2}{*}{ FIS } & & & 0.0012 & & & 0.0014 & & & 0.0038 \\
\hline & & & $(0.0075)$ & & & $(0.0073)$ & & & $(0.0071)$ \\
\hline \multirow[t]{2}{*}{ Constant } & $0.1670^{* * *}$ & $1.1950^{* * *}$ & $0.1070^{* *}$ & $0.1880^{* * *}$ & $1.5810^{* * *}$ & $0.1040^{* *}$ & $0.1670^{* \star \star}$ & $2.0660^{\star \star \star}$ & $0.1270^{* * \star}$ \\
\hline & $(0.0440)$ & $(0.4160)$ & $(0.0514)$ & $(0.0492)$ & $(0.5030)$ & $(0.0482)$ & $(0.0300)$ & $(0.4570)$ & $(0.0397)$ \\
\hline \multirow{2}{*}{$\begin{array}{l}\text { Wald test } \\
\text { (Prob. > } \\
\text { chi2) } \\
\end{array}$} & 33.2800 & 23.2100 & 17.0500 & 30.8700 & 23.0800 & 12.2800 & 45.7 & 35.4700 & 23.7100 \\
\hline & $(0.0000)$ & $(0.0001)$ & $(0.0019)$ & $(0.0000)$ & $(0.0001)$ & $(0.0154)$ & $(0.0000)$ & $(0.0000)$ & $(0.0001)$ \\
\hline $\begin{array}{l}\text { A-B test } \\
(2)^{\star \star \star \star}\end{array}$ & -0.4647 & -0.4126 & -0.2631 & -0.5697 & -0.4015 & -0.0559 & -0.6277 & -0.4453 & -0.4168 \\
\hline $\begin{array}{l}\text { (Prob. }> \\
\mathrm{z} \text { ) }\end{array}$ & $(0.6422)$ & (0.6799) & $(0.7925)$ & $(0.5689)$ & (0.6881) & $(0.9554)$ & $(0.5302)$ & $(0.6561)$ & $(0.6768)$ \\
\hline $\mathrm{N}^{* * * * *}$ & 564 & 564 & 564 & 564 & 564 & 564 & 564 & 564 & 564 \\
\hline
\end{tabular}

Robust standard errors in parentheses

${ }^{* * *} p<0.01,{ }^{* *} p<0.05,{ }^{*} p<0.1$

$* * * *$ Arellano-Bond test $(2)$

$* * * * *$ number of observations

Model (4): only CP is endogenous; WASTE is the proxy for PRE

Model (5): only CP is endogenous; MED is the proxy for PRE

Model (6): only CP is endogenous FIS is the proxy for PRE

Model (7): only NBR is endogenous; WASTE is the proxy for PRE

Model (8): only NBR is endogenous; MED is the proxy for PRE

Model (9): only NBR is endogenous; FIS is the proxy for PRE

Model (10): only WASTE is endogenous

Model (11): only MED is endogenous

Model (12): only FIS is endogenous

independent variables were applied as exogenous variables. In particular, significant positive signs are identified in Models (6), (8), (9), (10) and (12) for the supply side factor, $C P$. Models (4), (5), (6), (10), (11) and (12) confirm significant negative results for NBR which are consistent with the previous results where all independent variables are treated as exogenous. Concerning the demand side factors, the results for WASTE show significant positive results against the urban park area per capita in Models (4), (7) and (10); MED results display significant positive coefficients in Models (5), (8) and (11); and the FIS results are positive signs, but they do not meet a significant level as in the previous case with the exogenous variables. But, the results for the area size of urban parks one year earlier, which describe the 
previous situations, indicate that all models show positive impacts, but they do not reach significant levels, which is consistent with the exogenous variable case.

Next, we will examine the case where there are 2 endogenous variables. The results in Table 5 are consistent with the previous case where there was one endogenous variable. Concerning the supply side determinants, Models (13), (14), (15), (16), (18), (19) and (21) find $C P$ showing significant positive results and NBR displaying significant negative results in Models (16), (17), (18) and (21). On the demand side, the results for WASTE in Models (13), (16) and (19) are significantly positive as well as the results for MED in Models (14), (17) and

Models with Two Endogenous Variables

Table 5

\begin{tabular}{|c|c|c|c|c|c|c|c|c|c|}
\hline & \multicolumn{9}{|c|}{ Model } \\
\hline & (13) & (14) & (15) & (16) & (17) & (18) & (19) & (20) & (21) \\
\hline \multirow[t]{2}{*}{ PARKt-1 } & 0.0415 & 0.0551 & 0.0857 & 0.0437 & 0.0467 & 0.0757 & 0.0291 & 0.0452 & 0.0714 \\
\hline & $(0.0758)$ & $(0.0734)$ & $(0.0772)$ & $(0.0713)$ & $(0.0749)$ & $(0.0723)$ & $(0.0682)$ & $(0.0734)$ & $(0.0757)$ \\
\hline \multirow[t]{2}{*}{$C P$} & $0.0162^{\star}$ & $0.0200^{\star \star}$ & $0.0284^{\star \star \star}$ & $0.0206^{\star \star}$ & 0.0152 & $0.0274^{\star \star \star}$ & $0.0175^{\star}$ & 0.0148 & $0.0274^{\star \star \star}$ \\
\hline & $(0.0087)$ & $(0.0102)$ & $(0.0096)$ & $(0.0084)$ & $(0.0096)$ & $(0.0096)$ & $(0.0094)$ & $(0.0095)$ & $(0.0094)$ \\
\hline \multirow[t]{2}{*}{ NBR } & -0.0044 & -0.0121 & -0.0258 & $-0.0156^{\star}$ & $-0.0153^{\star}$ & $-0.0311^{\star \star \star}$ & -0.0122 & -0.0035 & $-0.0308^{*}$ \\
\hline & $(0.0087)$ & $(0.0124)$ & $(0.0159)$ & $(0.0085)$ & $(0.0087)$ & $(0.0110)$ & $(0.0110)$ & $(0.0092)$ & $(0.0168)$ \\
\hline \multirow[t]{2}{*}{ WASTE } & $0.1130^{\star \star \star}$ & & & $0.0817^{\star \star \star}$ & & & $0.1020^{\star \star \star}$ & & \\
\hline & $(0.0301)$ & & & $(0.0183)$ & & & $(0.0194)$ & & \\
\hline \multirow[t]{2}{*}{$M E D$} & & $0.1660^{\star \star \star}$ & & & $0.2020^{\star \star \star}$ & & & $0.2620^{\star \star \star}$ & \\
\hline & & $(0.0494)$ & & & $(0.0488)$ & & & $(0.0547)$ & \\
\hline \multirow[t]{2}{*}{ FIS } & & & 0.0039 & & & 0.0004 & & & 0.0044 \\
\hline & & & $(0.0072)$ & & & $(0.0073)$ & & & $(0.0076)$ \\
\hline \multirow[t]{2}{*}{ Constant } & $0.1770^{\star \star \star}$ & $1.6530^{\star \star \star}$ & $0.1260^{\star \star \star}$ & $0.1650^{\star \star \star}$ & $1.9830^{\star \star \star}$ & $0.1130^{\star \star}$ & $0.1750^{\star \star \star}$ & $2.5410^{\star \star \star}$ & $0.1280^{\star \star \star}$ \\
\hline & $(0.0409)$ & $(0.4540)$ & $(0.0426)$ & $(0.0297)$ & $(0.4560)$ & $(0.0441)$ & $(0.0288)$ & $(0.5090)$ & $(0.0394)$ \\
\hline Wald test & 46.3000 & 34.6500 & 19.3700 & 51.6400 & 36.2600 & 17.3500 & 31.8900 & 32.9300 & 18.0900 \\
\hline $\begin{array}{l}\text { (Prob. > } \\
\text { chi2) }\end{array}$ & $(0.0000)$ & $(0.0000)$ & $(0.0007)$ & $(0.0000)$ & $(0.0000)$ & $(0.0017)$ & $(0.0000)$ & $(0.0000)$ & $(0.0012)$ \\
\hline $\begin{array}{l}\text { A-B test } \\
(2)^{\star \star \star \star \star}\end{array}$ & -0.4515 & -0.4314 & -0.2992 & -0.5941 & -0.3943 & -0.3344 & -0.3793 & -0.3635 & -0.1715 \\
\hline (Prob. > z) & $(0.6516)$ & $(0.6662)$ & $(0.7648)$ & $(0.5525)$ & $(0.6934)$ & $(0.7381)$ & $(0.7045)$ & $(0.7163)$ & $(0.8638)$ \\
\hline $\mathrm{N}^{\star \star \star \star \star \star}$ & 564 & 564 & 564 & 564 & 564 & 564 & 564 & 564 & 564 \\
\hline
\end{tabular}

Robust standard errors in parentheses

${ }^{* * *} p<0.01,{ }^{* *} p<0.05,{ }^{*} p<0.1$

$* * * \star$ Arellano-Bond test (2)

$\star * * * *$ number of observations

Model (13): CP and NBR are endogenous; WASTE is the proxy for PRE

Model (14): CP and NBR are endogenous; MED is the proxy for PRE

Model (15): CP and NBR are endogenous; FIS is the proxy for PRE

Model (16): CP and WASTE are endogenous

Model (17): CP and MED are endogenous

Model (18): CP and FIS are endogenous

Model (19): NBR and WASTE is endogenous

Model (20): NBR and MED is endogenous

Model (21): NBR and FIS is endogenous 
(20). However, the signs for FIS show a consistent trend, but not at a significant level. As in the previous cases, the previous year shows a positive relationship against the current urban park area per capita in all models, but not at a significant level.

Finally, we will observe the case where all the independent variables are exogenous. As displayed in Table 6 , the results in all models support the same sign as in the previous exogenous cases. Concerning the supply side factor, in Model (22) and (24), the CP show positive and significant results and the NBR displays negative and significant results. On the demand side, WASTE displays a positive and significant result in Model (22) and the MED shows a significant positive impact in Model (23). FIS, though showing a consistent sign, is not at a statistically significant level. The urban park area in the previous year compared to the current year shows a positive relationship in all models, but not at a significant level.

From these results, we learn that, in all reviewed cases which include independent variables

Models with All Endogenous Variable

Table 6

\begin{tabular}{|l|c|c|c|}
\hline & \multicolumn{3}{|c|}{ Model } \\
\cline { 2 - 4 } Variables & $(\mathbf{2 2})$ & $(\mathbf{2 3})$ & $(\mathbf{2 4})$ \\
\hline PARKt-1 & 0.0436 & 0.0444 & 0.0782 \\
\hline CP & $(0.0717)$ & $(0.0748)$ & $(0.0765)$ \\
\hline NBR & $0.0208^{\star \star}$ & 0.0149 & $0.0273^{\star \star}$ \\
& $(0.0085)$ & $(0.0094)$ & $(0.0097)$ \\
\hline WASTE & -0.0101 & -0.0032 & $-0.0279^{\star}$ \\
\hline MED & $(0.0098)$ & $(0.0083)$ & $(0.0164)$ \\
\hline FIS & $0.0880^{\star \star \star}$ & & \\
& $(0.0169)$ & & \\
\hline Constant & & $0.2550^{\star \star \star}$ & \\
& & $(0.0533)$ & \\
\hline Wald test & & & 0.0009 \\
(Prob. > chi2) & & & $(0.0076)$ \\
\hline Arellano-Bond test(2) & -0.4287 & -0.3938 & -0.2589 \\
\hline (Prob. > z) & $(0.6682)$ & $(0.6937)$ & $(0.7957)$ \\
\hline Observations & 564 & 564 & 564 \\
\hline
\end{tabular}

Robust standard errors in parentheses

${ }^{* * *} p<0.01,{ }^{* *} p<0.05,{ }^{*} p<0.1$

Model (22): CP, NBR and WASTE is endogenous

Model (23): CP, NBR and MED is endogenous

Model (24): CP, NBR and FIS is endogenous

treated as exogenous and endogenous, for the supply side determinants, $C P$ displays significant positive results and the NBR shows significant negative results in most of the models. Considering that there is limited past research on the supply side factors that impact the provision of urban parks, the significant results concerning the impact that the construction industry has on urban parks is a unique find. Concerning economic influences, this paper has 
reviewed past literatures on the impact that urban parks have on housing prices, and they identified positive impacts (Bengochea Morancho 2003, Tajima 2003, Panduro and Lausted Veie 2013, Czembrowski and Kronenberg 2016). Literatures which studied the impact of urban parks in Japan on land prices were also positive (Aikoh et al. 2008, Komatsu 2008). However, these past literatures did not cover the impacts that the financial strength of the local governments have on the provision of urban parks which has been identified to have no positive impact on the development of urban parks in this study.

Concerning the demand side determinants, WASTE, the proxy for the environment and health which are functions supported by urban parks, shows significant positive results. The literatures reviewed previously on the impact that urban parks have on the environment also indicated positive impacts (Spronken-Smith and Oke 1998, Carles et al. 1999, Lee et al. 2008, Matsuoka and Kaplan 2008, Oliveira et al. 2011). Studies on urban parks in Japan also found positive impacts on the environment, through their cooling effects to counter global warming (Hamada and Ohta 2010, Hamada et al. 2013). The higher WASTE may provide greater exposure to environmental and health issues, creating a much stronger demand for urban parks, which in these past studies confirm a positive impact on the environment. The MED, the proxy employed for health consciousness, displays significant positive impacts on the urban park area per capita in all models. The literature reviewed in this paper on the impact of urban parks on health also indicated positive results including the studies on Japan (Takano et al. 2002, Sick Nielsen and Bruun Hansen 2007, Grahn and Stigsdotter 2010, Tyrväinen et al. 2014, Song et al. 2015, Akpinar et al. 2016). This suggests that health consciousness influences the development of urban parks and, in return, it has a positive impact on health and well-being.

Concerning the size of urban parks in the previous year, which describes the previous state, it was identified to have a positive relationship with urban park area per capita, but not at a statistically significant level.

Since the dependent variable and each independent variable are expressed in natural logarithms, the coefficient for each independent variable represents elasticity. Hence, the strength of the elasticity against the dependent variable, urban park area per capita for each independent variable can be compared. By observing the significant coefficients, we learn that on the supply side, the $C P$ indicates an elasticity between the range of 0.0162 to 0.0284 and the NBR, the financial indicator, a value of -0.0153 to -0.0368 . On the demand side, WASTE indicates 0.0817 to 0.122 and MED values between 0.0969 and 0.262 . Thus, the results indicate that the demand side factors have relatively greater elasticity compared to the supply side factors.

\section{Conclusions}

With the growing awareness on sustainable development, the occurrence of natural disasters and the increasing health consciousness, it is important to understand the determinants of the development of urban parks which are considered to have functions to support the environment, the health, safety and well-being of the population. The volume of public goods which include urban parks are determined by the supply side and demand side factors. This paper focuses on the supply side and demand side factors and the situation of past urban parks to observe if they have any significant impact on the development of urban parks. It effectively applies Japan prefecture level data from 2001 to 2014 in the panel data analysis.

The results find cases where the supply side factors, such as the $C P$ and $N B R$, and the demand side factors, which include preference concerning the environment, health and wellbeing, have statistically significant impact on the urban park area per capita. These results provide some policy implications. First, in a number of models, the financial strength indicator, $N B R$, displays a significant negative impact on the development of urban parks. This may be 
due to prefectures preferring to focus on areas with a clear return on investment. Hence, the development of urban parks with limited ability to quantify the benefits may become a lower priority. However, this may mean that if the benefits of urban parks could be quantified, under a solid financial operation, the cost of these benefits could be incorporated, leading to a more active development of urban parks. In this way, urban parks, a public good with limited ability to be valued in the market, could benefit from further analysis concerning the application and improvement of a number of evaluation methods such as the revealed preference approach and the stated preference approach in order to quantify the important functions which urban parks provide.

One of the main players in the development of urban parks is the construction industry. The $C P$ impact on the urban park area per capita is a significant positive one. However, the construction companies may focus heavily on construction projects other than urban parks such as economic infrastructure. Therefore, in order to avoid a bias towards economic infrastructure and to achieve a sustainable well-balanced supply of public goods, it may be necessary to educate the market and to introduce incentives.

The WASTE indicates some significantly positive impacts on urban park area per capita which has positive influence on the environment and health. In all models, the MED suggests healthconsciousness to have a significant impact on the development of urban parks. These results suggest that a strategy and execution plan on the development of the environment and health may be required to facilitate the development of urban parks. This could create the need for education, development and reinforcement of regulations. It may also indicate a need for urban parks to be designed and for facilities to be provided in order to support the environment and a healthy life-style. There may be cases where the preference for other goods and services could be in a substitute relationship with the preference for urban parks, so in order to facilitate the development of urban parks, it may be necessary to provide goods and services which are in a complementary relationship with urban parks.

The consideration of these suggested policies could facilitate the development of urban parks which provide important functions to the well-being of society through the improvement of the environment and the safety and health of the population. In turn, this could lead to the progress towards a sustainable society. 


\section{Prefectures of Japan}

Appendix 1

1 Hokkaido, 2 Aomori, 3 Iwate, 4 Miyagi, 5 Akita, 6 Yamagata, 7 Fukushima, 8 Ibaraki, 9 Tochigi, 10 Gunma, 11 Saitama, 12 Chiba, 13 Tokyo, 14 Kanagawa, 15 Niigata, 16 Toyama, 17 Ishikawa, 18 Fukui, 19 Yamanashi, 20 Nagano, 21 Gifu, 22 Shizuoka, 23 Aichi, 24 Mie, 25 Shiga, 26 Kyoto, 27 Osaka, 28 Hyogo, 29 Nara, 30 Wakayama, 31 Tottori, 32 Shimane, 33 Okayama, 34 Hiroshima, 35 Yamaguchi, 36 Tokushima, 37 Kagawa, 38 Ehime, 39 Kochi, 40 Fukuoka, 41 Saga, 42 Nagasaki, 43 Kumamoto, 44 Oita, 45 Miyazaki, 46 Kagoshima, 47 Okinawa

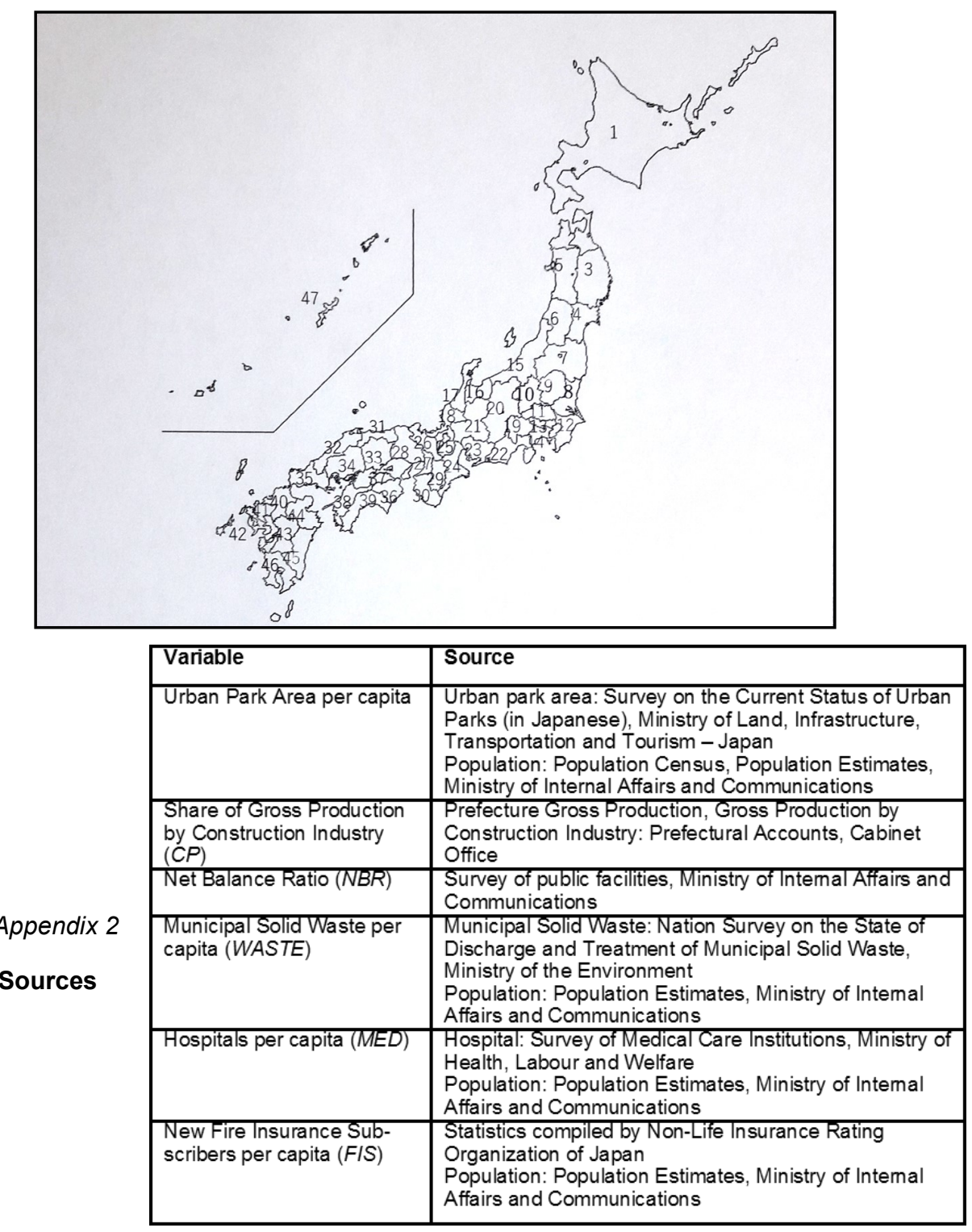




\section{References}

AIKOH T., SAKIYAMA N., SHOJI Y. (2008), Analysis of economic effect of green spaces on land price in residential areas by hedonic approach, Journal of The Japanese Institute of Landscape Architecture 71 (5), 727-730.

AMEMIYA M. (2003), A review of progress in park and open space safety research: towards a new planning theory, Journal of The Japanese Institute of Landscape Architecture 66 (3), 185-190.

AKPINAR A., BARBOSA-LEIKER C., BROOKS K. R. (2016), Do green space matter? Exploring relationships between green space type and health indicators, Urban Forestry \& Urban Greening 20, 407-418.

BEDIMO-RUNG A., MOWEN A. J., COHEN D. A. (2005), The significance of parks to physical activity and public health: A conceptual model, American Journal of Preventive Medicine 28 (2), 159-168.

BENGOCHEA MORANCHO A. (2003), A hedonic valuation of urban green areas, Landscape and Urban Planning 66 (1), 35-41.

BOKU E., TASHIRO Y., KINOSHITA T. (1998), A study on relation between the characteristics of park use of aged people and their access distance, Journal of The Japanese Institute of Landscape Architecture 65 (1), 781-784

BREUSTE J., QURESHI S., LI J. (2013), Scaling down the ecosystem services at local level for urban parks of three megacities, Hercynia N. F. 46, 1-20.

BYRNE J., WOLCH J., ZHANG J. (2009), Planning for environmental justice in urban national park, Journal of Environmental Planning and Management 52 (3), 365-392.

CARLES J. L., LÓPEZ BARRIO I., DE LUCIO J. V. (1999), Sound influence on landscape values, Landscape and Urban Planning 43 (4), 191-200.

CHIESURA A. (2004), The role of urban parks for the sustainable city, Landscape and Urban Planning 68 (1), 129-138.

CHIGIRA H., HAYKAWA K., YAMOAMOTO T. (2011), Dogakuteki panel data bunseki (Dynamic panel data analysis), Chisen Shokan, Tokyo.

COHEN D. A., MCKENZIE T. L., SEHGAL A., WILLIAMSON S., GOLINELLI D., LURIE

N. (2007), Contribution of Public Parks to Physical Activity, American Journal of Public Health 97 (3), 509-514.

COLEY R. L., SULLIVAN W. C., KUO F. E. (1997), Where Does Community Grow? The Social Context Created by Nature in Urban Public Housing, Environment and Behavior 29 (4), 468-494.

CZEMBROWSKI P., KRONENBERG J. (2016), Hedonic pricing and different urban green space types and sizes: Insights into the discussion on valuing ecosystem services, Landscape and Urban Planning 146, 11-19.

DAI D. (2011), Racial/ethnic and socioeconomic disparities in urban green space accessibility: Where to intervene?, Landscape and Urban Planning 102 (4), 234-244.

DEL SAZ SALAZAR S., GARCÍA MENENDEZ L. (2007), Estimating the non-market benefits of an urban park: Does proximity matter?, Land Use Policy 24 (1), 296-305.

GILES-CORTI B., BROOMHALL M. H., KNUIMAN M., COLLINS C., DOUGLAS K., NG K., LANGE A., DONOVAN R. J. (2005), Increasing walking: How important is distance to, attractiveness, and size of public open space?, American Journal of Preventative Medicine 28 (2), 169-176.

GILL S. E., HANDLEY J. F., ENNOS A. R., PAULEIT S. (2007), Adapting cities for climate change: the role of the green infrastructure, Built Environment 33 (1), 115-133.

GRAHN P., STIGSDOTTER U. K. (2010), The relation between perceived sensory dimensions of urban green space and stress restoration, Landscape and Urban Planning 94 (34), 264-275.

HAMADA S., OHTA T. (2010), Seasonal variations in the cooling effect of urban green areas on surrounding urban areas, Urban Forestry \& Urban Greening 9 (1), 15-24. 
HAMADA S., TANAKA T., OHTA T. (2013), Impacts of land use and topography on the cooling effect of green areas on surrounding urban areas, Urban Forestry \& Urban Greening 12 (4), 426-434.

HILLSDON M., PANTER J., FOSTER C., JONES A. (2006), The relationship between access and quality of urban green space with population physical activity, Public Health 120 (12), 1127-1132.

JENNINGS V., GAITHER C. J., SCHULTERBRANDT GRAGG R. S. (2012), Promoting Environmental Justice Through Urban Green Space Access: A Synopsis, Environmental Justice 5 (1), 1-7.

KITAMURA Y. (2005), Panel data analysis, Iwanami Shoten, Tokyo.

KOMATSU H. (2008), A study on land pricing structure of urban public parks in commercial areas, The Japanese Journal of Real Estate Sciences 21 (4), 103-114.

KUO F. E., SULLIVAN W. C., COLEY R. L., BRUNSON L. (1998), Fertile Ground for Community: Inner-City Neighborhood Common Spaces, American Journal of Community Psychology 26 (6), 823-851.

LEE A. C., MAHESWARAN R. (2011), The health benefits of urban green spaces: a review of the evidence, Journal of Public Health 33 (2), 212-222.

LEE S.-W., ELLIS C. D., KWEON B.-S., HONG S.-K. (2008), Relationship between landscape structure and neighborhood satisfaction in urbanized areas, Landscape and Urban Planning 85 (1), 60-70.

LÓPEZ-MOSQUERA N., GARCÍA T., BARRENA R. (2014), An extension of the Theory of Planned Behavior to predict willingness to pay for the conservation of an urban park, Journal of Environmental Management 135, 91-99.

MALLER C., TOWNSEND M., PRYOR A., BROWN P., ST LEGER L. (2006), Healthy nature healthy people: 'contact with nature' as an upstream health promotion intervention for populations, Health Promotion International 21 (1), 45-54.

MASUDA N. (2003), Urban park planning from the point of view of the safety and secure urban environment, Landscape Research Japan Online 66 (3), 180-184.

MATSUOKA R. H., KAPLAN R. (2008), People needs in the urban landscape: Analysis of Landscape and Urban Planning Contributions, Landscape and Urban Planning 84 (1), 7-19.

MCCONNACHIE M. M., SHACKLETON C. M. (2010), Public green space inequality in small towns in South Africa, Habitat International 34 (2), 244-248.

MINISTRY OF LAND, INFRASTRUCTURE, TRANSPORTATION AND TOURISM JAPAN (2018), Toshi-koen no yakuwari (The Role of Urban Parks), Retrieved from: http:// www.mlit.go.jp.

NECKERMAN K. M., LOVASI G. S., DAVIES S., PURCIEL M., QUINN J., FEDER E., RAGHUNATH N., WASSERMAN B., RUNDLE A. (2009), Disparities in Urban Neighborhood Conditions: Evidence from GIS Measure and Field Observation in New York City, Journal of Public Health Policy 30 (1), 264-285.

OLIVEIRA S., ANDRADE H., VAZ T. (2011), The cooling effect of green spaces as a contribution to the mitigation of urban heat: $A$ case study of Lisbon, Building and Environment 46 (11), 2186-2194.

PANDURO T. E., JENSEN C. U., HEDEMARK LUNDHEDE T., VON GRAEVENITZ K., JELLESMARK THORSENAB B. (2018), Eliciting preferences for urban parks, Regional Science and Urban Economics 73, 127-142.

PANDURO T. E., LAUSTED VEIE K. (2013), Classification and valuation of urban green spaces - A hedonic house price valuation, Landscape and Urban Planning 120, 119-128.

PRETTY J., PEACOCK J., SELLENS M., GRIFFIN M. (2005), The mental and physical health outcomes of green exercise, International Journal of Environmental Health Research 15 (5), 319-337.

SHIMOMURA Y., MASUDA N., ABE D., YAMAMOTO S., SUZUKI K. (1995), Study on residents' behavior of block park in neighborhood, Journal of the Japanese Institute of Landscape Architecture 58 (5), 217-220.

SICK NIELSEN T., BRUUN HANSEN K. (2007), Do green areas affect health? Results 
from a Danish survey on the use of green areas and health indicators, Health \& Place 13 (4), 839-850.

SONG C., IKEI H., IGARASHI M., TAKAGAKI M., MIYAZAKI Y. (2015), Physiological and psychological effects of a walk in urban parks in fall, International Journal of Environmental Research and Public Health 12 (11), 14216-14228.

SPRONKEN-SMITH R. A., OKE T. R. (1998), The thermal regime of urban parks in two cities with different summer climates, International Journal of Remote Sensing 19 (11), 20852104.

SUTTON P. C., ANDERSON S. J. (2016), Holistic valuation of urban ecosystem services in New York City's Central Park, Ecosystem Services 19, 87-91.

TAJIMA K. (2003), New Estimates of the Demand for Urban Green Space: Implications for Valuing the Environmental Benefits of Boston's Big Dig Project, Journal of Urban Affairs 25 (5), 641-655

TAKANO T., NAKAMURA K., WATANABE M. (2002), Urban residential environments and senior citizens' longevity in megacity areas: the importance of walkable green spaces, Journal of Epidemiology \& Community Health 56 (12), 913-918.

TYRVÄINEN L., OJALA A., KORPELA K., LANKI T., TSUNETSUGU Y., KAGAWA T. (2014), The influence of urban green environments on stress relief measures: $A$ field experiment, Journal of Environmental Psychology 38, 1-9.

TZOULAS K., KORPELA K., VENN S., YLI-PELKONEN V., KAŹMIERCZAK A., NIEMELA J., JAMES P. (2007), Promoting ecosystem and human health in urban areas using green infrastructure: A literature review, Landscape and Urban Planning 81 (3), 167-178.

UCHIYAMA K. (2007), $\mathrm{CO}_{2}$ Emission and the Environmental Kuznets Curve: Evidence from Dynamic Panel Data Estimation, Economics Today 27 (3).

VIDRIH B., MEDVED S. (2013), Multiparametric model of urban park cooling island, Urban Forestry \& Urban Greening 12 (2), 220-229. DC.

WALKER C. (2004), The public value of urban parks, The Urban Institute, Washington,

WOLCH J., JERRETT M., REYNOLDS K., MCCONNELL R., CHANGE R., DAHMANN N., BRADY K., GILLILAND F., SU J. G., BERHANE K. (2011), Childhood obesity and proximity to urban parks and recreational resources: A longitudinal cohort study, Health \& Place 17 (1), 207-214.

WOLCH J. R., BYRNE J., NEWELL J. P. (2014), Urban green space, public health, and environmental justice: The challenge of making cities 'just green enough', Landscape and Urban Planning 125, 234-244.

ZHU C., WANG Y., REN W., LUO I., YIN Y., XIE W., LIU W. (2016), The Planning of Green Spaces to Prevent and Avoid Urban Disasters in Dujiangyan, International Journal of Simulation - System, Science \& Technology 17 (46), 27.1-27.6.

Initial submission: 22.01.2019

Revised submission: 25.04.2019

Final acceptance: 30.05 .2019

Correspondence: Hirao School of Management, Konan University, 8-33

Takamatsucho, Nishinomiya, Hyōgo 663-8204, Japan.

Email: ken_japan51@hotmail.com 


\title{
BOOK REVIEWS
}

\section{LOWER DANUBE BASIN. APPROACHES TO MACROREGIONAL SUSTAINABILITY}

\author{
DAN BĂLTEANU (ed.), \\ The Publishing House of the Romanian Academy, Bucharest, 2017, 227 pp., \\ ISBN 978-973-27-2771-3 \\ Reviewed by AURELIAN GIUGĂL
University of Bucharest, Romania
}

\begin{abstract}
Contemporary society is facing two major umbrella, the chapter aims to explore and global phenomena. First of all, at a level never decipher the interaction between the human attained in all its previous history, Terra has society and the environment. In addition to the reached an unseen level of development applicative functions of such technologies, translated in prosperity, health and safety. these computer tools have facilitated Secondly, this socio-economic dynamics connections between researchers from comes with many environmental costs. In this different scientific areas with similar IT context, maintaining and advancing economic requirements (p.63). In order to scrutinize the progress is closely linked with the capacity of environment transformations, several tools are countries/regions to promote development applied in the four papers. They are models capable to address these particular represented by software programs, such as issues generated by our economic uptrend.

the Danubia or IMPACT2C web-atlas and the Global Atlas of the Danube Valley. With the The Danube basin (812 000 square help of these tools, the authors aim to provide kilometres) is part of the aforementioned accurate information on the dynamics of global process. It is the subject of important environmental changes due to human activity. transformations triggered by climate change, For example, the simulation system showed i.e. temperature increase, especially in the that the overflow in the Upper Danube basin summer and in the South-Eastern part of the will be reduced from $1450 \mathrm{~m}^{3} / \mathrm{s}$ to a value areal, and decreasing rainfall etc. The volume between 1000 and $1300 \mathrm{~m}^{3} / \mathrm{s}$ by the year Lower Danube Basin. Approaches to 2060. The low flow will have a negative impact Macroregional Sustainability (coordinated by on shipping, irrigation and aquatic ecosystems Dan Bălteanu) comes to respond to these along the Lower Danube (p. 22). In short, the contemporary challenges. It is based on the information is crucial for the decision-makers selective communications of the fourth edition and the researchers' scientific approaches that of the international symposium entitled: seek to provide information for the "Interdisciplinary Research-Innovation Related stakeholders.
\end{abstract} to the EU Strategy for the Danube Region".

The second chapter focuses on environmental The volume comprises three chapters. The impacts and biodiversity. The themes of the first chapter, "Global Change Context: articles are diverse, ranging from the impact of Transdisciplinary and Capacity Building", Danubius-RI (pan-European research includes four papers focused on toolkits, i.e. infrastructure) on hazard and risk maps high supercomputers, IT services, numerical alongside the Danube, to ecosystem services simulation tools, in relation to the climate in Romania and the migration and protection change context in the region. Under this of sturgeon. The first paper of this second 
chapter, entitled "Public Perceptions and Socio and resources. -Economic Analysis on the Impact of Danubius -Rl", is at least problematic. The first issue The last chapter of the volume, "Regional and comes from the selection of the participants, Local Perspectives of Territorial all of them being located in Tulcea County. So Development", is the most eclectic one. The that, the authors expected that out of 1067 constellation of subjects wanders through a respondents, many of them would be able to cross-sectorial collaboration in the Adriatic answer to the questions framed within the Danubian region, including tourism "International Centre for Advanced Studies for development in the lower Danube, the River - Sea Systems - DANUBIUS-RI". The Romanian Danube Valley economic evolution second issue targets the methodological (not surprisingly, deindustrialization, a postchoice, the authors deciding to collect the data communist economic process, has increased through computer assisted telephone poverty especially in small and medium-sized interview. The problem with this approach is towns), and a literature review of the research that it is somewhat counterproductive as carried out in the Danube area.

people are asked to speak about a technical project. Why did the authors not use the Revisiting the chapters, one asks himself in structured or semi-structured interviews, with the end what the volume is about. Of course, it the help of which the researchers would have represents an analysis of the Danube basin, had the opportunity to better interact, explain particularly the Lower Danube sector, as part the project, and understand the views of the of global processes, such as climate change, respondents? The authors do not clearly detail economic, population and technological the reasons (a more facile and comfortable dynamics. Attempting to explore the climate way?) of why they chose this interviewing transformations in the region, the volume uses method and how it addressed the a multitude of methods and it targets a whole development of the project. Furthermore, array of directions. Throughout informatics although the questionnaire contains eight software and statistical analyses, the questions and 44 items, only three questions interdisciplinary research provides the were taken in the authors' analysis: i) if stakeholders with overdetailed and mainly citizens have heard about the DANUBIUS-RI technical information about the nature of these project ("Have you heard about the developing changes (including the environmental ones) of of the DANUBIUS-RI?"); ii) which will be the our societies. However, how this information main three benefits resulted from the reaches to them and how it is transferred into implementation of the project ("What would be practice, remains to be seen. In short, by the main advantages obtained as a result of showing the problems of our neighbourhoods, the existence of the DANUBIUS-RI hub?"); the researchers are doing just half of this and iii) how important this project will be in complex job. It remains for the decisionterms of creating new jobs, attracting foreign makers, the national, regional or local public tourists to the area, attracting foreign investors authorities, to attempt to apply these analyses, to the region, and so on and so forth. Overall, research and findings when they define and the selected questions are rather vague, implement public policies, and when they superfluous, and not really worth anything. develop capabilities based on such solutions. Rather, it would have been interesting to Therefore, despite the many flaws that the analyse the problems these people are volume contains, its presence helps, struggling with. Simply said, to ask what nevertheless, as it is a useful volume for all people think about a technical project about those who want to overview the dynamics of which, taking into account the objective changes not only in the Danube basin, but reasons, they knew too little, is a waste of time also in our society in general. 


\section{Aims and scopes}

Analysis of the urban and regional condition needs to be interdisciplinary. In reality, urban researchers usually tend to belong to a discipline reflecting their training whether as sociologists, geographers, planners or any number of subjects concerned with the study of space and place. Our training very often endorses an appreciation of how other disciplines explore the city. For the journal the acknowledgement of the many disciplines that concerned with understanding cities and regions will be indicated by the different disciplinary back-grounds reflected in the papers published. Articles will be published by geographers, sociologists, planners, economists, political scientists, to mention just few of the disciplines involved in urban and regional study.

The Journal of Urban and Regional Analysis plans to be a key outlet publishing topical articles dealing with cities and regions. In later issues we plan to include sections devoted to notes and comments as well as a policy section outlining and discussing state and non-state initiatives aimed at improving cities and regions, together with the problems confronted by their implementation.

\section{Instructions to Authors}

1. The Journal of Urban and Regional Analysis seeks to redefine and revigorate the links between geography, sociology, planning, economy, political science. It aims to publish original academic research, critical studies and discussions of the highest scholar standard in the field of urban and regional development. Submitted papers will be evaluated on the basis of their creativity, academic quality and contributions to advancing understanding of the complex problems related to urban and regional development.

2. Submitted manuscripts must be original, unpublished contributions. They must not be submitted or accepted by any other publications. All articles submitted to the Journal will be available online, free of charge.

3. One electronic copy of the manuscript (sent by email in PDF format) should be submitted to either of the two Editors listed below.

\section{Ioan IANOS Ronan PADDISON}

University of Bucharest - University of Glasgow Interdisciplinary Centre for Department of Advanced Research on Geographical and Earth Territorial Dynamics, Sciences East Quadragle 030018, Bucharest, University Avenue, Romania 4-12, Regina Glasgow Elisabeta Blv. E-mail: office@cicadit.ro E-mail: Ronan.Paddison @ges.gla.ac.uk

4. Layout: Manuscripts should be written in English and contain no more than 8000 words. Page setup: A4 size, 3 $\mathrm{cm}$. all margins; title: Arial Bold, 12 pts, all caps, centered.; 2 empty rows (same font); name of authors using Arial, 10 pts.: first name italic, last name upper-case, centered. Affiliation follows below, centered; 2 empty rows (same
Font). The abstract: start with the word "Abstract", followed by the text, not to exceed 150 words. Use Arial, 8 pts., justified alignment, indent $2 \mathrm{~cm}$. left and right; 1 empty row, same font. Three or four keywords should start after the word "keywords", written using Arial, 8 pts., justified alignment, indent $2 \mathrm{~cm}$. to the left. Keywords should be written using Arial Italic, 8 pts.; 2 empty rows, same font. The text uses Arial, 9 pts., Justify alignment. Headings use Arial Bold, 9 pts., centered. Research articles should use the following headings: Introduction, Materials and Methods, Results and Discussion, Conclusions, References. The text of tables uses Arial, 9 pts. Captions and tiles of tables are centered and use Arial Bold, 9 pts. Tables and figures should be centered and numbered consecutively throughout the manuscript and referred in the text using Arab numbering. Captions should use the word table/figure with italic characters followed by the title with bold font. Citations in the text should use the Harvard System of short references, for example, (Geyer 2002) followed by $a, b, \ldots$ when two or more references to works by one author are given for the same year, e.g. (Geyer 2002a, 2002b). Page numbers should be indicated for quotations. At the end of the article, a full listing of references in alphabetical order should be provided in the following style; use Arial, 9 pts, hang at $1 \mathrm{~cm}$ :

GIDDENS A. (1990), The Consequences of Modernity, Polity Press, Cambridge. MARSHAL R. (1995), The global job crisis, Foreign Policy, 100, 50-68.

*** (1938-1941), General Romanian Population nd Settlements Census on December the 29th 1930, I-X, ICS, Bucharest.

Images should be submitted in their final form, both as good quality hard copy and electronically.

Authors not proficient in English should have their manuscripts checked before submission by a competent English speaker. To edit your manuscript, use the template available at www.jurareview.ro.

5. Paper submissions must be printed on one side of A4 or US Letter-sized paper, double spaced (including footnotes and references) with a 1.5 inches margin and numbered pages. Submissions will not be normally returned to authors. Avoid excessive use of footnotes. Tables and figures should be attached on separate pages the end of the manuscript and their approximate position indicated in the text.

6. Final versions of papers accepted for publishing should be submitted electronically in a MS Word compatible format suitable for editing.

7. The Journal of Urban and Regional Analysis also publishes reviews of selected books in the field of urban and regional development. Books should be sent for potential review by JURA to the University of Bucharest Interdisciplinary Centre for Advanced Research on Territorial Dynamics, 030018, Bucharest, Romania, 4-12, Regina Elisabeta Blv .

\section{Open-access journal}




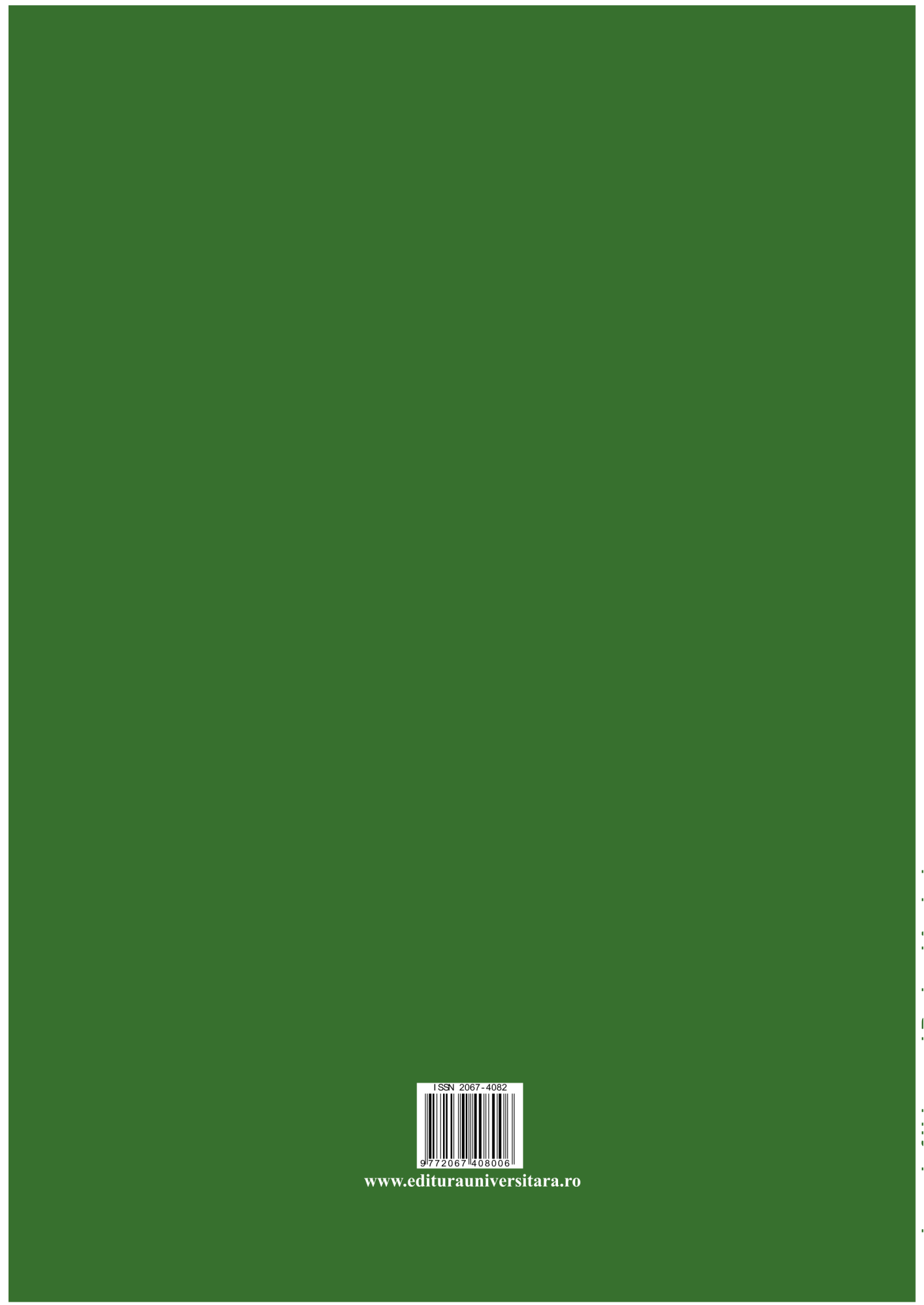

